INTER NATIONAL MONETARY FUND
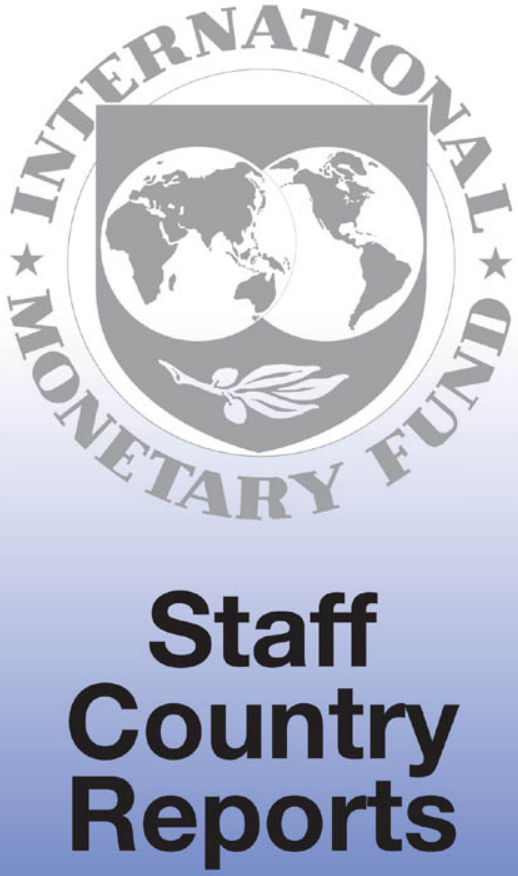
July 2000

IMF Staff Country Report No. 00/82

\section{Italy: Selected Issues}

This Selected Issues report on Italy was prepared by a staff team of the International Monetary Fund as background documentation for the periodic consuitation with this member country. As such, the views expressed in this document are those of the staff team and do not necessarily reflect the views of the Government of Italy or the Executive Board of the IMF.

Copies of this report are available to the public from

International Monetary Fund - Publication Services

700 19th Street, N.W. - Washington, D.C. 20431

Telephone: (202) 623-7430 - Telefax: (202) 623-7201

Telex (RCA): 248331 IMF UR

E-mail: publicationspimf-org

Internet: http://www.imf.org

Price: $\$ 15.00$ a copy

\section{International Monetary Fund \\ Washington, D.C.}




\section{INTERNATIONAL MONETARY FUND}

\section{ITALY}

\section{Selected Issues}

Prepared by a staff team consisting of Marco Annunziata, Jörg Decressin, and Ioannis Halikias (EU1), and István Székely (FAD)

Approved by the European I Department

May 19,2000

Contents

Page

Basic Data 5

Introduction and Overview 6

I. Puzzling Out Italy's Growth Performance ........................................................9

A. Demand-Side Developments............................................................10

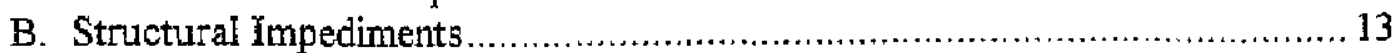

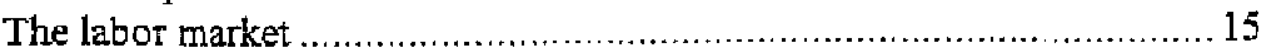

C. Concluding Remarks and Policy Implications ....................................25

Tables

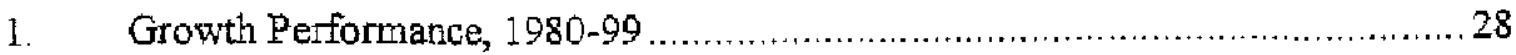

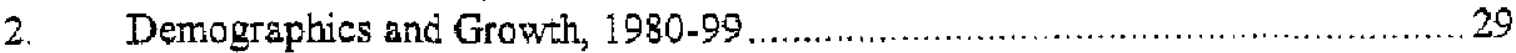

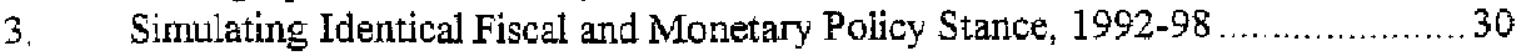

4. Decomposing Growth Differentials, 1992-98 ......................................... 31

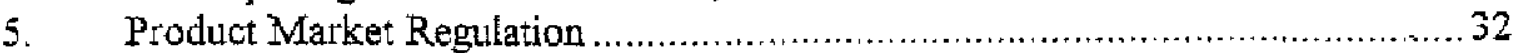

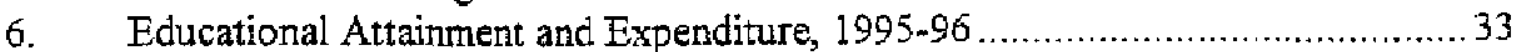

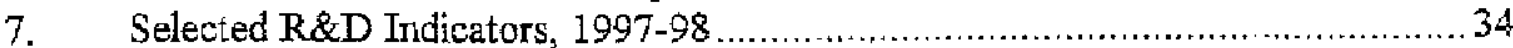

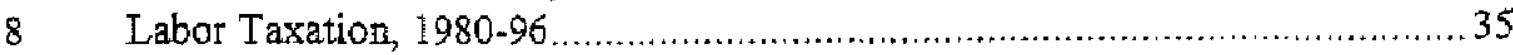

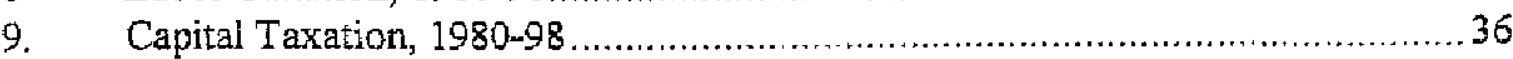

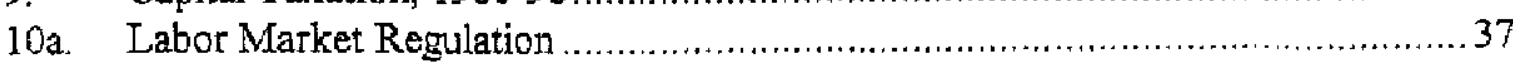

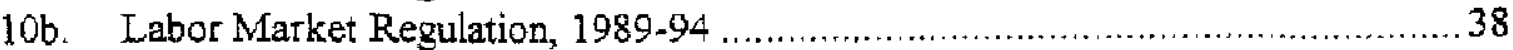

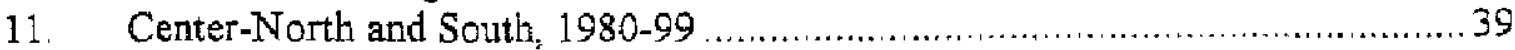

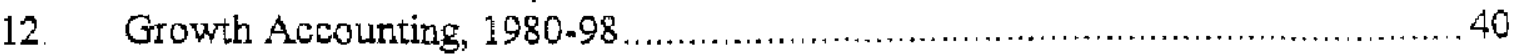

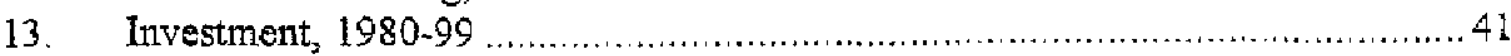

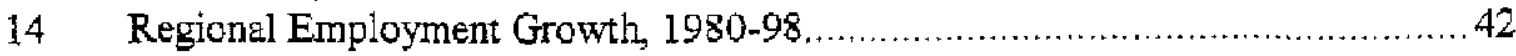

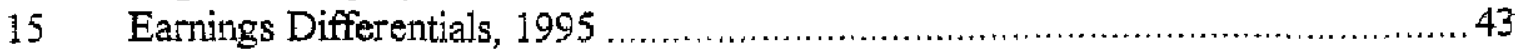

CInternational Monetary Fund. Not for Redistribution 
Figures

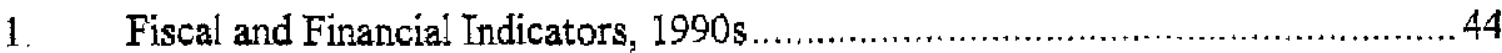

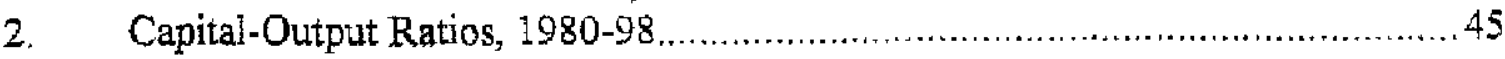

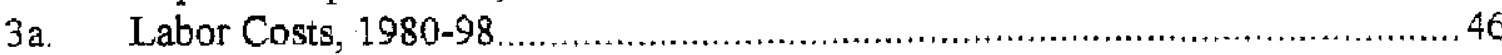

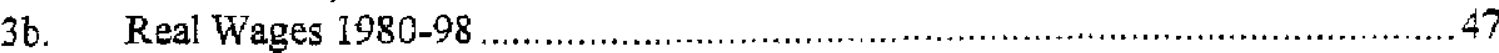

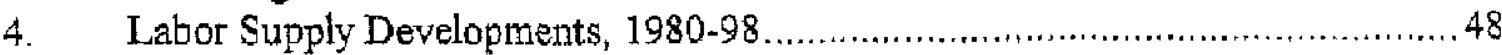

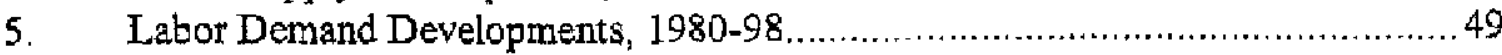

5. Regional Labor Demand and Supply Differences, $1980-98 \ldots \ldots \ldots \ldots \ldots \ldots \ldots \ldots \ldots . \ldots 50$

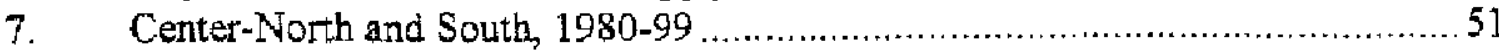

8. Regional Labor Demand and Supply, $1980-98 \ldots \ldots \ldots \ldots \ldots \ldots \ldots \ldots \ldots \ldots \ldots \ldots \ldots \ldots \ldots 2$

\section{Text Boxes}

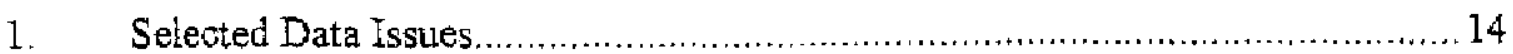

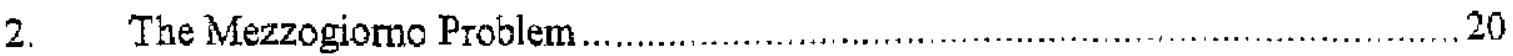

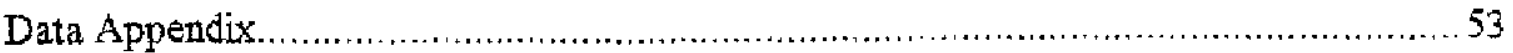

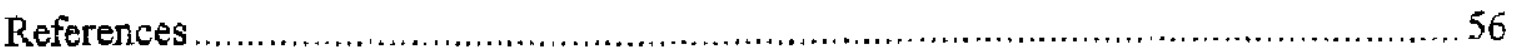

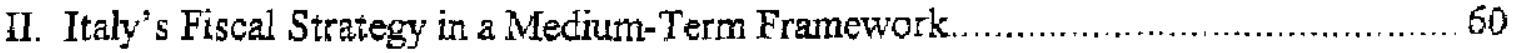

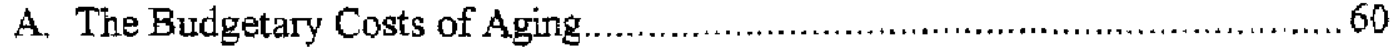

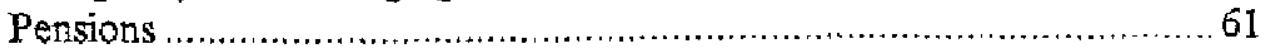

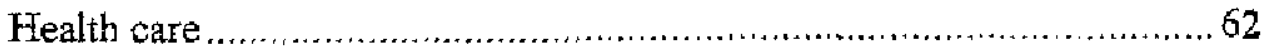

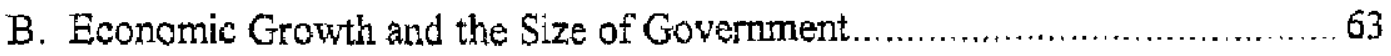

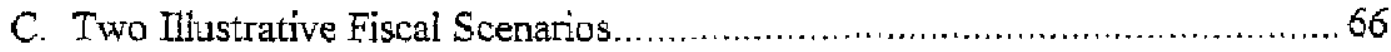

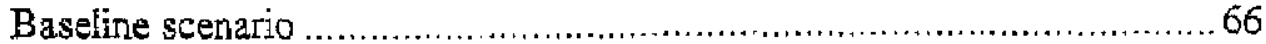

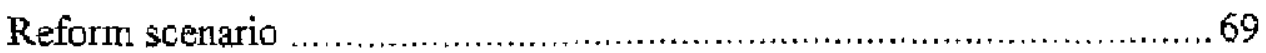

The impact of higher productivity growth $\ldots \ldots \ldots \ldots \ldots \ldots \ldots \ldots \ldots \ldots \ldots \ldots 71$

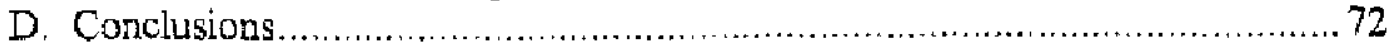

Tables

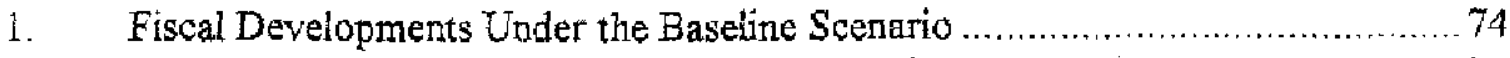

2. Fiscal Developments Under the Reform Scenario $\ldots \ldots \ldots \ldots \ldots \ldots \ldots \ldots \ldots \ldots \ldots \ldots \ldots 75$

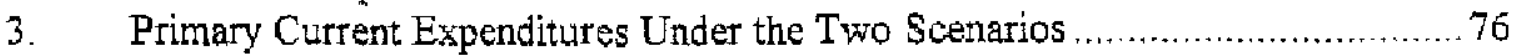

\section{Figures}

1. General Government Revenues, Expenditures, and Balance Under the Baseline Scenario, 2000-45. 
2. Debt and Revenue Dynamics Under Different Deficit Rules in the Baseline

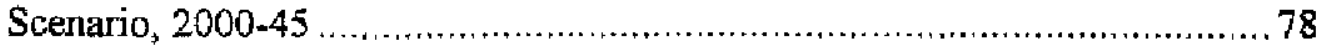

3. General Government Revenues, Expenditures, and Balances Under the Reform Scenario, 2000-45 .............................................................. 79

4. Revenues and Expenditures Under Different Scenarios and Productivity Growth Assumptions, 2000-45 ....................................................... 80 5. Public Debt, Revenues, and Primary Current Expenditures, 2000-45 ........... 81

References......

III. The Evolving Role of Regions in Italy: The Financing and Management of Health

Care Services. 84

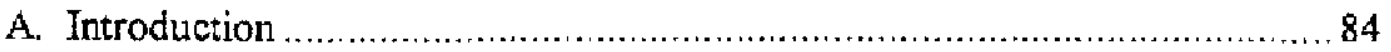

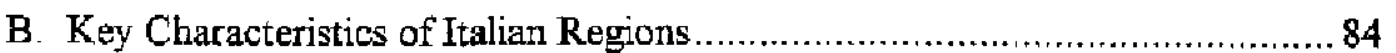

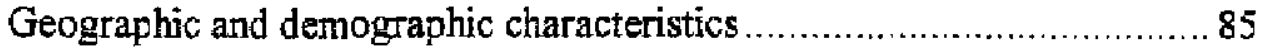

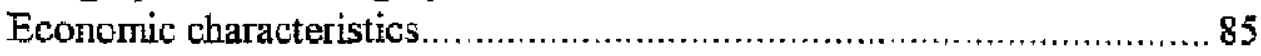

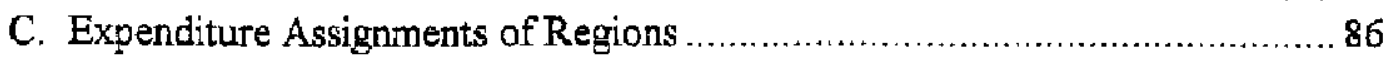

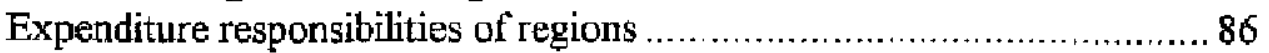

Overall trends in public expenditure at the subnational level ..............87

D. The Management and Financing of the Public Health Care System ............. 89

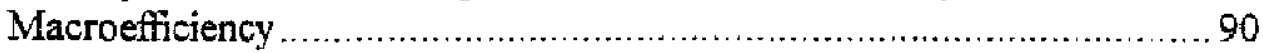

Macroefficiency and regional pattern of public health care expenditure... 91

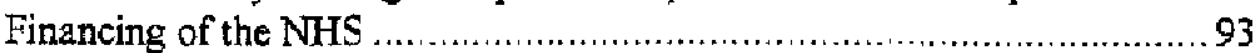

Potential problems of decentralization ........................................ 94

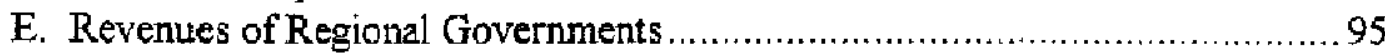

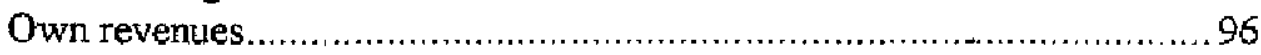

The new system of equalization $\ldots \ldots \ldots \ldots \ldots \ldots \ldots \ldots \ldots \ldots \ldots \ldots \ldots \ldots . \ldots 7$

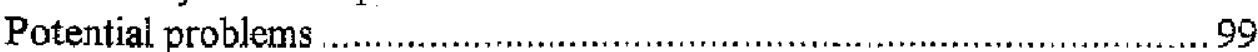

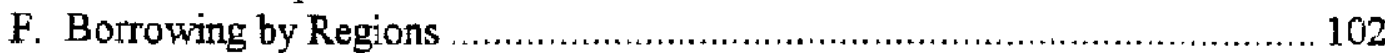

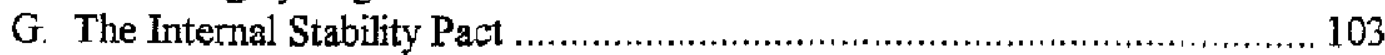

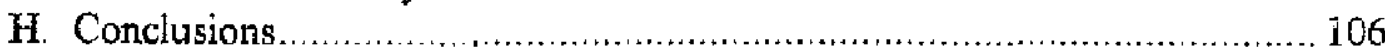

Tables

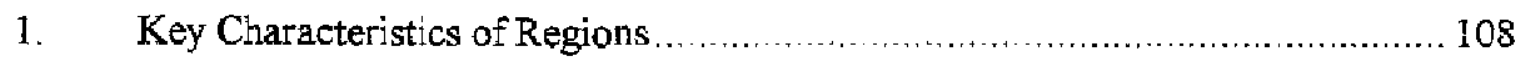

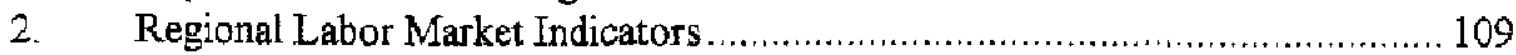

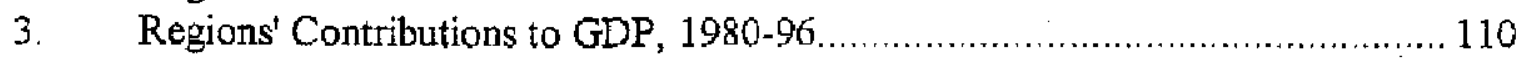

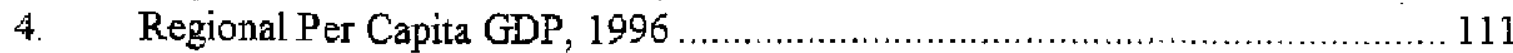

5. Consolidated Fiscal Accounts of Subnational Governments, $1976-98 \ldots \ldots \ldots \ldots \ldots 112$

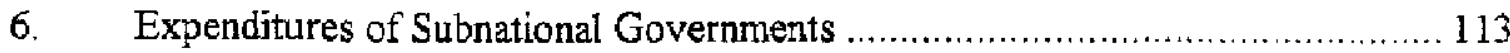

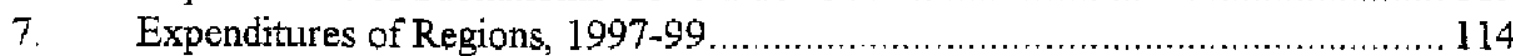

8. The Structure and Growth of Regional Current Health Care Expenditure ........ 115

9. Growth of Real Health Care Expenditure, $1980-97 \ldots \ldots \ldots \ldots \ldots \ldots \ldots \ldots \ldots \ldots \ldots 116$ 


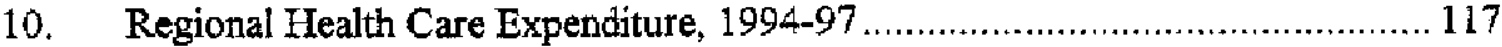

11. Structure of Regional Health Care Expenditure in $1996 \ldots \ldots \ldots \ldots \ldots \ldots \ldots \ldots \ldots \ldots \ldots \ldots 118$

12. Sources of Health Care Finance, 1993-97 ........................................119

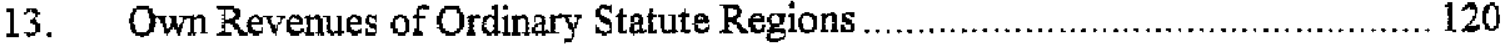

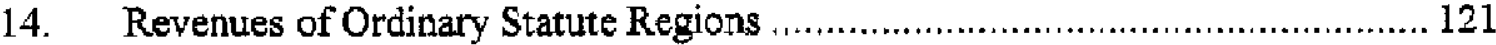

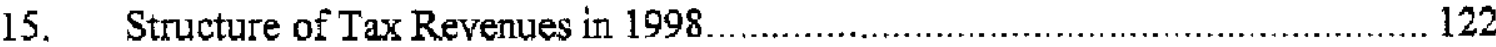

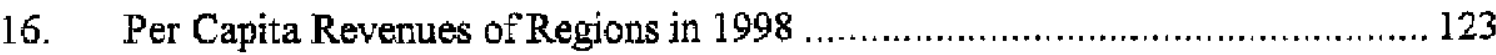

\section{$\underline{\text { Figures }}$}

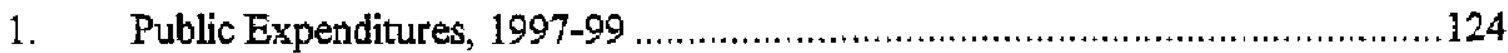

2. Composition of General Government Deficit, 1977-99 ............................125

3. The Share of Health Care Expenditure in GDP, 1960-97 ........................126

4. The Share of Total Health Care Expenditure in GDP, 1970-97 .....................127

5. Average Annual Growth Rates of Real Current Health Care Expenditure,

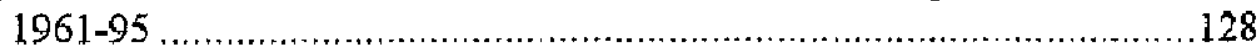

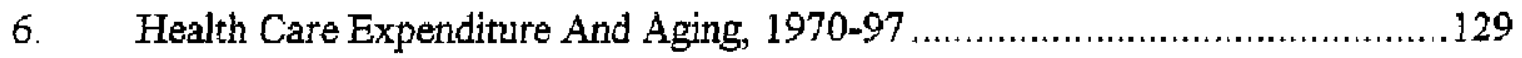

7. Health Care Expenditure and Aging in the Rest of the European Union,

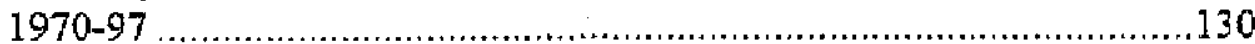

8. Inequality Among Regions in Income and Health Care Expenditure, 1997 _......131

9. Interregional Inequality in Regional Tax Bases and Total Regional Budget

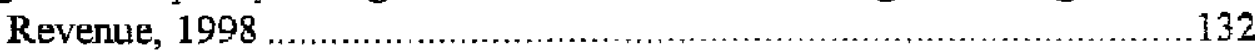

10. Projected Revenues of Regions in the First Year of the Transition ...................133

11. Interregional Inequality in Income and Budget Revenue, $1998 \ldots \ldots \ldots \ldots \ldots \ldots \ldots \ldots . \ldots 134$

12. Capacity to Raise Additional Revenue from Regional Taxes by Increasing Tax Rate ................................................................................135

13. Projected Total Revenues of Regions in the First Year of Transition ...............136

$\underline{\text { Text Boxes }}$

1. Tax Assignments and Tax Autonomy at the Intermediate Level of Subnational Governments in Selected EU Countries .............................................97

2. Internal Stability Pacts in Selected EU Countries ...................................... 104

Appendix:

The Main Regional Taxes ...................................................................... 137

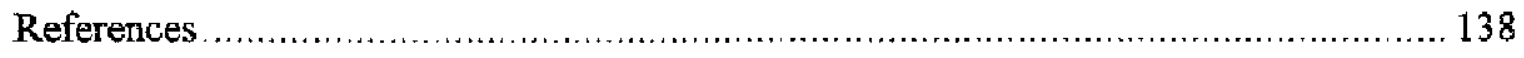

IV. Sources of Data and General Information on the World Wide Web .................., 140 
Italy: Basic Data

$\begin{array}{llc}\text { Area: } & \text { (Thousands sq. km) } & 301.336 \\ \text { Population: } & \text { (millions, 1998) } & 57.6 \\ \text { GDP per capita: } & 1999 & 20,356\end{array}$

(Percentage changes, exeept as otherwiso indicated)

\begin{tabular}{|c|c|c|c|c|c|c|}
\hline & 1995 & 1996 & 1997 & 1998 & 1999 & $20001 /$ \\
\hline \multicolumn{7}{|l|}{ Domestic economy } \\
\hline GDP & 2.9 & 1.1 & 1.8 & 1.5 & 1.4 & 2.7 \\
\hline Dontestic demand & 2.0 & 0.9 & 2.5 & 2.9 & 2.5 & 2.5 \\
\hline Consumption (households) & 1.7 & 1.2 & 3.0 & 2.3 & 1.7 & 1.8 \\
\hline Public consumption & -2.1 & 1.1 & 0.9 & 0.7 & 0.8 & 0.2 \\
\hline Gross fixed investruen: & 5.0 & 3.6 & 1.2 & 4.1 & 4.4 & 6.4 \\
\hline Moohinery and equipment & 10.6 & 3.7 & 4.2 & 7.4 & 6.2 & 7.5 \\
\hline Construction & 0.9 & 3.6 & -2.3 & -0.1 & 1.8 & 4.7 \\
\hline Inventories (eontritution) & 0.2 & +0.7 & 0.3 & 0.6 & 0.4 & 0.1 \\
\hline Foreign sector (contribution) & 1.0 & 0.2 & -0.6 & -1.3 & -1.0 & 0.3 \\
\hline Exports & 12.6 & 0.6 & 6.5 & 3.3 & -0.4 & 8.0 \\
\hline Imports & 9.7 & -0.3 & 10.2 & 9.1 & 3.4 & 7.4 \\
\hline Employment & -0.6 & 0.5 & 0.4 & 1.1 & 1.3 & 1.1 \\
\hline Unemployment & 11.6 & 116 & 11.7 & 11.8 & 11.4 & 11.0 \\
\hline Manufacturing valus added & 4.7 & -1.3 & 2.3 & 1.9 & 12 & 3.5 \\
\hline Labor costs & 4.7 & 5.8 & 4.6 & -2.0 & 2.4 & 2.5 \\
\hline Unit labor costs in manufacturing & 1.1 & 6.1 & 2.2 & -1.8 & 0.9 & 0.4 \\
\hline Consumer prices (period average) & 5.2 & 3.9 & 1.7 & 1.8 & 2.7 & 2.2 \\
\hline GDP deflator & 5.0 & 5.3 & 2.4 & 2.7 & 1.5 & 1.9 \\
\hline Output gsp & -1.1 & -2.0 & -2.3 & .2 .7 & -3.1 & -2.5 \\
\hline \multicolumn{7}{|l|}{ External accounts 2 } \\
\hline Export volume & 13.2 & -2.2 & 5.6 & 3.9 & -1.2 & 8.0 \\
\hline Import volomo & 9.7 & -43 & 11.2 & 11,1 & 0.4 & 7.4 \\
\hline Export unit vahue & 9.3 & 4.3 & -0.3 & 0.3 & -0.4 & 3.0 \\
\hline Import unit value & 12.3 & 0.0 & 0.1 & -4.7 & 3.7 & 7.1 \\
\hline Trade belanoe (in percent of CDP) & 3.5 & 4.4 & 3.4 & 3.1 & 1.8 & 1.6 \\
\hline Current account (in percent of GDP) & 2.3 & 3.2 & 2.8 & 1.8 & 0.9 & 0.8 \\
\hline Nominal effective exchange rate 3 f & -9.8 & 9.3 & 0.7 & -0.4 & -1.8 & .3 .4 \\
\hline Real effective exchange rate 3 / & -7.5 & 11.9 & 2.8 & 0.5 & .2 .0 & -3.7 \\
\hline \multicolumn{7}{|l|}{ Pablic finances (in percent of GDP) } \\
\hline \multicolumn{7}{|l|}{ General goyernuent } \\
\hline Revenues & 45.6 & 45.8 & 48.2 & 46.6 & 46.9 & 46.6 \\
\hline Expenditures & $\$ 3.2$ & 52.9 & 50.9 & 49.4 & 48.8 & 48.1 \\
\hline Balance & -7.6 & -7.1 & -2.7 & -2.8 & .1 .9 & -1.5 \\
\hline Primary balance & 3.9 & 4.4 & 6.7 & 5.3 & 4.9 & 5.1 \\
\hline Strucutal primary beiance & 4.5 & 53 & 7.9 & 6.6 & 6.5 & 6.3 \\
\hline Debt & 123.2 & 122.2 & 119.8 & 116.3 & 114.9 & i10.7 \\
\hline \multicolumn{7}{|l|}{ State sector } \\
\hline Balarce & -7.1 & .6 .8 & -2.6 & .2 .8 & .1 .5 & .1 .0 \\
\hline \multicolumn{7}{|l|}{ Financial vartables } \\
\hline$M 34$ & $\ldots$ & $\ldots$ & $\ldots$ & 1.6 & 3.4 & 4.3 \\
\hline Total domestic credit $5 / 6$ / & 4.3 & 5.2 & 3.5 & 4.4 & 7.8 & 6.8 \\
\hline of which: To nonstate sector $5 / 6 /$ & 2.4 & 3.2 & 5.2 & 9.2 & 13.4 & 12.9 \\
\hline Six-month rate ot Treastry bills $3 / 7$ & 10,9 & 8.6 & 6.4 & 5.0 & 3.0 & 3.8 \\
\hline Prime lending rate $4 / 7 /$ & 11.0 & 21.0 & 9.2 & 7.7 & 5.9 & 6.3 \\
\hline
\end{tabular}

Sorrces: Data provided by the Italian arthorities; and Fund staff estimates and projections.

1/ Staff estimates and projections, unless otherwise indicated.

$2 /$ Volumes and unit values are customs basis; trade balance and current account are belance of payments besis.

3/ Data for 2000 refer to first quarter.

4/ Date for 2000 refer to January.

5/ End-of-period; data break in 1998.

6 Data for 2000 refer to February.

$7 /$ Period average. 


\section{INTRODUCTION AND OVERVIEW}

1. Following Italy's successful drive to achieve founder membership in European Economic and Monetary Union (EMU), the focus of the economic policy debate is shifting toward structural, longer-term issues. Against the background of a decade of weak economic growth, the key challenge is to identify and implement policies that would strengthen growth and spread its fruits more widely in terms of employment creation and regional economic performance.

2. The three chapters of this paper shed light on several, closely related, aspects of this challenge--and in particular on the contribution that fiscal policy can make, together with flanking structural reforms. The analytical work reported in Chapter I attempts to identify the sources of Italy's weak growth performance from a cross-country perspective--and attributes it, at least in part, to a high and rising tax burden. While lowering the tax burden would therefore seem desirable, fiscal policy is severely constrained not only by the Stability and Growth Pact, but also by the still high level of public debt and the future fiscal burden related to population aging. These longet-run fiscal trade-offs, and their implications for growth, are discussed in Chapter II. One fiscal sector that is likely to be affected strongly by population aging is health care, and past reforns and future challenges are discussed in Chapter III; issues related to pensions were analyzed in last year's background papers (see Chapter $I$ in SM/99/115, 5/20/99). The rest of this section provides a brief overview of the three chapters.

3. Chapter I-Puxaling Out Italy's Growth Performance-investigates the factors behind Italy's relatively weak growth during the past decade. Employing a cross-country approach, Italy's experience is set against that of France, the Netheriands, and the United Kingdom. On the demand side, the empirical results confirm past work, suggesting that restrictive fiscal and monetary policies--indispensable for participation in EMU--weakened growth to some extent. However, these demand-side factors account for only a small part of Italy's growth differential vis-à-vis the comparator countries-notably, the Netherlands and the United Kingdom-suggesting that structural factors may have played a central role. A simple growth accounting exercise suggests that Jow employment growth (as opposed to weak capital or total factor productivity growth) was the main culprit behind Italy's poor growth performance; accordingly, the chapter focuses on structural factors in the labor market, including the role of labor taxation.

4. The labor market analysis decomposes the observed labor market movements into structural labor demand and supply factors. On the labor demand side, there is evidence in most countries of a fall in demand over the past two decades, reflecting exogenous technological shifts and, in Italy especially in the 1990s, perhaps also a reduction of "featherbedding" as union power declined and a major privatization program took hold. More importantly, there is evidence that labor supply in Italy expanded much less than in the comparator countries, as wages (adjusted for productivity) responded to a much smaller degree to unemployment than in the comparator countries. Moreover, the results point to regional asymmetries in Italy, with rising unemployment in the South having no discernible 
impact on productivity-adjusted wages. In assessing the relatively smatl response of pretax wages to adverse labor market developments, the analysis suggests that the sharp increase in the fiscal burden in Italy during the past decade may have been an important factor: the squeeze on (after-tax) wages due to rising taxes made pre-tax wage moderation more difficult than, for example, in the Netherlands, where the labor tax burden fell substantially over this period, raising household income.

5. The need for a durable reduction of the fiscal burden is one of the considerations underiying the discussion of an appropriate medium- and long-term fiscal strategy-the topic of Chapter II: Italy's Fiscal Strategy in a Medium-Term Framework. The analysis is anchored on long-term considerations that take explicitly into account the impact on the public finances of population aging - projected to be more adverse than in most industrial countries. Population aging affects the public finances in mainly two ways: first, it raises public expenditure, notabiy on pensions and health care (only partially offset by a decline in spending on education); and, second, it lowers the rate of potential output growth, as the labor force declines.

6. Against this background, two alternative fiscal scenarios are discussed: a baseline scenario, which broadly follows the Italian authorities' Stability Program through 2003 and maintains a balanced budget over the longer-fun, with some reductions in the fiscal burden and the ratio of expenditure to GDP; and a more ambitious reform scenario, aiming at faster debt reduction (with the primary surplus maintained at somewhat over 6 percent of GDP over the cycle, resulting in substantial surphuses in the overall balance by the end of the current decade), along with deeper revenue and expenditure cuts. A comparison between the two scenarios illustrates some of the advantages of aiming at relatively fast, early debt reduction. While under the baseline scenario the debt ratio keeps falling monotonically, its pace of decline is not fast enough to bring it below the Stability and Growth Pact ceiling of 60 percent of GDP by the time the most adverse phase of the demographic shock takes place; this leaves very little room to accommodate the shock, and the fiscal burden has to rise precisely at the time when the decline in the labor force is steepest. By contrast, the more ambitious reform scenario attains a debt ratio below the 60 percert reference value much earlier (around 2010). This leaves sufficient room for the deficit and debt ratios to temporarily rise again during the most adverse phase of the demographic shock so as to keep the fiscal burden unchanged. These long-run simulations are subject to considerable uncertainty about the underlying structural parameters, and the chapter also discusses some alternative specifications (for example, with respect to labor productivity growth).

7. The results in Chapters I and II underscore the pivotal role of public expenditure restraint, needed not only for public debt recuction but also for lowering the tax burden and strengthening growth - a politically difficult task as demonstrated by the Italian experience and that of other courttries. Chapter III-The Evolving Role of Regions in Italy: The Financing and Management of Health Care Services-focuses on one key expenditure area, health care spending. Health care spending is of particular importance for at least two reasons: it is, aside from pensions, the expenditure category that will be most adversely 
affected by the upcoming demographic shock; and it constitutes the bulk of regional government expenditure, where sizable overruns have emerged in the past. Moreover, the issue is particularly topical, as the Italian authorities are currently in the midst of reforming the health care system, including through increased fiscal devolution to the regions.

8. The recent and pending reforms of the health care system are raising the regions' own resources, including through expanded discretion in setting rates on local taxes; and it replaces the old system of central government transfers by an equalization mechanisms that specifies interregional transfers on the basis of regional tax bases (depending on levels of activity) and health care needs (depending on demographic characteristics). The new system-which is also reviewed from a cross-country perspective-improves fiscal transparency by setting clear rules for intergovernmental fiscal relationships. Nonetheless, potential problems could arise if: systematic differences in administrative capacity among regions are not addressed; growth differences persist between regions of a scale experienced in the past; and slow-growth regions are forced to raise their regional tax rates (which could aggravate regional disparities, should the tax base prove sufficiently mobile). Moreover, present reforms do not address the pending pressure on health care expenditure due to population aging-central if the challenges are to be addressed that were identified in Chapters $I$ and $I$, and a point that is well recognized by the authorities. 


\section{Puzzling Out Italy's Growth Performance ${ }^{1}$}

9. Economic growth in Italy has been subdued during the 1990 s, which, in turn, has prompted a search for explanations. With the objective of ultimately reaching policy conclusions, this chapter evaluates the merits of various hypotheses that have been advanced to explain Italy's performance. Since both the decline in growth by comparison with the $1980 \mathrm{~s}$ and Italy's underperformance relative to European Union (EU) partner countries as well as most other industrial countries have attracted attention, the paper takes a cross-country approach in assessing the various hypotheses. The comparator countries chosen are France, the Netherlands, and the United Kingdom. Focusing on several countries rather than on EU averages, for example, makes it easier to pinpoint structurat or demand-side explanatory factors for differing growth rates; these factors are easily concealed by averages. Moreover, the three countries are fairly heterogeneous in their macroeconomic and structural policies as well as growth outcomes, thereby fostering more interesting comparisons with Italy: France, together with Italy, recorded below EU-average growth, while the United Kingdom and the Netherlands benefited, respectively, from average and above-average growth.

10. Relative to the comparator countries, Italy's average annual teal GDP growth during 1990-98 lagged to varying degrees (Table 1). Lower working-age population growth (Table 2) may have played a role, but a per (working age) capita growth differential of 1 percentage point remains relative to the Netherlands, and of $1 / 3-3 / 4$ percentage point relative the United Kingdom depending on whether the focus is on total or business GDP, respectively. However, demographic factors are unlikely to have been a major constraint on growth, as labor force participation did not rise, nor did unemployment decline.

11. This chapter argues that structural impediments-and not mainly macroeconomic policies-have precluded Italy from growing at a pace similar to that of the Netherlands or the United Kingdom over the past decade. The starting point for investigating structural growth impediments is a standard growth accounting exercise. The results from the exercise suggest that Italy has been lagging the Netherlands and the United Kingdom mainly with respect to employment creation. Studying the labor market reveals that Italy suffered more adverse structural labor demand developments, which may have been related to insufficient wage dispersion and, during the $1990 \mathrm{~s}$, to enterprise restructuring. However, the main difference relative to the comparators lies in labor supply developments: considering relative labor market conditions, there was less moderation of gross wages in Italy than elsewhere. This is likely to have been related to developments in labor taxes. While moderation of pre-tax wages was supported through tax and contribution reductions in the Netherlands over the past two decades, labor taxes increased sharply in Italy.

${ }^{1}$ Prepared by Jörg Decressin. 
12. The paper is structured as follows: Section A scrutinizes demand-side explanations for Italy's underperformance. Section B elaborates on various structural bypotheses to explain Italy's lower growth; and Section $\mathrm{C}$ concludes and draws policy lessons.

\section{A. Demand-Side Developments}

13. Demand-side policies, notably a tighter fiscal stance and higher interest rates than in the comparator countries, have been held accountable for Italy's lower growth over the past decade. This section shows that under similar macroeconomic policies, Italy's GDP growth would have been comparable to that of France over the 1990s. However, relative to the Netherlands and the United Kingdom, annual growth differentials of $1-1 \frac{1}{2}$ percentage points remain. Considering that absent a policy tightening, Italy's euro participation would not have been feasible and macroeconomic policies not sustainable-with implications for risk premia and growth that are not well captured in the simulation exercise-the simulation results probably present an upper bound on the impact of policy tightening. Thus, structural rather than demand-side factors probably explain Italy's lower GDP growth relative to these two countries.

14. A recent European Commission (EC) study (European Commission (2000)) focuses on a demand-side analysis of economic developments. It argues that a tighter fiscal policy only partly explains Italy's lower growth. Had the primary fiscal balance been left unchanged starting in 1996-implying a 21/2 percent and 1 percent of GDP lower surplus in 1997 and 1998, respectively - the EC study estimates that annual real GDP growth in 1997-98 would have been about $1 / 2$ percentage point higher, leaving it still much lower than in the comparators.

15. This section explains how Italy's real GDP growth might have differed, had it been able to adopt the same fiscal policies as the comparators bad over 1992-98 and benefited from the same interest and exchange rate developments. While this exercise may not assess Italy's growth under a viable counterfactual scenario, it is nonetheless essential to understand Italy's growth performance during the $1990 \mathrm{~s}$.

16. Italy experienced the largest withdrawal of fiscal stimulus over 1992-98, as measured by the change in the primary structural fiscal balance (Figure 1): over this period Italy had the lowest and highest growth in structurai primary expenditure and structural revenue, respectively. Both the size and the length of the adjustment effort likely have affected growth. Concerning monetary policy, the differences across countries are subtler. While Italy clearly had the highest real interest rates during the $1990 \mathrm{~s}$, it also benefited from the largest decline in long- and short-term interest rates, albeit mostly in the course of 1996-98. Both interest rate levels and changes matter for investment; however, to the extent that the stock of capital had 
adjusted to a level consistent with interest rates prevailing in 1990-91, interest rate changes may be more relevant. ${ }^{2}$

17. The question that then arises is how real GDP growth in Italy would have fared, if the country had adopted the same fiscal policy that the comparators did and benefited from the same interest rate and exchange rate changes during the 1990s. A "same fiscal policy" is defined as a policy that would have imparted the same fiscal impulse- as measured by the estimated change in the structural primary fiscal balance-as in the comparator countries. ${ }^{3}$ The differences between the Italian impulse on the one hand and that in the comparator countries on the other are assumed to be reflected entirely in higher or lower public consumption, depending on whether the fiscal impulse in Italy was smaller or larger, respectively.

18. From Table 3 it is possible to see how the fiscal impulse (and thus public consumption) and changes in interest rates and in the exchange rate would have differed for Italy, had they evolved as in the comparator countries. The table also displays the elasticities of the real GDP level with respect to these variables of the pre-EMU Oxford Economic Forecasting (OEF) Model. ${ }^{4}$ These elasticities are used to compute -in Tables 3-4-how GDP growth in Italy

\footnotetext{
${ }^{2}$ This is not an inconceivable hypothesis, as long-term interest rates remained broadly constant or decreased slightly in real terms during 1986-90 in all countries except the United Kingdom, where there was a more marked decline.
}

${ }^{3}$ The fiscal impulse is measured as the change in the structural primary balance of the general government, rather than the overall structural balance recommended by Schinasi and Lutz (1991), as changes in the interest bill are covered under the calculations that assess how the Italian economy would have evolved, if it had it benefited from the same interest rate changes than the comparator countries.

${ }^{4}$ See OEF (1996). The OEF model is a mainstream economic model, situated in the middle ground between purely statistical models of the economy on the one hand (e.g, vector autoregressions (VAR)) and computable general equilibrium models (CGEMs) on the other Like CGEMs, the model imposes certain parameter restrictions based on theoretical priors. However, like VARs, it also estimates other parameter coefficients with country data to ensure that the model does well in reproducing short-run behavior as well as cointegrating relationships between key variables observed in VARs. The model exhibits "Keynesian" features in the short run and "neoclassical" ones in the long run. Its key characteristics are as follows: (i) countries have a natural long-run growth rate but aggregate demand need not match supply in the short run; (ii) monetary policy, which is characterized by a Taylor rule, cannot affect output in the long run; (iii) consumption is a function of real incomes, real financial wealth, the real interest rate, and inflation; (iv) investment equations are influenced by q-theories, in which investment is a function of its opportunity cost after taking taxes into account, as well as accelerator effects; and (v) the country is small with terms of trade 
would have differed under the comparators' fiscal policies, and interest and exchange rate changes, during 1992-98. Under the policies and conditions of France and the Netherlands, Italy's real GDP would have grown faster by about $1 \%$ percentage point than it actually did; under the United Kingdom's economic scenario; it would actually have grown some $1 / 3$ percentage point slower. Fiscal policy mainly explains the growth differentials; only relative to the United Kingdom was the estimated impact of alternative monetary and exchange rate paths larger than for alternative fiscal policies.

19. The results can also be used to evaluate the growth performance over 1996-98. The model suggests that under similar fiscal policies and monetary conditions, average annual growth in Italy would have been higher by $3 / 4$ and 1 percentage point, respectively, relative to France and the Netherlands; by contrast, growth would have been considerably lower relative to the United Kingdom. Relative to France and the Netherlands, the growth differentials during this period largely reflect the lira's appreciation since 1996.

20. In evaluating the simulation results, it is important to bear in mind the limitations of this exercise. First, the OEF model, which was used in the exercise, may overestimate the short- run effects of changes in policies and monetary conditions on output. Second, if Italy had been able to meet the Maastricht fiscal deficit criterion with discretionary policy changes of the magnitude of such changes in France or the Netherlands, it might have chosen to forego much of the increase in fiscal revenues, which is where most of the fiscal adjustment during the 1990s was achieved, rather than allocate additional expenditure to pubiic consumption. Third, and perhaps most important, pursuing policies comparable to those adopted by France, the Netherlands, and the United Kingdom was not an option for Italy without foregoing the benefits of euro entry: interest rate premia would then likely have been higher, with adverse effects on growth. Bearing these caveats in mind, even the simulations results suggest that structural impediments-and not mainly macroeconomic policies-precluded Italy from growing at a pace similar to that of the Netherlands or the United Kingciom over the past decade: most of Italy's growth differential during 1992-98 relative to these countries cannot be accounted for by macroeconomic policies and developments under the OEF model.

determined and exports a function of world demand and external demand. The model is backward-looking. with equations featuring an error correction component. In the simulations, monetary policy is left to act in line with the Taylor rule assumed under the model

${ }^{5}$ Altimari and others (1997) run policy simulations on the Bank of Itgly model and find that an increase in interest rates of 1 percentage point over a limited period of two years reaches its peak effect on the real economy in the second year, with output being about 0.5 percentage points below baseline. Under the pre-EMU OEF model, the effect would have been a decline of 0.7 percent below baseline. 


\section{B. Structural Impediments}

21. Various structural features of the Italian economy have been considered responsible for the country's underperformance. At the risk of oversimplifying, they can be grouped as follows: (i) low productivity growth, owing to distorted product markets (Table 5), as well as a lack of education (Table 6) and innovation (Table 7); (ii) high labor (Table 8) and capital income (Table 9) taxes, which hold back employment and capital accumulation; (iii) distortive labor market regulation (Table 10); and (iv) rigidities in the Mezzogiomo, the poorer south of Italy, which hold back growth at the national level (Tabie 11).

22. Growth accounting may help discriminate between various explanatory factors.

Decomposing business sector real GDP growth reveals that Italy has lagged largely with respect to employment creation (Table 12). Problems in product markets, education, and research and the production structure would probably have been reflected in total factor productivity (TFP). TFP growth was somewhat smaller than in the comparator countries, except for the Netherlands; but the slowdown in productivity growth during the $1990 \mathrm{~s}$ is difficult to rationalize. The product and services market environment clearly improved during this period, possibly even more rapidly in Italy than in most of the comparator countries. However, before the reforms began, Italy was lagging considerably behind the United Kingdom and the Netherlands. Similarly, no compelling case can be made that Italy has been falling behind with respect to education and research and development: on the contrary, the evidence suggests that Italy is catching up.

23. Tuming to capital accumulation, the results show neither major differences between Italy and the comparators, nor a change in the contribution of capital over time. Several comments are in order: First, much of the slowdown in investment in Italy was in the public sector, and in construction, particularly for residential purposes, as indicated by a comparison of private nonresidential fixed investment with total gross fixed capital formation (Table 13). Second, while Italy stands out in having recorded a large increase in capital income taxes during 1980-96, the burden on capital was not necessarily higher than in the comparator countries over most of the period, and tax rates have recently come down considerably. Third, the results of the growth accounting exercise may be tainted by measurement error. Using other measures for factor inputs reveals that the contribution of capital to growth was declining in Italy during the 1990s (Box 1), although not nearly to an extent that would invalidate the fundamental result of the accounting exercise: Italy's low output growth is closely related to developments in employment, a hypothesis that finds support in the evolution of the capital-output ratios (Figure 2).

24. Overall, growth accounting suggests that Italy's subdued economic performance may be rooted in the labor market. This hypothesis appears as valid for the center-north of Italy as for the poorer South (Table 11) and is investigated furtber below. Note, though, that distorted product markets, less education and research, and lower capital accumulation may have directly affected the contribution of labor rather than TFP: growth accounting cannot offer firm conclusions on causal relationships. 


\section{Box 1. Selected Data Issues}

This box first proceeds to a growth accounting exercise for the business sector in Italy, however, unlike in the text, it excludes agriculture and energy. Second, it investigates the issue of the measurement of employment in terms of the number of employed (henceforth referred to as "bodies") versus effective units.

Tabie A displays the results from growth accounting, obtained using the same shares of labor in business sector income as in the main text. The data for this growth accounting exercise differ in two important respects from the OECD data used in the text: (i) they do not include agriculture and energy; and (ii) the employment data are in effective urits, basically the equivalent of man years. The results from the growth accounting exercise in the text are displayed as well. Compared with the exercise reported in the main text, the differences are most pronounced for the roles of employment and capital. The data for the entire business sector suggest a larger and straller contribution of capital and labor, respectively. Also, for the 1990s they suggest a small increase rather than a decline in the contribution of capital to growth.

Table B investigates the differences between the evolution of employment in effective units versus "bodies." These data series can differ, for example, because of changing part-time employment or working time in general. In principle, it is preferable to use data in effective units rather than bodies in much of the work presented in this chapter. However, adjusting data in bodies to obtain effective units is hard because reliable data, particularly on actual working time, are difficult to obtain, even for the manufacturing sector. As can be seen, for Italy the average annual growth rate of business sector employment in units (ISTAT) is marginally lower than of employment in "bodies" (OECD). The opposite holds for the Netherlands, although the differences between data in units for the entire economy and data in bodies for the business sector are fairly small.

Data in effective units rather than "bodies" are preferable for computing labor costs. Labor costs are typically computed by dividing the wage bill through employment and, to the extent the evolution over time is interesting, dividing through some index of labot-augmenting technological progress (for example, total factor productivity scaled by the labor share). If employment is measured in bodies rather than effective units and bodies have grewn much more rapidly than units (say because of a sharp inctease in part-time employment, as experienced by the Netherlands), both the per capita labor cost and labor-augmenting technological progress could be underestimated. However, the effect of the former on productivity adjusted labor costs may dominate that of the latter.

Regardless of the data used in the growth accounting exercise, the key conclusion for Italy remains that the contribution of labor to growth was very low. Also, the data for employment in bodies and units for Italy and the Netheriands do not suggest that major biases result from using employment in bodies rather than units to compute productivity adjusted labor cost figures. Nevertheless, the role of working time is an issue that deserves further investigation (for a discussion of working time in manufacturing, see Casadio and D'Aurizio, 1999).

Table A. Italy: Growth Accounting, 1980-98 1/

\begin{tabular}{lcccc}
\hline & GDP & TFP & $\mathrm{L}$ & $\mathrm{K}$ \\
\hline $1990-98$ & 1.6 & 0.9 & 0.1 & 0.7 \\
$1990-9827$ & 1.5 & 0.7 & -0.2 & 1.0 \\
& & & & \\
$1980-89$ & 2.7 & 1.2 & 0.6 & 0.9 \\
$1980-8921$ & 2.5 & 1.2 & 0.4 & 0.9 \\
$1980-98$ & 2.2 & 1.0 & 0.4 & 0.8 \\
$1980-9821$ & 2.0 & 1.0 & 0.1 & 1.0 \\
\hline
\end{tabular}

Source: Bank of Italy, unless otherwise noted.

1) Data are for business sector, excluding agriculture and energy.

2/ Data are from OECD and cover the entire business sector.
Table B. Italy: Bodies and Units, 1981-95

\begin{tabular}{lr}
\hline & $1981-95$ \\
\hline \multicolumn{2}{c}{ (Arnual percentage change) } \\
Italy & \\
Bodies & -0.1 \\
Units & -0.2 \\
& \\
Netherlands & \\
Units 1/ & 0.6 \\
Bodies & 0.7 \\
\hline
\end{tabular}

Sources: For Italy, ISTAT; and SVMEZ; for Netherlatids, OECD; and Fund staff calculations.

1/ Refers to entire economy; all other data are for the business sector. 


\section{The labor market}

25. Italy's low growth appears closely linked to insufficient employment creation. Could the slow employment growth be related to labor market distortions and high labor costs? Answering this question requires an analysis of demand- and supply-side developments on the labor market.

26. Labor costs appear to have risen faster in Italy than in the comparator countries. Data for mamufacturing labor costs (Bureau of Labor Statistics, 1999 and 2000) suggest that Italy experienced the largest cost increases since 1980 (Figure 3a). Similarly, real product wages in the broader business sector (Figure 3b)-these data underlie all subsequent analysis-grew considerably faster in Italy than in France and the Netherlands, albeit not more rapidly than in the United Kingdom.

27. However, labor costs alone tell little about potential distortions. A country with high real wage growth can have a less distorted labor market than a country with low growth. This can be the case if wages are driven by rising labor demand related, for example, to favorable productivity. To reach a more definite assessment of the labor market, several measures for determining structural labor supply and demand will be reviewed, following Blanchard (1998).

\section{Labor supply}

28. Labor supply is assumed to be characterized by a wage-setting function that relates real wages to unemployment rates. ${ }^{6}$ Assuming labor-augmenting technological progress, ${ }^{7}$ real wages $w$ can grow at the rate of $a$, which is given by TFP scaled by the labor share in income $\alpha$. Define the real effective wage as $\omega$, with $\omega=\log (w / \alpha)$, then the wage reiation is given by $\omega$ $=-\beta U+Z$, where $U$ stands for the unemployment rate. Changes in $Z$ can be thought of as shifts

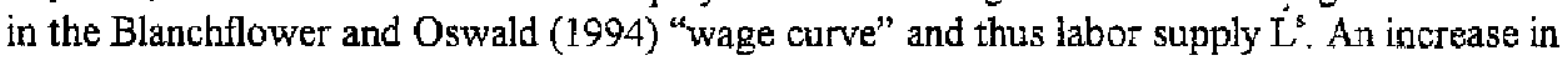
$Z$ implies that workers ask for a bigher real wage although unemployment has not declined and is equivalent to a drop in labor supply. The relation assumes reservation (and thus actual) wages rise with productivity: history clearly suggests no relation between productivity and employment levels or unemployment rates in the long run. However, if workers' aspirations lag reality, reservation wages are unlikely to adjust instantaneously with TFP, giving rise to labor supply shocks in this model.

29. Is it sensible to build on such a wage relation? One perspective is offered by the job matching approach and wage bargaining. ${ }^{8}$ Workers cannot costlessly relocate to find a new

\footnotetext{
${ }^{6}$ See Blanchflower and Oswald (1994) and Blanchard and Katz (1997).

"This assumption ensures the existerce of a well-specifjed, steady-state growth path, with an unchanged capital-output ratio. See, for example, Romer (1996).

${ }^{8}$ Pissarides (1990)
} 
job nor can they costlessly and instantaneously be replaced by their employers. In a depressed labor market, workers will settle for a wage close to the reservation wage because it is hard to find a job elsewhere. The opposite holds for a booming labor market. Alternatively, models focus on the firm-worker relationship, arguing that wages affect productivity. Firms may want to pay more to workers than their reservation wage to economize on turnover costs, motivate greater effort, or for social considerations, such as fairness. ${ }^{9}$

30. The following equation can thus be taken to characterize the evolution of labor supply $\mathrm{L}^{\mathrm{s}}$ over time:

$$
\Delta L_{t}^{s}=-\Delta Z_{t}=-\Delta\left[\omega_{t}+\beta U_{t}\right]
$$

With data for $U, w$, and $\alpha$ available, while $a$ can be obtained from the growth accounting exercise (see Data Appendix for details), assessing labor supply developments requires an estimate for the parameter $\beta$. Blanchflower and Oswald (1995) investigate the relation between real wages and unemployment for three out of the four countries considered here (Italy, the Netherlands, and the United Kingdom). Using broadly comparable microeconomic data, they estimate a cross-sectional eamings equation for each country, in which, together with the usual set of control variables, ${ }^{10}$ the regional unemployment rate is entered as an explanatory variable. They demonstrate that there appears to be an empirical regularity in international pay and unemployment data, whereby estimates of the unemployment elasticity of pay cluster around -0.1 . This result is broadly consistent with $\beta=1$, considering the average unemployment rates in the countries, impiying an increase in unemployment by 1 percentage point decreases effective wages by 1 percent. Note, however, that for Italy Brunello and others (1999), using a different model set-up and macroeconomic data, find evidence suggesting that $\beta$ is closer to 2 rather than $I$ in the long run. ${ }^{1}$

31. The data suggest that for given labor market conditions, labor costs declined in all countries. Figure 4 plots a five-year moving average of $Z$ to better capture structural changes: it can be thought of as the path of real effective wages at given unemployment rates in the various countries. The relation suggests that labor costs declined least in Itaty, where effective wage growth did not slow during the second half of the 1980s, considering developments in unemployment. Relative to the Netherlands; for example, costs in Italy were scaled back some

\footnotetext{
${ }^{9}$ See, for exampie, Shapiro and Stiglitz (1984); Katz (1986); and Akerlof and Yellen (1990).

${ }^{10}$ These variables include dummies for the industry and region in which a worker is employed; his or her gender, marital status, experience, schooling, rank, and union status.

${ }^{11}$ For the United States, evidence in Blanchard and Katz (1997) suggests a value for $\beta$, which is smaller than 1 in the short run but larger in the long run.
} 
15 percentage points less. Setting $\beta=2$ changes this result little, although it now appears that labor costs have declined considerably less in France than under $\beta=1$.

32. A question that arises is whether the unemployment rate is the right measure of labor market conditions. ${ }^{12}$ To the extent that the distinctions between being unemployed or out of the labor force are sometimes blurred-for example, owing to the discouraged worker effect or because of early retirement and disability support, measures that have been relied on in France, the Netherlands, or Italy to various degrees--the labor force participation rate (L/P) may better gauge labor market conditions. Nonetheless, substituting (1-L/P) for $U$ in calculating the evolution of labor supply does not change the results noticeably for Italy although it does so for France.

\section{Labor demand}

33. How can labor demand developments be measured? Assume the following CES-type production:

$$
y=A\left[\alpha(a n)^{\frac{\sigma-1}{\sigma}}+(1-\alpha) k^{\frac{\sigma-1}{\sigma}}\right]^{\frac{\sigma}{\sigma-1}}
$$

where $n$ stands for labor, $k$ for capital, and $\sigma$ for the (constant) elasticity of substitution between effective labor (an) and capital. To find labor demand, set the marginal product of labor equal to the real effective wage (w/a) multiplied by a markup $(1+\mu)$ :

$$
\frac{\partial y}{\partial n}=(1+\mu) w
$$

with the markup resulting, for example, from "efficient bargaining." 1.3 Take natural logarithms and rearrange to find:

$$
\log (1+\mu)=\text { constant }+\log \alpha-\log (w / a)-\frac{1}{\sigma} \log \left(\frac{a n}{y}\right)
$$

34. There are two perspectives to changes in labor demand. A technology-driven decline in labor demand can be thought of as a drop in $\alpha$ for unchanged $\mu$. Alternatively, a drop in demand because of less union bargaining power can be thought of as an increase in $\mu$ for given

\footnotetext{
${ }^{12}$ See, for example, Murphy and Topel (1997).
}

${ }^{13}$ See Rotemberg and Woodford (1999). With efficient bargaining the marginal product of labor is set equal to the reservation wage of the worker; however, the wage paid is a weighted average of the marginal and average product of labor: here this would imply $\mu<1$. See Casavola and others (1999) for some evidence suggestive of monopsony power in wage setting in Italy. 
a. Observationally these changes in labor demand $L^{d}$ are equivalent and their change over time is given by:

$$
\Delta L_{t}^{d}=\Delta\left[\log \left(w_{t} / a_{t}\right)+\frac{1}{\sigma} \log \left(\frac{a_{t} n_{t}}{y_{t}}\right)\right]
$$

Conveniently, for $\sigma=1$, the evolution of labor demand is given simply by the natural logarithm of the labor share in income (Figure 5).

35. Note that equations (4) and (5) assume no costs of adjusting factor proportions. If it is costly for firms to adjust factor proportions, an increase in the wage will be associated with little contemporaneous change in ( $a n / k)$ and thus ( $a n / y)$; this in tum will lead to a decrease in the measured wedge. To allow for adjustment costs in factor proportions Blanchard (1998) proposes to replace $\log (w / a)$ with $\log \left(w_{i}^{*}\right)=0.8 \log w_{t-1}^{*}+0.2 \log \left(w_{i} / a_{t}\right)$ in computing $\mathrm{L}^{\mathrm{d}}$, implying a mean lag in the adjustment of factor proportions of four years: ${ }^{\text {it }}$ the results are fairly similar.

36. The evidence suggests that labor demand has declined in all countries except the United Kingdom over the past two decades (Figure 5). Upon allowing for costs in adjusting factor proportions and an elasticity of substitution less than 1, it is also clear that France and Italy suffered an about 5-10 percentage point larger demand decline-which was concentrated in the $1990 \mathrm{~s}$ - than the Netherlands.

\section{The regional dimension}

37. Italy appears to have experienced the smallest increase in labor supply-meaning the smallest decline in labor costs for given labor market conditions - and, together with France, the largest decline in labor demand. A question that arises is whether developments in Italy were largely driven by the poor performance of the southern labor market. Evidence in Table 11 suggests that this might not have been the case: the weight of the South in the overall economy-equivalent to about one-fourth-is too small and cross-regional differences, while sizeable, insufficiently large to account for the central role in Italy's relatively weak growth performance.

38. To explore the regional dimension of labor market development further, Figure 6 shows the evolution of labor demand and supply in the Center-North relative to that in the country as a whole. This exercise draws on a different data set and required the construction of regional capital stock data (see Data Appendix). For the latter reason, the results must be treated as only indicative. They suggest that labor demand evolved similarly across the country, a result that holds also for costs in adjusting factor proportions and $\sigma=3 / 4$. For labor

\footnotetext{
${ }^{14}$ The starting value for $w^{*}$ is set equal to $w / a$ for 1975 .
} 
supply, though, it appears that the reduction in labor costs in the Center-North was some 3-5 percentage points larger than in the country as a whole, depending on the value for $\beta$. The evolution of wage costs (and hence labor supply) of the Center-North was thus more like that of France.

39. In all, for given unemployment rates, labor costs declined considerably more in the Center-North than in the country as a whole. Labor demand, however, evolved quite similarly across the country. The comparatively low decline in labor costs observed at the national level is thus, to an important extent, related to South-specific developments and this needs to be borne in mind in designing a wage policy to boost employment. Box 2 examines the labor market problem of the South in more depth.

\section{Interpreting labor supply and demand developments}

\section{Tcxation}

40. Why has there been less of a labor supply increase in Italy, as evidenced by a smaller labor cost decline for given labor market conditions? Was it related to developments intrinsic to labor markets, such as trade unions bidding up wages, or to external factors? The argument developed here is that Italy experienced a sharp increase in the tax burden on labor during the 1980 s and 1990 s, quite in contrast to the comparator countries. Several points emerge from Table 8: first, Italy had the highest marginal tax wedges on labor income in $1996,{ }^{15}$ second, Italy and, to a much lesser extent, France exhibited a sharp increase in effective tax rates on labor (income taxes and social security payments) over the past two decades, and particularly since 1990 in Italy. This increase in the tax burden made wage moderation much more painful than in the comparator countries.

41. Slow labor cost growth has played an important role in raising employment growth in the Netherlands. Watson and others (1999) underscore that employment growth in this country reflected to a substantial degree agreement among the social partners on the need for slower wage growth, notably following the Wassenaar agreement of November $1982 ;{ }^{15}$ and they emphasize that wage moderation was supported by reductions of taxes and contributions:

\footnotetext{
${ }^{15}$ This holds particularly for second earners in a family and may help explain the lower labor force participation rate among women.

${ }^{16}$ In addition, growth was supported by a large rise in female labor force participation, driven by cultural patterns and a catch-up with the EU average.
} 


\section{Box 2. The Mezzogiorno Problem}

The most challenging questions facing policymakers in Italy relate to the structural problems of the Scuth. With southern per capita GDP at some 55 percent of the level in the Center-North, standard (neoclassical) growth theory suggests that the South should record considerably higher GDP growth than the Center-North. There is a vast literature on the duality of the Italian economy that blames an array of factors for the underdevelopment of the South: (i) inflexible labor markets, notably trade unions that force a harmonization of labor costs across regions; (ii) rising competition from northern firms as a result of falling transportation costs and a richer southern market-the latter owing to rising public transfers; (iii) a public policy approach that generated a capital-intensive industrial structure, unsuited to support local entrepreneurship; (iv) poor governance; and (v) low human capital. ${ }^{\dagger}$ This study focuses on labor costs and employment.

Concerning regional labor markets, the key development has been the sharp decline in employment in the South from 1992 onward (Figure 7). What lies behind the South-specific evolution in employment? Generally, it is the scaling down of government (nonbusiness) employment, as well as the drop in construction activity after the discovery of widespread abuse of public funds (tangentopoli) that has been blamed. In this respect, the figures in Table 14 underscore two points. First, as in the Center-North, the reversal in employment growth in the South after 1992 is largely explatined by developments in business services. Second, the turnaround in construction and nonbusiness services in the South accounts for about as much of the South-specific employment growth reversal (i.e., the change in employment growth in the South less the change in the CenterNorth, both in percent of 1980 total regional employment) as the slowdown in business services. As a result, the difference between regional unemployment rates widened considerably.

The evolutions of labor demand (equation 5) and supply (equation 1) in the South relative to the Center-North are shown in Figure 8. They siggest that labor demand in the South decined by an additional 5 percent. More noticeably, labor supply increased much less than in the Center-North: considering utemployment in the South relative to the Center-North, wages should have declined by some 10 percentage points for $\beta=1$ and 15 percentage points for $\beta=2$. However, there was little adjustment in practice. This is substantiated further in Brunello and others (2000), who find evidence consistent with aggregate wage setting in Itaiy depending only on the rate of unemployment prevailing in the Center-North.

The absence of a correlation between actual and predicted relative real wages over time, which has been particularly acute since $1992{ }^{2}$ probably reflects excessive centralization of wage bargaining, an issue that has been identified as one of the fundamental problems for the South in the literature.

'On point (i), see for example, Lutz (1963), Bodo and Sestito (1991), Casavola, Gavosto, and Sestito (1995), and Gavosto and Rossi (1997); on (ii), see Graziani (1979) and Faini (1983); on (iii), see Del Monte and Giannola (1978); on (iv) see Triglia (1992) and Tullio and Quarelia (1998); and on (v) see Brunetta and Tronti (1994).

2More recently, the phaseout of social security rebates, to be completed in 2001 , on newly-hired employees in the South (mainly in manufacturing) has hampered more relative wage adjustment as measured here (compensation of employees includes employer"paid social security contributions). 
according to their evidence, the gross wage of an average production worker rose by about 5 percent in real terms in the decade $1984-93$ but the take-home wage by some 10 percent. ${ }^{17}$ Developments in Italy were different. As is apparent in Figure $3 \mathrm{~b}$, wage moderation did not set in until a decade later than in the Netherlands, namely following the 1992/93 agreement between the social partners - an agreement which was similar to the Wassenaar agreement in some important respects. Since then, real product wages in the business sector have hardly increased; actually, considering the continuing rise in taxation and social security contributions, rough calculations suggest that take-home consumption wages may well have declined in real terms for large segments of the labor force ${ }^{18}$ However, notwithstanding such a potential decline in take-home consumption wages, considering the state of the labor market, gross wages have not displayed a moderation on the scale observed in the Netheriands after 1982, not least owing to tax and contribution hikes. And the effect gross wage moderation on hiring may have been delayed by stringent labor market regulation (see below).

42. A question that arises is why employment growth was lower in Italy over those years during which effective labor taxation was less high than in most comparator countries. Rising labor taxation can pose more problems than high labor taxation. Assuming that capital is internationally mobile while labor is not, the incidence of labor taxes ultimately falls fully on labor. High labor-taxed countries thus need not have higher unemployment rates. However, following payroll and other tax hikes, unemployment may well rise until unions agree to lower wage floors or cease to seek offsetting wage increases.

43. To understand the relation between labor taxation, wages, and employment, recall that what matters foremost for labor supply is the relation between post-tax pay and the reservation wage. The analysis here has focused on pre-tax pay, including employer-paid social security contributions. ${ }^{19}$ Assume, for simplicity, that reservation wages are based on alternative earnings, which are also taxed, and that taxation is proportional. Standard nodels then suggest that taxation does not matter for employment: the real post-tax wage and the reservation wage drop in tandem. ${ }^{20}$ However, there are various reasons why post-tax wages

\footnotetext{
${ }^{17}$ In addition, growth was supported by a large rise in female labor force participation, driven by cultural patterns and a catch-up with the EU average; and there was a general improvement in supply-side incentives in the labor market and adjustments in minimum wages.

${ }^{19}$ Such a decline might have been even more pronounced in the South, considering the progress made in raising taxes and contributions in this area of the country. See Decressin (1999) for evidence on the evolution of taxes and contributions in the South.

${ }^{19}$ For a very brief and clear treatment of this topic see Lindbeck (1996); for a fuller treatment see Pissarides (1997).

${ }^{20}$ See Layard, Nickell, and Jackman (1991).
} 
may not decline one-for-one as labor taxation rises: (i) individuals' utility may depend on both the level of income and its change; ${ }^{21}$ (ii) wage floors, such as those in Italy at the sectoral level, can prevent an adjustment in market wages in response to payroll tax hikes; (iii) progressive taxation can nartow differentials between market and reservation wages; and (iv) the reservation wage may be a function of untaxed nonmarket activities, such as tending to children or the elderly, which are important in Italy. ${ }^{22}$ Under such circumstances, rising labor taxation may result in an increase in pre-tax real wages, and lower employment-a scenario that likely has played an important role in Italy's labor market developments over the past decades.

44. The extent to which labor taxes affect the relation between post-tax pay and reservation wages both in the short and long run is fundamentally an empirical issue. In this regard the evidence in the literature is ambiguous: Blanchard and Katz (1997), for example, note that the cross-sectional evidence in Europe does not reveal much correlation between tax rates and unemployment rates, nor between changes in tax rates and unemployment rates.

45. By contrast, Daveri and Tabelini (1997) argue that if wages are set by strong trade unions, an increase in labor taxes is shifted onto higher real wages and resuits in higher unemployment: the continental European countries, unlike the other OECD countries, provide evidence for such a relation within countries over time. The authors' results suggest that a 10 percentage point increase in effective labor tax rates, through the effect on wages, can account for a 4 percentage point increase in European unemployment. Marino and Rinaldi (2000) find that for OECD countries, an increase in the effective labor tax rate by 1 percentage point (say, from 50 percent to 51 percent) is fully reflected in higher labor costs in the first year ${ }^{23}$ And, for Italy in particular, Brunello and others (2000) observe a cointegrating relationship between unemployment, the tax wedge, the real interest rate, and union power: ${ }^{24}$ according to their simulations, a reduction in the tax wedge from the level recordec in 1996 to that which prevailed in the early 1980 s would yield a 15 percent reduction in the unemployment rate, with about 70 percent of this reduction taking place within five

\footnotetext{
${ }^{21}$ There is supportive evidence for such behavior from work in the area of adaptation theory (for example, Argyle, 1987).

${ }^{22}$ OECD (2000).

${ }^{23}$ For the Netherlands, Watson and others (1999) find that an increase in taxes and social security contributions of 1 guilder raises labor costs by 0.7 guilder.

${ }^{24}$ Interestingly, in their theoretical model the positive relationship between taxes and unemployment does not emerge from real wage resistance to changes in the tax wedge but depends on the interaction between private wages, public wages, and public employment, which are linked together in the long rin by the government budget constraint.
} 
years. In all, although there is no compelling evidence for a cross-sectional relation between taxation Jevels and unemployment, there is a growing body of research substantiating a timeseries relation, that is, whereby an increase in labor taxes may be associated with higher unemployment, particularly for continental Europe.

\section{Union power and skill-biased technological progress}

46. What lies behind the declines in labor demand? Two potential explanations are worth highlighting: (i) a reduction in featherbedding related to a decline in union power, including in the context of privatization and restructuring of public enterprises in the business sector; and (ii) the substitution of capital for labor following skill-biased technological progress.

47. While it is difficult to believe that measures to reduce featherbedding can lower labor demand for 20 years, at least for Italy, they may have played a role. First, the demand decline accelerated in the $1990 \mathrm{~s}$ and thus could be related partly to privatization and public enterprise restructuring. In 1987, nine out of the ten largest firms (by tumover) were in public hands, with their receipts totaling more than the equivalent of 15 percent of GDP. This statistic changed little until 1994, when one of the largest privatization program among OECD countries left only two of these companies state controlled; following privatization, employment losses were sizable. In addition, fiscal consolidation called for restructuring poorly performing national monopolies: since 1990, employment losses in the railway and postal companies alone have amounted to some 160,000 , or the equivalent of some $2 / 3$ of 1 percent of the labor force. Second, if featherbedding had played an important role, employment losses would generally have been concentrated in larger firms and these losses would have risen as union power declined: both are documented for Italy in Brunello and others (1999). The drop in union power, which started in the $1980 \mathrm{~s}$, is documented in further detail in Bertola and Ichino (1995). And third, there is some evidence that actual per capita working hours have increased, while contractual hours have declined slightly: Casadio and D'Aurizio (1999) document that per capita working hours in manufacturing firms with more than 50 employees rose 12 percent during 1985-98, despite a small reduction in contractual hours. They observed that more cooperative industrial relations, as evidenced by structura: reductions in labor disputes and absenteeism, played an important role: both are equivalent to less featherhedding. ${ }^{23}$

48. Skill-biased technological progress can be thought of as a mean-preserving increase in the spread of the productivity distribution for workers actoss skill categories. If wage differentials do not widen in response (e.g., because unemployment benefits put a foor on

\footnotetext{
${ }^{25}$ Furthermore, they observe that small firms have used their resources more intensively over the entire period considered and that in the last five years, per capita working hours in the South have caught up with center-northern levels, which previously had been some 5 percent higher.
} 
reservation wages or due to egalitarian wage setting), such progress raises unemployment and thay prompt substitution of capital for lowmskilled labor. ${ }^{26}$

49. Within professions, wage differentials are currently lowest in Italy (Table 15), although across professions the evidence is less clear. Investigating the issue of wage differentiation more formally for the 1980 s, Freeman and Katz (1995) find that the United Kingdom experienced widening differentials similar to those of the United States; however, France, Italy, and the Netherlands did not. Erickson and Ichino (1995) show that Italy experienced a strong compression of wage differentials during the $1970 \mathrm{~s}$, similar to the better-known situation in Sweden. While this compression came to a stop around $1982-83$, there was no obvious reopening of differentials through 1990: by contrast, their results suggest that in the United States not only was the compensation structure less compressed, it also widened considerably. Brandolini and Sestito (1999) revisit and update the work of Erickson and Ichino: they find similar evidence for Italy for the 1980 s but observe a considerable widening of wage differentials during 1990-95; for male workers the widening even goes somewhat beyond levels recorded in the late $1970 \mathrm{~s}$. Their evidence is, therefore, not supportive of a labor-demand decline during the 1990 s driven by insufficient wage differentiation, unless it is interpreted as a continued response to developments in earlier decades, where it may have played an important role.

\section{Unemployment benefits and labor market regulations}

50. What about the role of unemployment benefits and labor market regulation? Benefits affect the suppiy of labor by setting a floor on reservation wages. Their variation across countries offers little in explaining differential labor supply (Table 10b). ${ }^{27}$

51. Hiring and firing restrictions reduce both employment inflows and outflows, leaving an ambiguous effect on the unemployment rate. ${ }^{2 B}$ However, by virtue of making employers more reluctant to fire as well as hire such legislation could explain the delayed response of employment to wage moderation in France and Italy: from the point of view of regulation, both countries compare unfavorably against the other countries in the sample (Table 10a) ${ }^{29}$

${ }^{26}$ See Mortensen and Pissarides (1999).

${ }^{27}$ Disability and early retirement have also been used to support job losers but a comparison of the systems and their use for this purpose lies beyond the scope of this chapter.

${ }^{28}$ See OECD (1999c) for evidence.

${ }^{29}$ Blanchard and Wolfers (2000) find that a model that aliows for both differing employment protection legislation and differing labor market shocks explains well the relative employment performance of European countries across time. These labor market shocks are defined as above in equation (5). 
This argument is developed further in Bertola and Ichino (1995): they argue that the wage moderation during 1993-95 in Italy may not have been sufficient to overcome employers' reluctance to hire, considering the difficulties involved in firing permanent employees. It is noteworthy that only following the reforms of fixed-term employment and temporary work agencies in the second half of the 1990s that employment grew rapidly, considering the low real GDP growth rates.

52. Turning to part-time employment, regulations were stricter in Italy and France. This could have adversely affected labor supply, particularly of women, which has boomed in the Netherlands. ${ }^{30}$ Importantly, flexible employment can raise firms' demand for labor by enabling them to fine-tune working time and output and thereby meet orders "just in time." A more liberal handling of such contracts, combined with wage moderation, appears to have an important effect on labor market developments in Italy.

\section{Concluding Remarks and Policy Implications}

53. Italy's growth performance has lagged, to varying degrees, that of France, the Netherlands, and the United Kingdom over the 1990s. This chapter has examined macroeconomic and structural factors potentially explaining the country's underperformance.

54. Macroeconomic policies were tighter in Italy than in the comparator countries over the $1990 \mathrm{~s}$. Accordingly, a question that arises is how Italy's real GDP growth would have differed, had it been able to adopt the same fiscal policies as the comparators over 1992-98 and benefited from the same interest and exchange rate developments. To answer this question, the chapter relied on the elasticities in the pre-EMU OEF Model of real GDP with respect to the relevant fiscal and monetary variables. The results suggest that more restrictive demand management could explain Italy's growth differential relative to France. However, relative to the Netherlands' annual growth differentials of some 1 percentage point remain, or about $2 / 3$ of 1 percentage point in per capita terms; even for the better-performing center-north of Italy the per capita differential would have amounted to some $1 / 2$ of 1 percentage point. Relative to the United Kingdom, the differentials are considerably larger. A tighter fiscal

${ }^{30} \mathrm{OECD}$ (1999c) finds a negative relation between the strictness of labor market regulation and the employment population ratio across OECD countries.

${ }^{31}$ See, for example, van Lowel (2000). Brandolini and others (2000) find that the relationship between job and worker flows appears to have changed in the early 1990s: for given rates of job creation and destruction, workers' entries and exits have increased, suggesting that the rotation of workers employed in existing positions accounts for a growing part of total worker turnover. They argue that this tendency may reflect the more extensive use of temporary contracts. 
policy stance is the most important demand-side factor that slowed Italy's growth in the $1990 \mathrm{~s}$; for the subperiod 1996-98, however, it is Italy's larger exchange rate appreciation.

55. Clearly, the results from the OEF simulations need to be treated with caution. First, the OEF model is a crude approximation of the Italian economy; and second, pursuing policies comparable to those adopted by France, the Netherlands, and the United Kingdom was not an option for Italy without foregoing the benefits of EMU, with likely adverse implications for interest rates and risk premia. Even so, the results suggest that macroeconomic policies can at best explain part of Italy's slower growth relative to the Netherlands or the United Kingdom over the past decade.

56. The starting point for investigating structural growth impediments is a standard growth accounting exercise. The results suggest that Italy has been lagging the Netherlands and the United Kingdom mainiy with respect to employment creation. Italy's comparatively modest research and development expenditure, lagging educational achievements, and more sheltered product markets are not reflected in a considerably lower contribution by total factor productivity to growth over the long run, perhaps because of progress achieved in these areas over the sample period. Similarly, the contribution of capital does not differ much from that in the comparator countries, although it has been declining in the $1990 \mathrm{~s}$. The evidence from the accounting exercise thus suggests that a closer investigation of labor market developments may be key to understanding Italy's structural growth differential. Assessing the extent of labor market distortions requires an analysis of structural demand-and supply-side developments.

57. Structural demand-side developments in labor markets suggest that labor demand may have declined in all countries except for the United Kingdom. Upon allowing for costs in adjusting factor proportions and an elasticity of factor substitution less than one, the results suggest that France and Italy suffered an about 5-10 percentage point larger demand decline than the Netherlands, which was concentrated in the 1990s. A more efficient use of labor resources, following improved labor relations, and a smaller increase in wage differentiation could explain the more rational use of labor and employment losses in Italy.

58. Characterizing structural labor supply by a standard wage-setting relation reveals that suppiy expanded in all countries, but to a much lesser degree in Italy. Dutch labor appears to have conceded large labor cost reductions, amounting to almost 15 percent at any given level of unemployment or nonemployment over the past 15 years. French labor too conceded cuts in compensation, albeit to a lesser extent. By contrast, for Italy as a whole, there is no evidence for labor cost reductions on a Dutch or French scale. Some moderation is detectable in data for the center-northern region of the country, suggesting Italy's labor market problems have a regional dimension. An analysis of regional labor market evolutions reveals that rigidities, stemming from country-wide sectoral wage bargaining, prevented real wages in the South from declining relative to those in the Center-North, to the extent required by the worsening labor market conditions. 
59. Reforms to wage bargaining have played an important role in moderating wage growth in the face of adverse labor demand conditions. In the Netherlands, the Wassenaar agreement of November 1982 proved pivotal. A similar agreement helped contain wage costs in Italy. However, it c8me ten years later during 1992/93 and, while it has delivered labor cost reductions, these are not of a scale similar to that of the Netherlands since 1982.

60. Why has there been less of a labor supply increase, as evidenced by a smaller labor cost decline at given unemployment or nonemployment rates in Italy? Was it related to developments intrinsic to labor markets, such as militant trade unions, or to external factors? Available evidence suggests that industrial relations and labor market regulations have jmproved considerably over the past two decades. The argument developed here is that Italy experienced a sharp increase in the tax burden on labor during the 1980s and 1990s, quite in contrast to the comparator countries. While most of the evidence in the literature suggests that in the long run labor tax increases are reflected in lower after-tax pay rather than less employment and more unemployment, the 13 percentage point increase in effective labor taxes during 1980-96-almost half of which took place in the 1990s-likely reverberated strongly until recently. Although take-home consumption wages may well have declined in real terms for many workers during the $1990 \mathrm{~s}$, tax and contribution increases limited the effect of moderation on the real gross product wages, which matter for employment.

61. Looking ahead, the growth prospects for Italy should be better, considering that the fiscal stance becomes neutral and labor taxation is expected to level off. The performance of employment has already improved remarkably. However, considering the high unemployment and low labor force participation rates in Italy, there remains a case for continued wage moderation. Wage moderation, in turn, could be facilitated by lowering the taxation of labor income. Finally, containing labor costs will be particularly important in the South, where unemployment rates exceed 20 percent: while by no means the solution to the "southern problem," it would facilitate a rapid turnaround in southern GDP growth, such as targeted in the new Mezzogiorno development program. 
Table 1. Italy: Growth Performance, 1980-99

$1980-89 \quad 1990-99 \quad 1996-99$

(Annual percentage change, unless otherwise indicated)

\section{Real GDP}

$\begin{array}{llll}\text { France } & 2.4 & 1.7 & 2.3 \\ \text { Italy } & 2.4 & 1.4 & 1.5 \\ \text { Netherlands } & 1.9 & 2.9 & 3.5 \\ \text { United Kingdom } & 2.4 & 1.9 & 2.6\end{array}$

Real GDP, business $1 f$

$\begin{array}{lrrr}\text { France } & 2.3 & 1.8 & 2.5 \\ \text { Italy } & 2,5 & 1.5 & 1.4 \\ \text { Netheriands } & 1.9 & 3.0 & 3.7 \\ \text { United Kingdom } & 2.9 & 2.5 & 2.8 \\ & & & \\ \text { Employment 1/ } & & & \\ & & & \\ \text { France } & 0.2 & 0.3 & 0.9 \\ \text { Italy } & 0.2 & -0.1 & 0.8 \\ \text { Netherlands } & 0.7 & 2.1 & 2.7 \\ \text { United Kingdom } & 0.6 & 0.2 & 1.2 \\ & & & \\ \text { Government employment } 1 / & & & \\ \text { France } & & 0.8 & 0.3 \\ \text { Italy } & 1.5 & -0.3 & -0.5 \\ \text { Netherlands } & 1.4 & -0.1 & 0.3 \\ \text { Urited Kingdorn } & 0.6 & -3.6 & -0.4\end{array}$

Capital stock business sector $1 /$

\begin{tabular}{llll} 
France & 2.7 & 2.4 & 2.2 \\
Italy & 2.9 & 2.8 & 2.7 \\
Netherlands & 1.7 & 2.4 & 2.8 \\
United Kingdom & 1.7 & 2.8 & 3.1 \\
\hline
\end{tabular}

Sourse: IMF, World Economic Outlook database, uniess otherwise noted.

1/ Source: OECD Economic Outlook database. 
Table 2. Italy: Demographics and Growth, 1980-99

$1980-89 \quad 1990-99 \quad 1996-99$

Working age population growth

$\begin{array}{lllr}\text { France } & 0.9 & 0.4 & 0.4 \\ \text { Italy } & 0.7 & 0.1 & -0.1 \\ \text { Netherfands } & 1.1 & 0.5 & 0.4 \\ \text { United Kingdom } & 0.5 & 0.3 & 0.3\end{array}$

Labor force participation rate

$\begin{array}{lrrr}\text { France } & 67.0 & 67.0 & 67.4 \\ \text { Italy } & 59.2 & 57.7 & 57.6 \\ \text { Netherlands } & 57.0 & 61.6 & 63.9 \\ \text { United Kingdom } & 74.7 & 75.6 & 75.4 \\ & & & \\ \text { Unemployment rate } & & & \\ & & & \\ \text { France } & 9.0 & 11.2 & 11.9 \\ \text { Italy } & 8.4 & 10.7 & 11.8 \\ \text { Netherlands } & 8.0 & 5.8 & 4.9 \\ \text { United Kingdom } & 9.5 & 8.0 & 6.8\end{array}$

Real GDP per person of working age

\begin{tabular}{llll} 
France & 1.4 & 1.4 & 1.9 \\
Italy & 1.7 & 1.3 & 1.5 \\
Netherlands & 0.8 & 2.4 & 3.1 \\
United Kingdom & 1.9 & 1.6 & 2.2 \\
\hline
\end{tabular}

Sources: IMF; OECD Economic Outlook database. 
Table 3. Italy: Simulating Identical Fiscal and Manetary Policy Stance, 1992-98

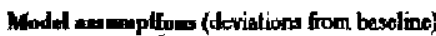

Elesticity of ODR w.I.t governsent costumuption +1 peroent of ODP

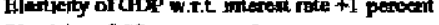

Blasticity of ODP w.r.te exchange mate t1 parom

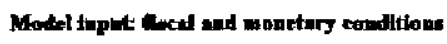

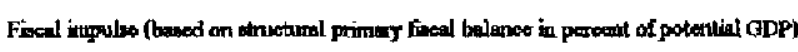

\section{Frence}

Hatly

Netherlands

Unitod Kingdon

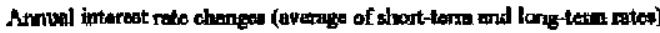

\section{Itobly}

Italy

United Kingiom

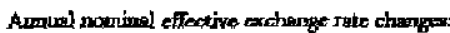

Franco

linty

United Xigigoton

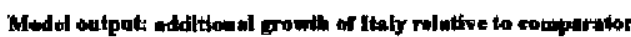

Seme neal hanee

Franco

Nothortends

United Kinglom

Seme interest nato changer

Frence

Neathertands

Unitoot Kinghom

Bame nowinal exchenger rete chenow

Finnce

Wethotands

Uniled Kingedorn

\begin{tabular}{|c|c|c|c|c|c|c|c|}
\hline $\mathbf{T}$ & $\mathrm{T}+\mathbf{L}$ & $T+2$ & $\mathrm{~T}+3$ & $T+d$ & $T+5$ & $T+6$ & \\
\hline 0.9 & 0.7 & 0.7 & 0.5 & 0.6 & a.d & 0.3 & \\
\hline-0.3 & -0.7 & -0.9 & +1.1 & -1.2 & -1.2 & -1.2 & \\
\hline-0.2 & 01 & -0.1 & -0.1 & 0.0 & 0.0 & t.0 & \\
\hline 92 & 1993 & 1994 & 1995 & 1926 & ותופו & 1998 & Avermos \\
\hline
\end{tabular}

$\begin{array}{rrrrrrrrr}1.6 & -0.4 & -0.1 & 0.0 & -1.7 & -0.8 & 0.6 & -0.1 & \ldots \\ -2.4 & -1.6 & 0.7 & -1.6 & -0.7 & -2.5 & 1.2 & -1.0 & \ldots \\ 0.4 & -1.8 & 0.9 & -0.2 & -1.9 & 0.2 & 0.3 & -0.3 & \ldots \\ 1.3 & 0.8 & -0.6 & -0.2 & -1.1 & -2.0 & -1.7 & -0.5 & \ldots\end{array}$

$\begin{array}{rrrrrrrrr}-0.3 & -2.0 & -0.7 & -0.3 & -1.2 & -0.4 & -0.2 & -0.7 & \ldots \\ 1.0 & -3.0 & -1.2 & 1.8 & -2.5 & -2.3 & -1.9 & -1.1 & \ldots \\ -0.3 & -1.1 & -1.5 & -0.4 & -1.1 & -0.2 & -0.4 & -0.7 & \ldots \\ -1.5 & -2.6 & 0.2 & 0.6 & -0.5 & 0.0 & -0.5 & -0.6 & \ldots\end{array}$

$\begin{array}{rrrrrrrrr}3.2 & 3.5 & 0.9 & 3.4 & -0.1 & -3.2 & 0.5 & 1.1 & \ldots \\ -3.1 & -15.1 & -4.4 & -9.8 & 9.3 & 0.7 & -0.4 & -3.6 & \ldots \\ 2.3 & 3.1 & 0.3 & 1.0 & -1.9 & -4.6 & -0.1 & 0.4 & \ldots \\ -3.8 & -8.3 & 0.3 & -4.9 & 1.7 & 16.5 & 3.4 & 0.4 & \ldots\end{array}$

Sonree: Find staff estimates

(C)International Monetary Fund. Not for Redistribution 
Table 4. Italy: Decomposing Growth Differentials, 1992-98

\begin{tabular}{|c|c|c|c|c|}
\hline & $\begin{array}{c}\text { Average 1992-98 } \\
\text { Model }\end{array}$ & $\begin{array}{c}\text { Average 1996-98 } \\
\text { Model }\end{array}$ & $\begin{array}{c}\text { Average 1992-98 } \\
\text { Actual }\end{array}$ & $\begin{array}{c}\text { Average } 1996-98 \\
\text { Actual }\end{array}$ \\
\hline \multicolumn{5}{|c|}{ Additional growth of Italy relative to comparator counuries; } \\
\hline $\begin{array}{l}\text { France } \\
\text { of which: fiscal impulse } \\
\text { monetary policy } \\
\text { exchange rate }\end{array}$ & $\begin{array}{c}0.4 \\
0.5 \\
-0.2 \\
0.0\end{array}$ & $\begin{array}{c}0.8 \\
-0.3 \\
-0.6 \\
1.6\end{array}$ & 0.2 & 0.7 \\
\hline $\begin{array}{l}\text { Netherlands } \\
\text { of which: fiscal impulse } \\
\text { nonetary policy } \\
\text { exchange rate }\end{array}$ & $\begin{array}{c}0.3 \\
0.4 \\
-0.2 \\
0.1\end{array}$ & $\begin{array}{r}1.0 \\
-0.1 \\
-0.6 \\
1.8\end{array}$ & 1.3 & 2.0 \\
\hline $\begin{array}{l}\text { United Kingdom } \\
\text { of which: fiscal impuise } \\
\text { roonetary policy } \\
\text { exchange rate }\end{array}$ & $\begin{array}{l}-0.4 \\
0.2 \\
-0.2 \\
-0.3\end{array}$ & $\begin{array}{l}-2.3 \\
-1.1 \\
-1.1 \\
-0.1\end{array}$ & 1.2 & 1.3 \\
\hline
\end{tabular}

Source: Fund staff estimates. 
Table 5. Italy: Product Market Regulation

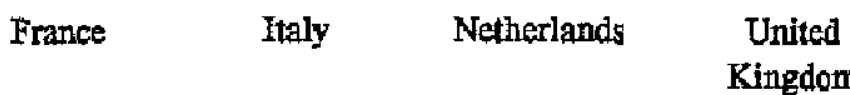

\section{Overall}

Product market regulation

2.1

1.2

2.7

2.6

2.7

Barriers to entrepreneurship

B. Functional

Economic regulation

Adrainistrative regulation
2.3

3.1
2.3

0.8

3.3

3.9

2.7

3.5

3.0
1.4

0.7

1.8

0.4

0.5

2.3

0.6

1.4

0.5

2.1

1.5

0.6

0.5

Source: Nicoletti and others (1999). The ranking spans $0-6$, with 6 indicating the most restrictive level. Rankings were determined on the basis of responses to an extensive questionnaire distributed to OECD member countries in 1998. The questionnaire asked for information on more than 1,500 regulatory provisions. The sectors included retail distribution, transportation (road freight, air passenger transport, and rail transport), and telecommunications. 
Table 6. Italy: Educational Attainment and Expenditure, 1995-96

\begin{tabular}{|c|c|c|c|c|c|c|c|c|c|c|}
\hline & \multicolumn{5}{|c|}{ At least upper secondary education, 1996} & \multicolumn{5}{|c|}{ At least university-level education, 1996} \\
\hline & Ages 25-64 & Ages 25-34 & Ages 35-44 & Ages 45-54 & Ages 55-64 & Ages 25-64 & Ages 25-34 & Ages 35-14 & Ages 45-54 & Ages 55-64 \\
\hline France & 60 & 74 & 64 & 56 & 38 & 10 & 12 & 10 & 10 & 5 \\
\hline Italy & 38 & 52 & 46 & 31 & 17 & $\mathbf{8}$ & 8 & 11 & 8 & 5 \\
\hline Netherlands & 63 & 72 & 66 & 57 & 47 & 23 & 25 & 25 & 21 & 16 \\
\hline \multirow[t]{3}{*}{ United Kingdom } & 76 & 87 & 81 & 71 & 60 & 13 & 15 & 15 & 12 & $\mathbf{8}$ \\
\hline & \multicolumn{5}{|c|}{ Fixpenditure per student, $19951 /$} & & & & & \\
\hline & Child & Primary & Secondery & Tertiary & Combined & & & & & \\
\hline France & 3,242 & 3,379 & 6,182 & 6,569 & 5,001 & & & & & \\
\hline Italy $1 /$ & 3,316 & 4,673 & 5,348 & 5,013 & 5,157 & & & & & \\
\hline Netherlands & 3,0121 & 3,191 & 4,351 & 9,026 & 4,397 & & & & & \\
\hline United Kingdom 2/ & 5,049 & 3,328 & 4,246 & 7,225 & 4,222 & & & & & \\
\hline
\end{tabular}

Source: Modified versions of Tables A1.2a and B4, 1 from OECD (1998)

1/ Converted In U.S. dollars using PPPS, on public and private institutions (based on full-lime equivalents).

2/ Public institutions. 
Table 7. Italy: Selected R\&D Indicators, 1997-98

Budget appropriations (in percent of GDP), 1997

France

Italy

0.62

Netherlands

0.82

United Kingdom

0.75

Employment in high-tech sectors (in percent of total), 1998

France

Italy

Netherlands

United Kingdom

European patent applications (per million persons), average 1989-98
10.6

10,1

8.2

11.5

Level Growth Rate

France

95.5

1.9

Italy

Netheriands

45.9

United Kingdom

121.1

Source: Eurostat. 
Table 8. Italy: Labor Taxation, 1980-96

$\begin{array}{lrrrr}\text { Average effective tax rates on labor, 1980-96 l/ } & & \\ & 1980 & 1985 & 1990 & 1996 \\ \text { France } & 36 & 40 & 42 & 45 \\ \text { Italy } & 26 & 30 & 33 & 39 \\ \text { Netherlands } & 44 & 47 & 47 & 44 \\ \text { United Kingdom } & 25 & 24 & 22 & 22\end{array}$

Income tax plus employee and employee contribution $2 f$

$\begin{array}{lrrrrrr} & 1979 & 1985 & 1991 & 1994 & 1996 & 19993 / \\ \text { France } & \ldots & \ldots & \ldots & 51.6 & 49.7 & 47.9 \\ \text { Italy } & 45.3 & 50.0 & 48.8 & 49.9 & 50.8 & 47.3 \\ \text { Netherlands } & 48.0 & 49.9 & 46.5 & 45.6 & 43.8 & 44.4 \\ \text { United Kingdom } & 36.1 & 37.8 & 33.2 & 33.3 & 32.6 & 31.0\end{array}$

Marginal tax pedges on earned income-selected income levels, 1996

\begin{tabular}{lcccccccccc} 
& \multicolumn{3}{c}{ Single-no children } & \multicolumn{3}{c}{ Head earner-2 children } & \multicolumn{3}{c}{ Spouse-2 children } \\
$\begin{array}{l}\text { Wage level in percent of } \\
\text { average production worker }\end{array}$ & 67 & 100 & 167 & $100-0$ & $100-33$ & $100-67$ & $100-0$ & $100-33$ & $100-67$ \\
& & & & & & & & & \\
France & 52.1 & 55.1 & 54.9 & 46.4 & 45.4 & 49.6 & 43.2 & 43.2 & 47.7 \\
Italy & 55.1 & 59.4 & 57.6 & 59.4 & 59.4 & 59.4 & 38.4 & 52.0 & 55.1 \\
Netherlands & 52.2 & 57.5 & 50.0 & 46.9 & 57.5 & 57.5 & 11.1 & 42.7 & 52.2 \\
United Kingdom & 38.3 & 40.1 & 31.0 & 40.1 & 40.1 & 40.1 & 0.0 & 32.0 & 38.3 \\
& & & & & & & & & \\
\hline
\end{tabular}

Source: OECD (1999a and 1999b).

1/ These effective tax rates are based on measured tax revenue and income. Average effective tax rates on labor are estimated as household incone taxes and social security contributions of employees, employers, and the self-employed divided by total compersation of employees plus self-employed Iabor income.

2/ In percent of labor costs, for a single person without children. For Ttaly, as of 1990, data have been revised to include only production workers (exchuding employees). Also, the declire in the tax wedge in 1999 reflects to an important extent the replacement of employer-paid heidth contributions (and various other smaller taxes) by a tax on firms' value added (IRAP).

3/ Estímates. 
Tuble 9. Italy: Capital Taxation, 1980-98

Average effective tax rates on capital (based on gross operating surphus), 1980-96 W/

$\begin{array}{lrrrr} & 1980 & 1985 & 1990 & 1996 \\ \text { France } & 21 & 22 & 21 & 20 \\ \text { Italy } & 19 & 22 & 26 & 30 \\ \text { Netherlands } & 21 & 16 & 19 & 21 \\ \text { United Kingdom } & 43 & 46 & 42 & 39\end{array}$

Marginal bax wedges on investment, personal, and corporate systems, 1991-98 2/

\begin{tabular}{|c|c|c|c|c|c|c|c|c|}
\hline \multirow[t]{2}{*}{ Country } & \multirow[t]{2}{*}{ Year } & \multicolumn{3}{|c|}{ Sources of finarsing $3 /$} & \multicolumn{3}{|c|}{ Physical assets 4/ } & \multirow{2}{*}{$\begin{array}{c}\text { Overall weighted } \\
\text { awerage }\end{array}$} \\
\hline & & Eamings & Equity & Debt & Machinery & Euilding & Inventoties & \\
\hline \multirow[t]{3}{*}{ France } & 1901 & 2.7 & 6.4 & -0.1 & 1.2 & 2.1 & 4.0 & 21 \\
\hline & 1996 & 3.5 & 6.2 & $\ldots$ & 23 & 2.4 & 2.1 & 23 \\
\hline & 1998 & 4.4 & 8.5 & 0.8 & 2.6 & 4.1 & 4.8 & 3.5 \\
\hline \multirow[t]{3}{*}{ Italy } & 1991 & 4.5 & 2,9 & -0.8 & 2.6 & $\mathbf{3 . 1}$ & 1.7 & 2.5 \\
\hline & 1996 & 5.9 & 5.3 & $\ldots$ & 2.6 & 3.4 & 6.9 & 3,8 \\
\hline & 1998 & 2.2 & 2.5 & 0.6 & 1.0 & 1.8 & 3.1 & 1.7 \\
\hline \multirow[t]{3}{*}{ Netherlands } & 1991 & 0.5 & 6.5 & 2.9 & 1.8 & 2.2 & 20 & 1.9 \\
\hline & 1996 & 0.5 & 6.2 & $\ldots$ & 1.7 & 2.2 & 2.0 & 1.9 \\
\hline & 1998 & 0.6 & 6.3 & 3.0 & 1.8 & 2.3 & 2.0 & 2.0 \\
\hline \multirow[t]{3}{*}{ United Kingdom } & I991 & 1.9 & 1.3 & 2.4 & 1.5 & 1.6 & 3.8 & 2.0 \\
\hline & 1996 & 2,3 & 3.1 & $\ldots$ & 1,8 & 2.1 & 3.4 & 22 \\
\hline & 1998 & 2.2 & 2.8 & 1.8 & 1.7 & 2.1 & 3.1 & 2.2 \\
\hline
\end{tabular}

Sources: OFCD (2000a); and Carey and others (2000), forthcoming OECD Working Paper.

1/ The average effective tax rates are based on measaured tax rovenue and income. Avernge effective tax rates cal capital ane extimated as honsehold tares

(including unalocated social security contributions between enployees, employers, and the self-enployed) paid on self-employment and property income received

by houschalds less imputed wages for the self-employed, phis corporate taxes, taxos on property and divided by the operating surplus of the economy less wages of the self-employed.

$2 /$ These indicators show the degree to which the personal and corporate tax systems scale up (or down) the real pre-tax nate of netam that must be camed

on an investment, given that the household can eam a 5 percent real rate of return on a demand deposit.

3/The weights are: msclinery 0.50 , buildings 0.28 , and inventories 0.22 .

4/ The weights are: retained eamings 0.55 , new equify 0.10 , and debt 0.35 . 
Table 10a. Italy: Labor Market Regulation

\section{Late 1980s Late 1990s}

\section{Strictness of protection against individual dismissals}

$\begin{array}{lll}\text { France } & 2.5 & 2.6 \\ \text { Italy } & 3.1 & 3.1 \\ \text { Netherlands } & 3.2 & 3.4 \\ \text { United Kingdom } & 1.2 & 1.2\end{array}$

Strictness of temporary and fixed-term employment regulation

France

Netherlands

United Kingdom

Increase in strietness for collective relative to individual dismissals

France

2.1

Italy

-.. 4.1

Netherlands

2.8

United Kingdom

… 2.9

Overall strictness of employment protection legislation

France

Source: OECD (1999c). The summary scores can range from 0 to 6 , with higher values representing more strict regulation.

1/ For late 1990s but excluding collective dismissal regulation.

2/ For late 1990s including collective dismissal regulation. 
Table 10b. Italy: Labor Market Regulation, 1989-94

$1989-94$

Benefit replacement rate (in percent)

France

57.0

Italy

20,0

Netherlands

70.0

United Kingdom

38.0

Benefit duration (in years)

France

Italy

0.5

Netherlands

2.0

United Kingdom

4.0

Source: Nickell (1997).

CInternational Monetary Fund. Not for Redistribution 
Table 11. Italy: Center-North and South, 1980-99

$$
\text { 1981-89 }
$$

(Annual percentage change, unless otherwise indicated)

\section{Real GDP}

$\begin{array}{llll}\text { Itaiy } & 2.2 & 1.3 & 1.2 \\ \text { Center-North } & 2.2 & 1.4 & 1.4 \\ \text { South } & 2.3 & 0.8 & 0.7\end{array}$

Real GDP, business

italy

$\begin{array}{lll}2.5 & 1.4 & 1.2 \\ 2.5 & 1.6 & 1.4 \\ 2.5 & 0.9 & 0.6\end{array}$

South

1.4
0.6

Employment

Italy

Center-North

0.5

$-0.4$

0.2

South

0.5

$-0.3$

0.2

0.7

$-0.7$

0.0

Employment, nongovernment

Italy

Center-North

South

Gross fixed capital formation (in percent of GDP)

Italy

Center-North

South

Nominal Per capita GDP of South

Real GDP of South

Population of South
19.6

18.6

22.7

$-0.5$

0.3

$-0.3$

0.3

$-0.9$

0.2 
Table 12. Itaty: Growth Accounting, 1980-98 1/

\begin{tabular}{lcccc}
\hline & GDP & TFP & L & K \\
\hline 1990-98 & & & & \\
France & 1.7 & 0.8 & 0.0 & 0.9 \\
Italy & 1.5 & 0.7 & -0.2 & 1.0 \\
Netherlands & 3.0 & 1.0 & 1.1 & 0.9 \\
United Kingdom & 2.6 & 1.0 & 0.7 & 0.9 \\
& & & & \\
1980-89 & & & & \\
France & 2.3 & 1.7 & -0.1 & 0.8 \\
Italy & 2.5 & 1.2 & 0.4 & 0.9 \\
Netherlands & 1.9 & 1.0 & 0.2 & 0.6 \\
United Kingdom & 2.9 & 1.9 & 0.4 & 0.6 \\
& & & & \\
\hline
\end{tabular}

Source: OECD; for 1997 no data are available for the United Kingdom. GDP stands for real GDP, TFP for factor productivity, $L$ for employment, and $K$ for capital, all in the business sector. 
Table 13. Italy: Investment, 1980-99

$1980-89 \quad 1990-99 \quad 1996-99$

Capital stock in the business sector (annual average growth)

$\begin{array}{llll}\text { France } & 2.7 & 2.4 & 2.2 \\ \text { Italy } & 2.9 & 2.8 & 2.7 \\ \text { Netherlands } & 1.7 & 2.4 & 2.8 \\ \text { United Kingdoin } & 1.7 & 2.8 & 3.1\end{array}$

Private nonresidential fixed investment (in percent of business GDP)

$\begin{array}{llll}\text { Ftance } & 15.2 & 15.7 & 15.3 \\ \text { Italy } & 14.4 & 14.9 & 15.0 \\ \text { Netheriancis } & 15.9 & 16.6 & 17.1 \\ \text { United Kingdom } & 13.1 & 15.0 & 16.2\end{array}$

Private nomresidential fixed investment (in percent of capital)

$\begin{array}{llll}\text { France } & 5.7 & 5.7 & 5.5 \\ \text { Italy } & 5.3 & 5.1 & 5.0 \\ \text { Netherlands } & 5.8 & 6.6 & 6.9 \\ \text { United Kingdom } & 4.2 & 5.1 & 5.6\end{array}$

Private nomresidential fixed investment (contribution to business GDP growth)

$\begin{array}{llll}\text { France } & 0.5 & 0.2 & 0.6 \\ \text { ltaly } & 0.3 & 0.2 & 0.4 \\ \text { Netherlands } & 0.4 & 0.5 & 1.0 \\ \text { United Kingdom } & 0.8 & 0.6 & 1.5\end{array}$

Gross fixed capital formation (contribution to GDP growth)

$\begin{array}{llll}\text { France } & 0.8 & 0.3 & 0.9 \\ \text { Italy } & 0.6 & 0.3 & 0.8 \\ \text { Netherlands } & 0.5 & 0.8 & 1.6 \\ \text { United Kingdom } & 0.9 & 0.5 & 1.5\end{array}$

Source: OECD. 
Table 14. Italy: Regional Employment Growth, 1980-98

\begin{tabular}{|c|c|c|c|c|c|}
\hline & \multirow[t]{2}{*}{ Primary } & \multicolumn{2}{|c|}{ Secondary } & \multicolumn{2}{|c|}{ Tertiary } \\
\hline & & Total & $\begin{array}{c}\text { of which: } \\
\text { construction }\end{array}$ & Business & Nonbusiness \\
\hline & \multicolumn{5}{|c|}{ (In percent of total 1980 employment in the region) } \\
\hline \multicolumn{6}{|c|}{ Center-North } \\
\hline 1980-91 & -2.4 & -5.6 & -0.4 & 11.2 & 2.3 \\
\hline 1992-98 & -1.7 & -3.2 & -0.2 & 1.2 & -0.1 \\
\hline \multicolumn{6}{|l|}{ South } \\
\hline $1980-91$ & -5.9 & -1.9 & -0.3 & 12.5 & 4.6 \\
\hline $1992-98$ & -3.9 & -3.4 & -1.9 & -1.8 & -0.5 \\
\hline
\end{tabular}

Sources: ISTAT; and SVIMEZ.

CInternational Monetary Fund. Not for Redistribution 
Table 15. Italy: Earnings Differentials, 1995

\begin{tabular}{|c|c|c|c|c|}
\hline & France & Italy & Netherlands & United Kingdom \\
\hline Variance across professions $1 /$ & 47.1 & 62.2 & 23.7 & 36.9 \\
\hline \multicolumn{5}{|l|}{ Variance within professions; $1 /$} \\
\hline Corporate managers & 67.5 & 42,6 & 64.2 & 71.2 \\
\hline Managers of small enterprises & 52.0 & 39.1 & 35.4 & 69.3 \\
\hline Professionals & 50.3 & 39.5 & 53.4 & 48.6 \\
\hline Technicians and associate professionals & 54.3 & 45.5 & 48.3 & 79.1 \\
\hline Clerks & 43.2 & 32.0 & 38,4 & 35.0 \\
\hline Sales agents & 44.7 & 36.2 & 45.7 & 46.0 \\
\hline Craft and related workers & 45.8 & 25.4 & 46.0 & 33.2 \\
\hline Plant and machinc operators and assemblers & 39.4 & 37.2 & 38.5 & 36.9 \\
\hline Elementary occupations & 36.2 & 25.4 & 55.3 & 42.9 \\
\hline
\end{tabular}

Source: EUROSTAT, Struciure of Eamings Statistics, 1995.

l/ Standard deviation of average gross honrly earnings of listed professions divided by the average, in industry and markets services. 
Figure 1. Italy: Fiscal and Financial Indicators, 1990s
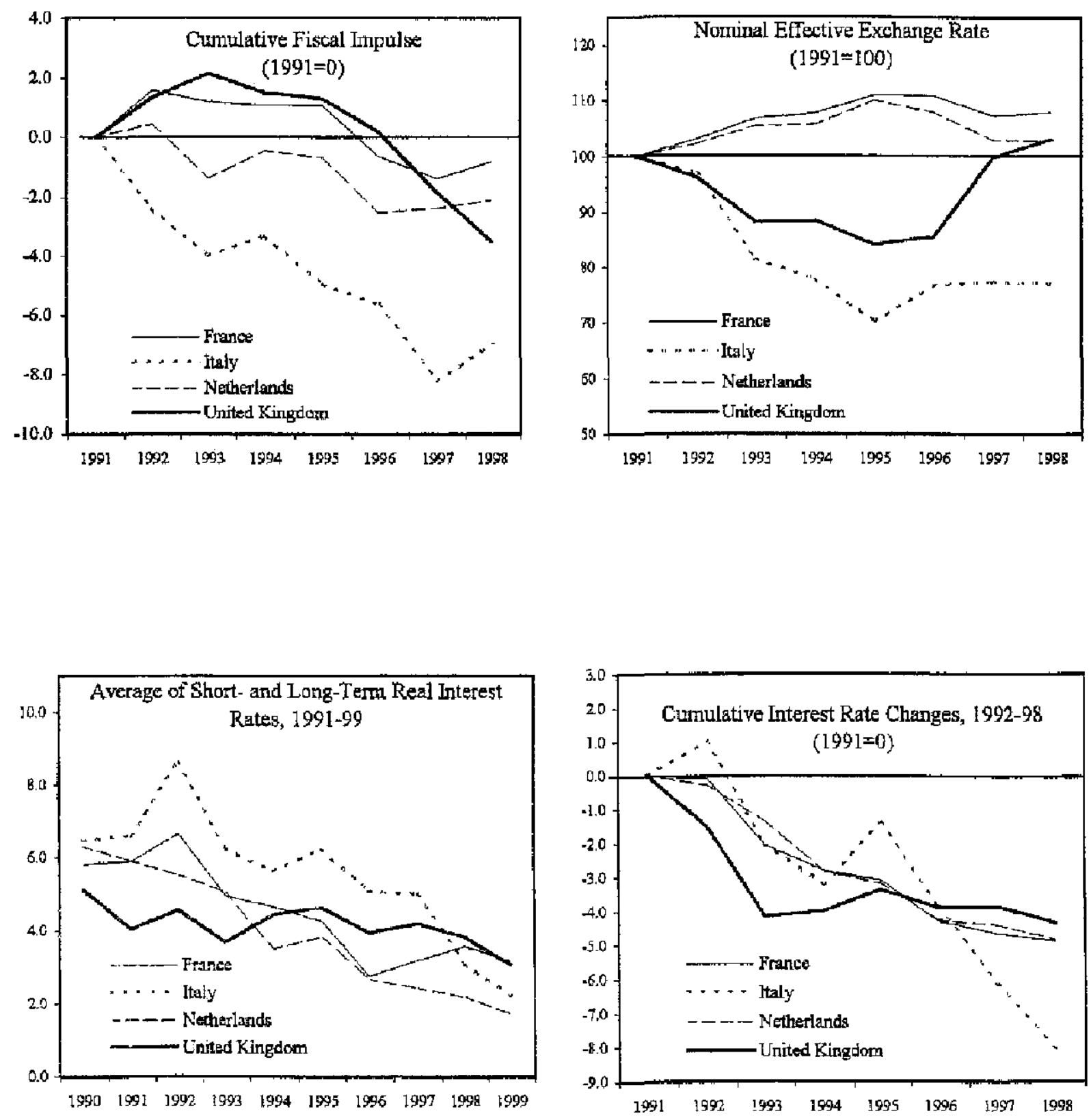

Sources: WEO Database; and Fund staff calculations. 
Figure 2. Italy: Capital-Output Ratios, 1980-98

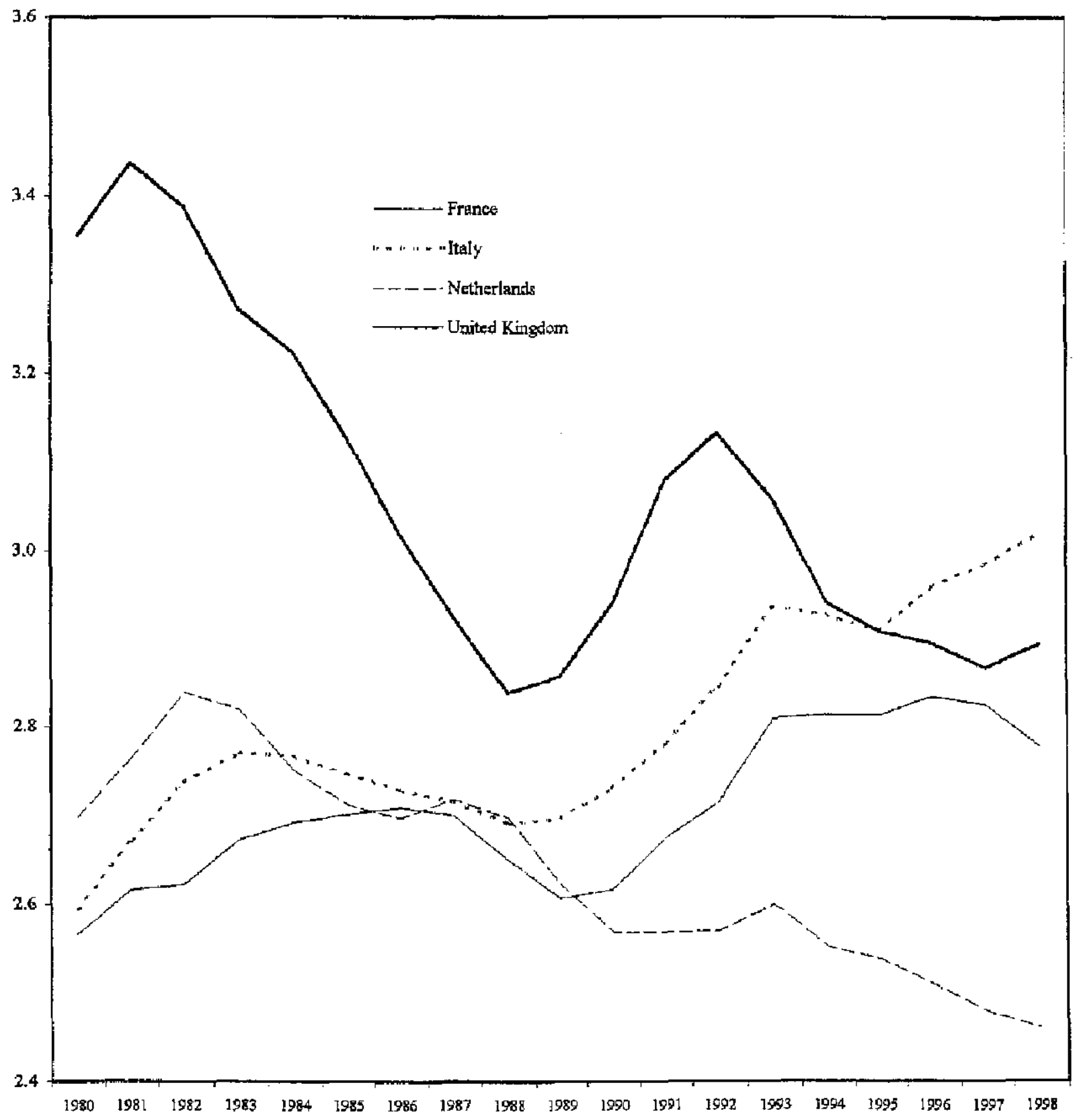

Sources: OECD; and Fund staff calculations. 
Figure 3a. Italy: Labor Costs, 1980-98
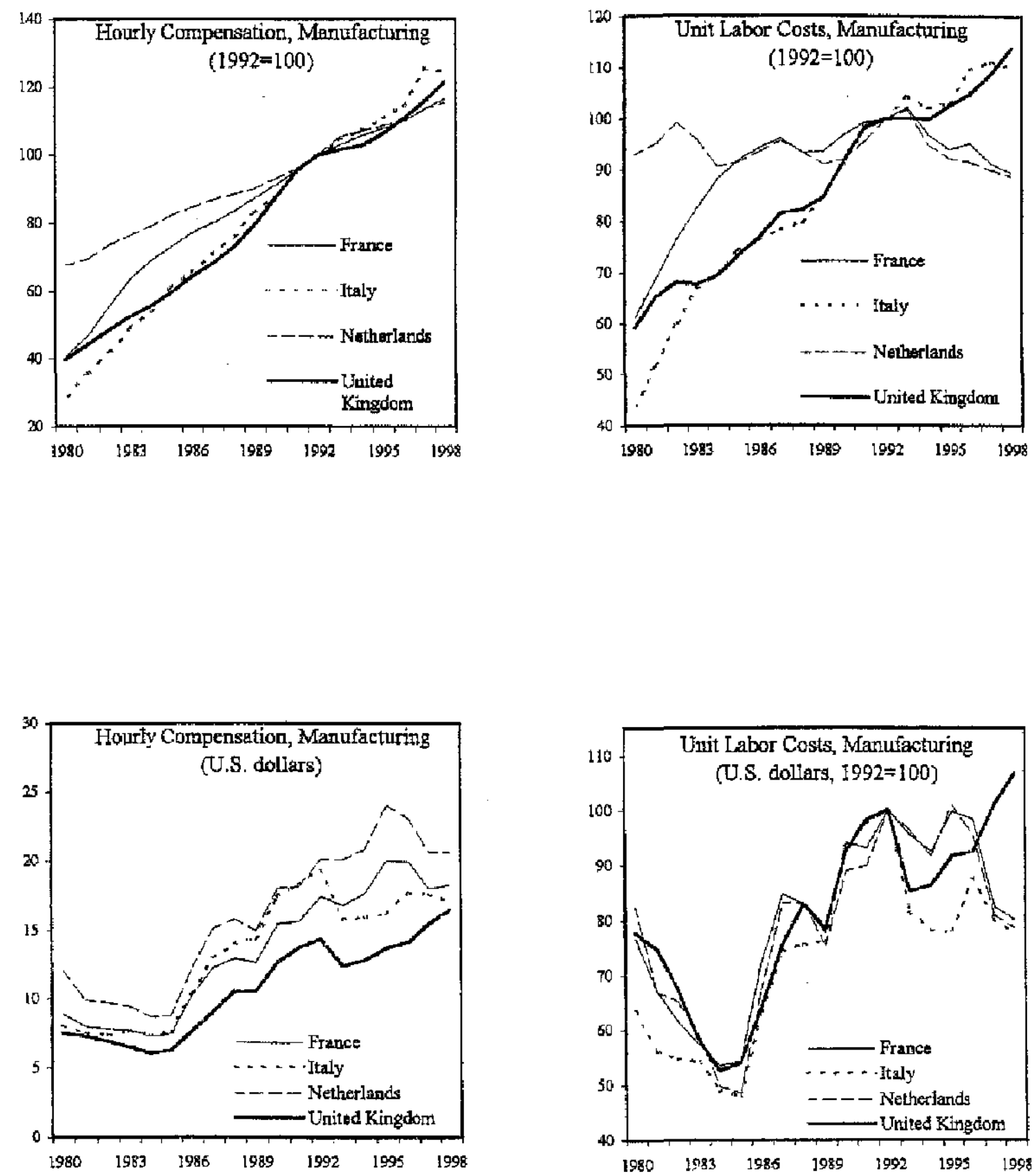

Source: Bureau of Labor Statistics. 
Figure 3b. Italy: Real Wages, 1980-98 1/

$(1990=100)$

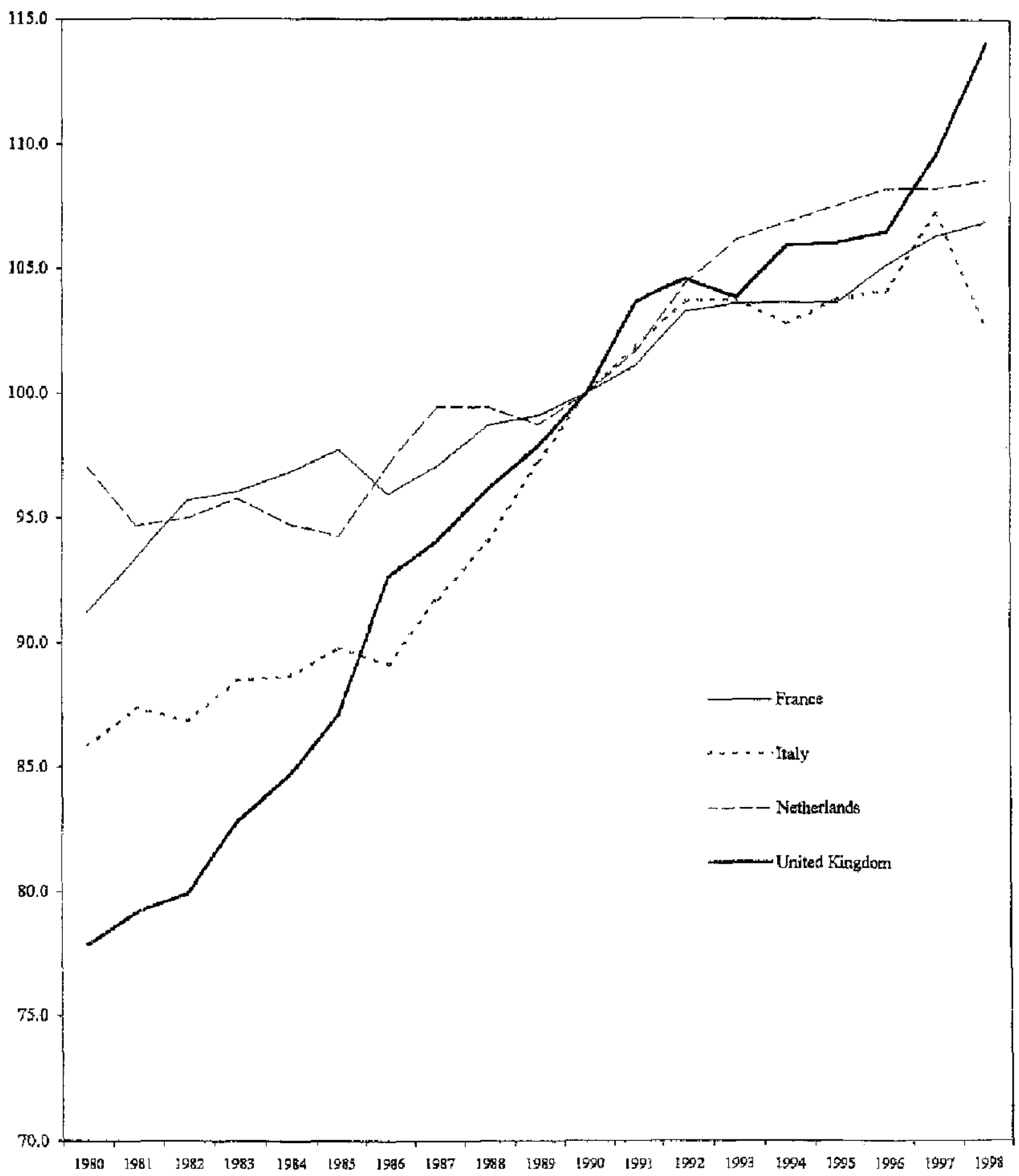

Sources: OECD; and Fund staff calculations.

$1 /$ Computed using business sector GDP deflator. 
Figure 4. Italy: Labor Supply Developments, 1980-98 1/
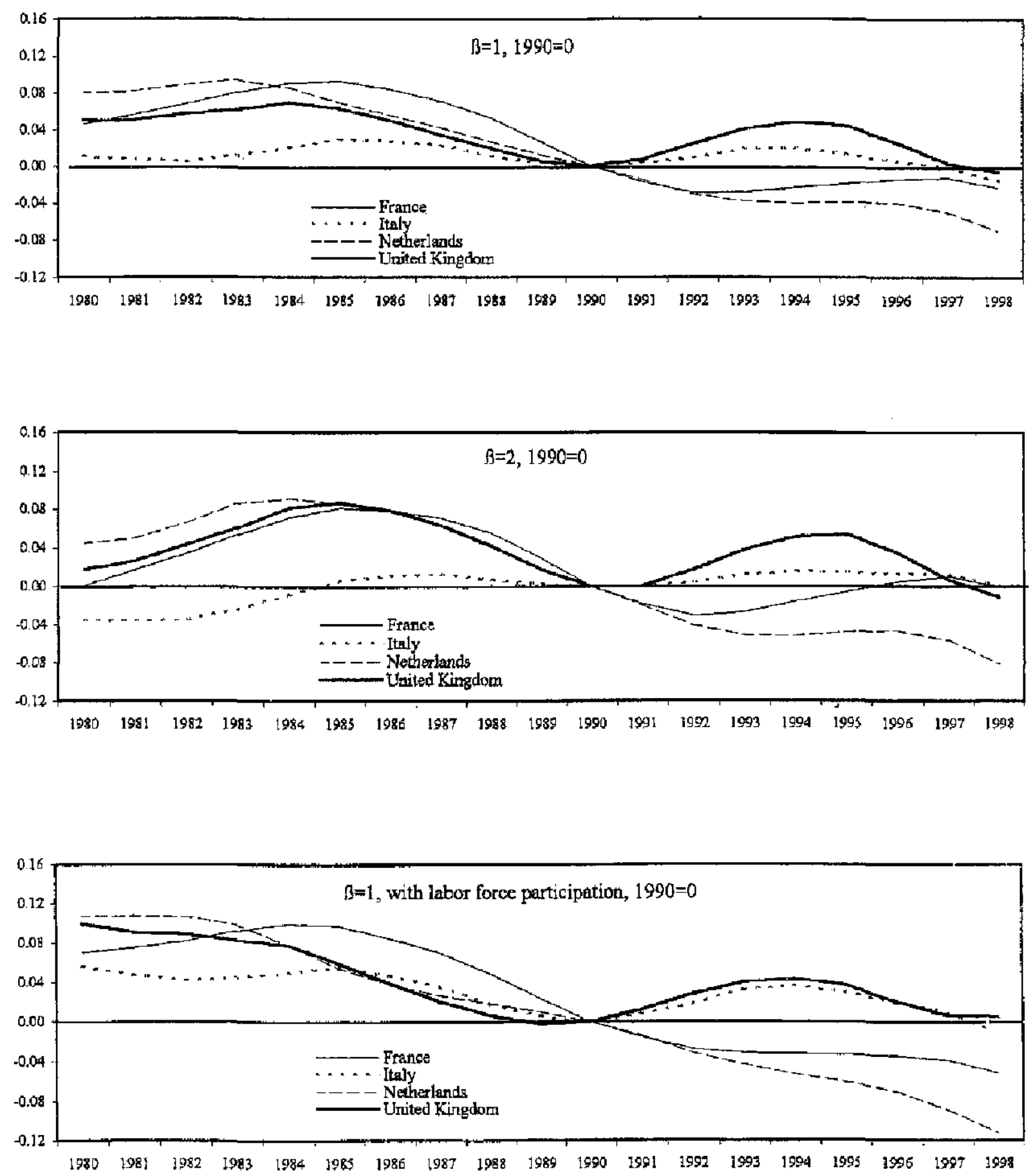

Sources: $O E C D$; and Fund staff calculations.

1/ Productivity-adjusted real wage at a constant unemployment or labor force participation rate. 
Figure 5. Italy: Labor Demand Developments, 1980-98
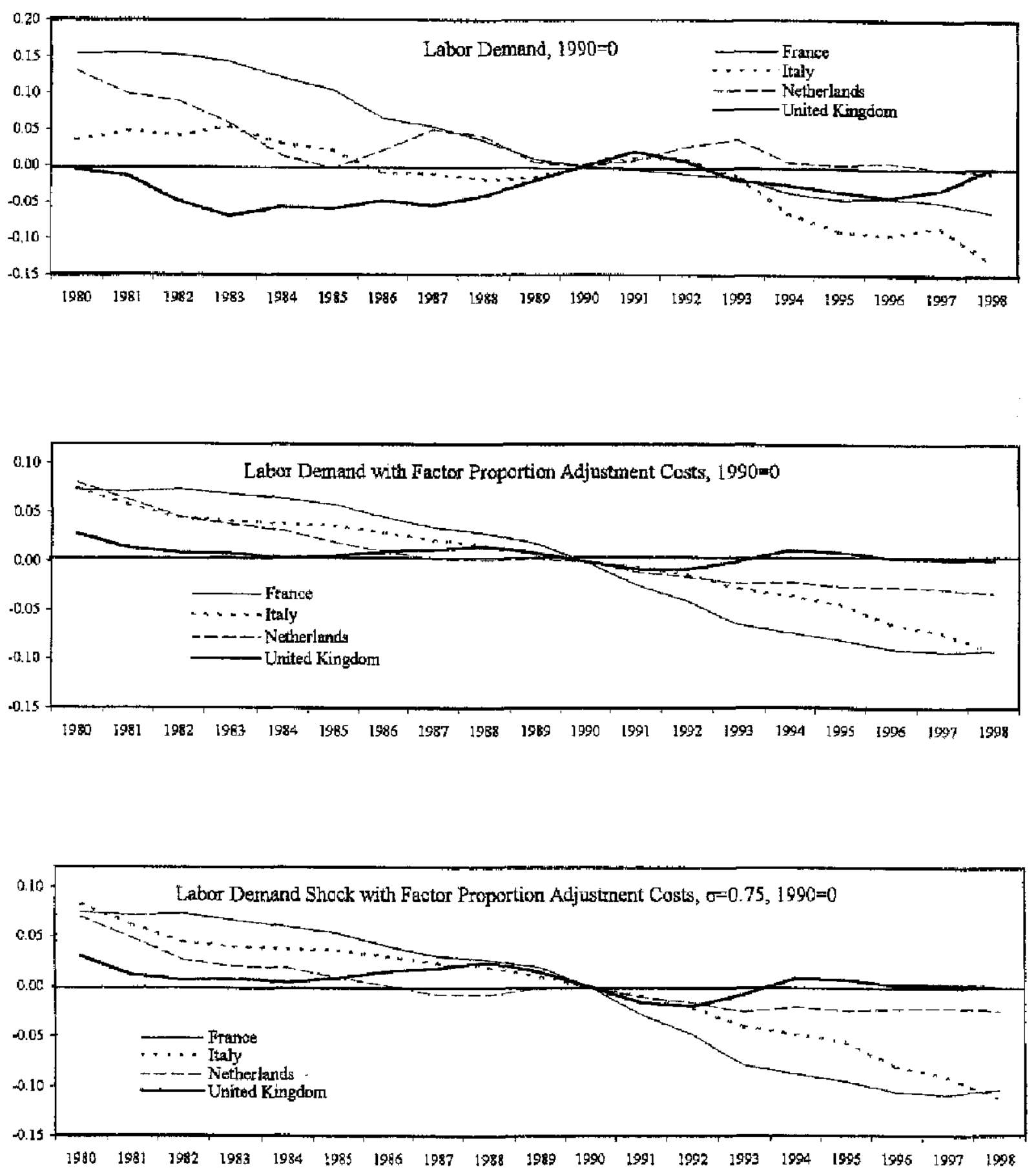

Sources: OECD; and Fund staff calculations. 
Figure 6. Italy: Regional Labor Demand and Supply Differences, 1980-98

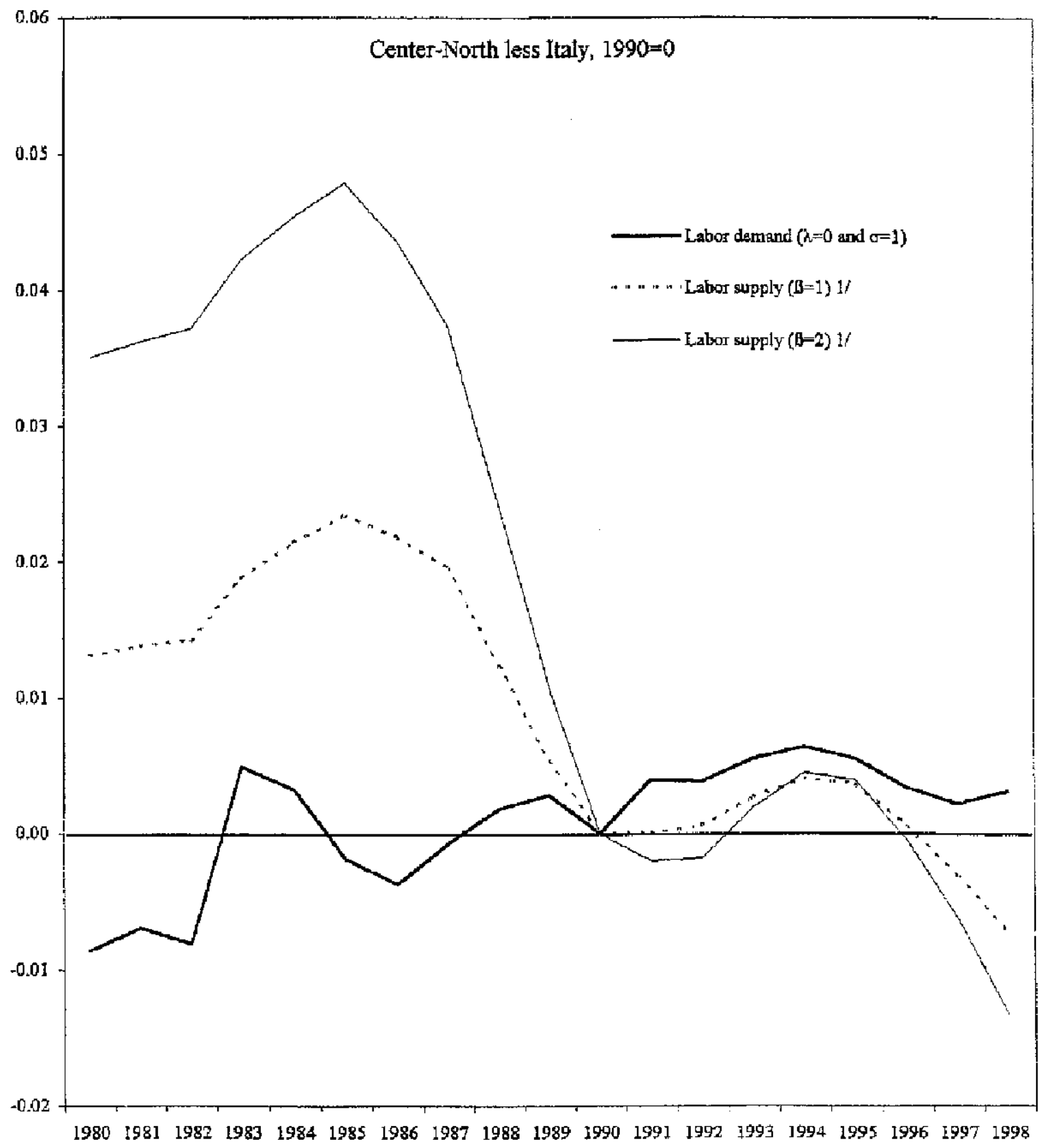

Sources: ISTAT; and Fund staff calculations.

1/ Productivity-adjusted real wage at a constant unemployment rate. 
Figure 7. Italy: Center-North and South, 1980-99
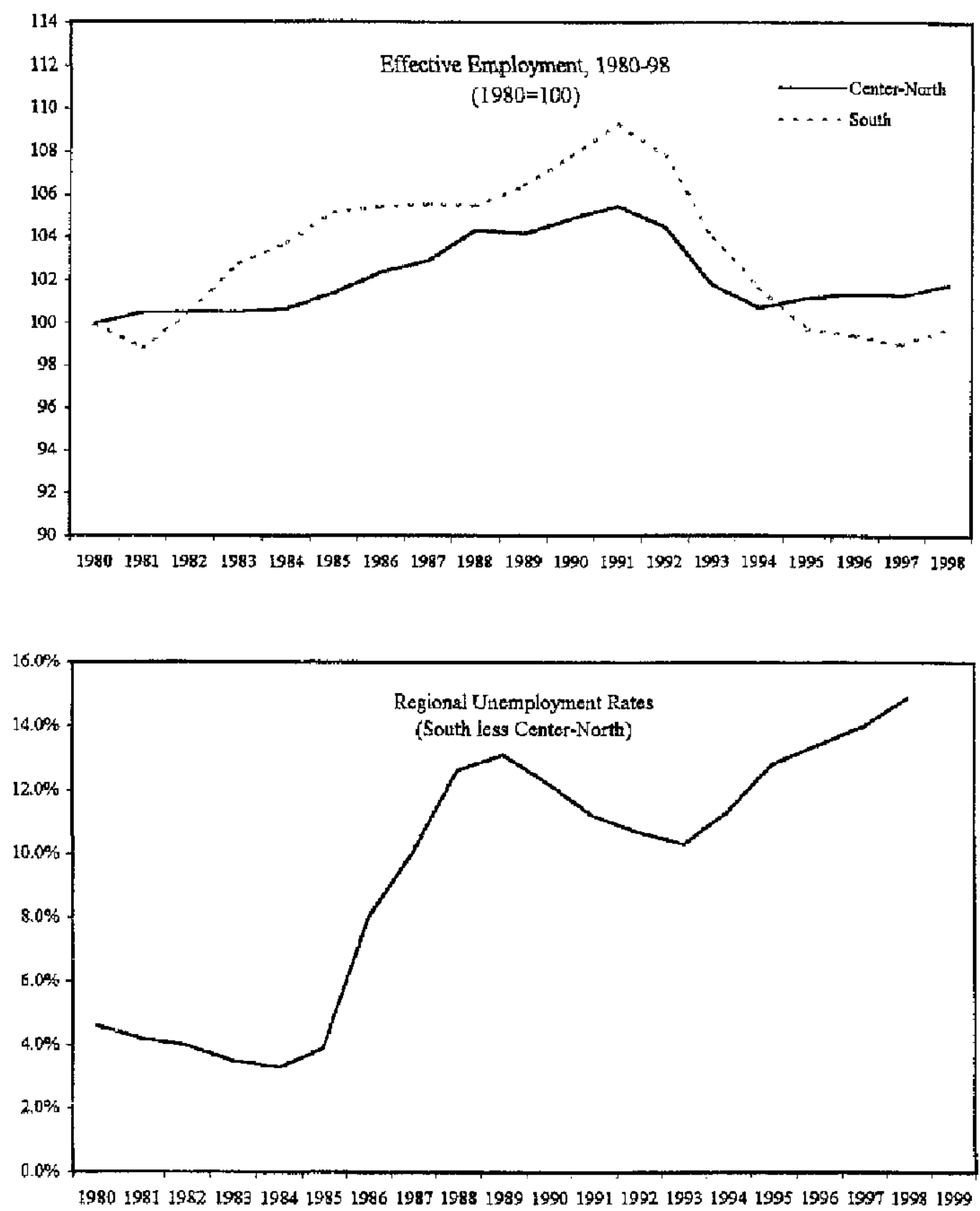

Soujces: ISTAT; SVIMEZ; and Bank of Italy. 
Figure 8. Itaty: Regional Labor Demand and Supply, 1980-98
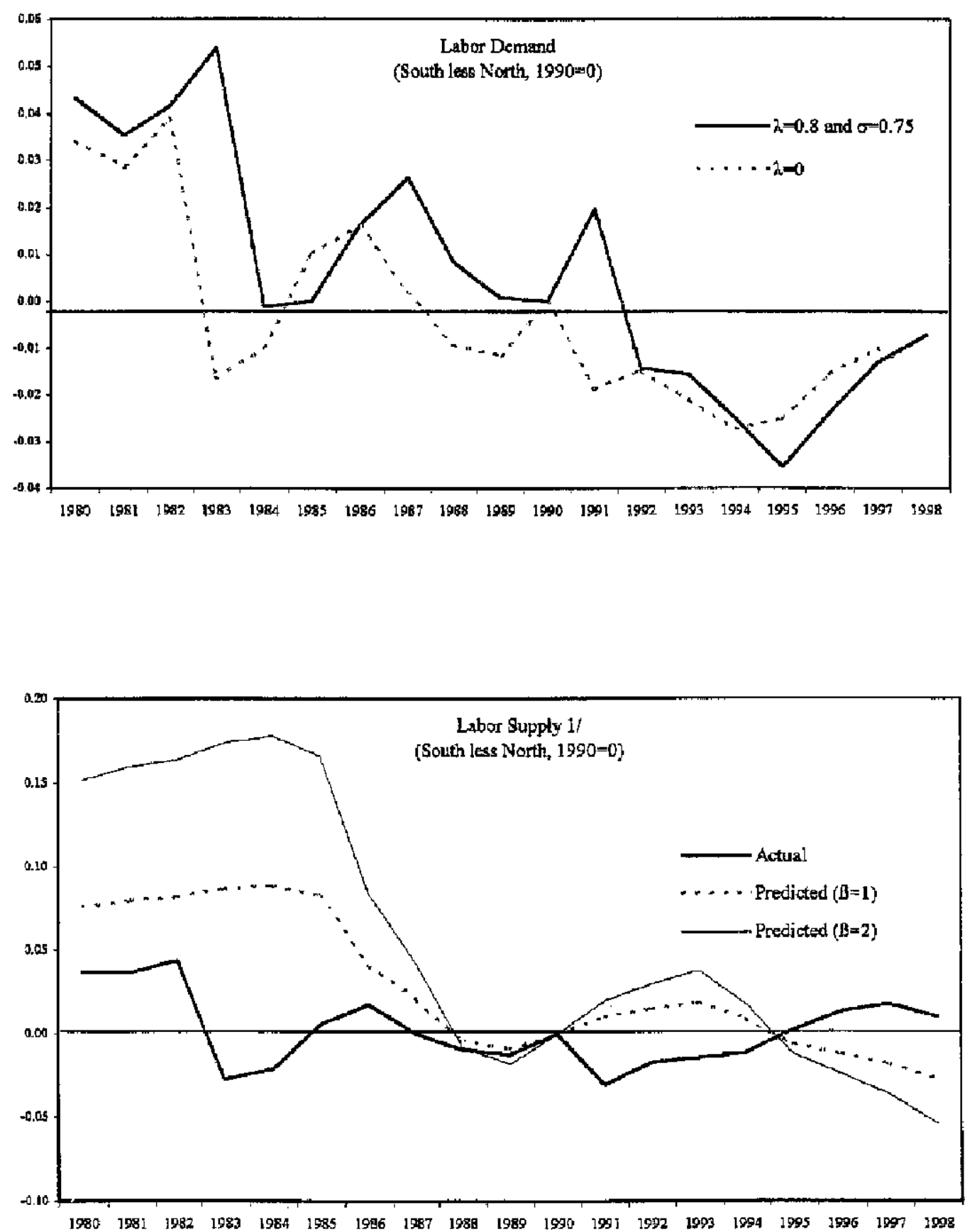

Sources: ISTAT; SVMEZ; and Fund staff calculations.

1/ Productivity-adjusted real wage at a constant unemployment rate. 


\section{Data APPENDIX}

\section{National data}

54. The source for the construction of national structural labor supply and demand variables is the OECD Economic Outlook database (2000) unless otherwise noted. The variables are computed for 1975-98 to allow construction of five-year moving averages where necessary.

55. Several variables deserve further explanation, including effective wages, total factor procuctivity, and the labor income share.

56. Effective wages are given by $\omega=\log (w / a)$. The real wage $w$ is computed as follows: $\mathrm{w}=$ WSSE/PGDPB, where WSSE denotes the yearly compensation rate in national currency in the business sector, and PGDPB the deflator for business sector GDP (OECD Analytical Database, 1999). The OECD obtains WSSE by dividing compensation of employees by dependent employment in the business sector.

57. Note that using the business GDP deflator, as required for the analysis, rather than the total GDP deflator is important for the results. One reason is that by comparison to the other countries, Italy experienced very high government consumption inflation-which basically reflects public wages - and thus higher total GDP inflation than business GDP inflation. This is clarified in the table, which also shows the GDP deflator constructed upon excluding from nominal (GDP) and real (GDPV) GDP, respectively, nominal (CGAA) and real (CGV) government consumption. Note that for the United Kingdom, no data have been available for the business GDP deflator before 1987 and for 1997-98; for the Netherlands for 1997-98; and for France and Italy for 1998 . For these years, the total GDP deflator excluding government consumption, computed as explained above, is taken instead.

58. The index of labor-augmenting technological progress $a$ has been obtained as the Solow residual in the business sector scaled by the share of labor in business income $a^{32}$ That is, $A a=(\Delta \log ($ GDPBV $)-\alpha \log (E T B)-(1-\alpha) \Delta \log (\mathrm{KBV})) / \alpha$, where GDPBV denotes real GDP $(y$ in the text), ETB employment ( $n$ in the text), and KBV the capital stock ( $k$ in the text), all in the business sector. Then $\Delta a$ is cumulated anmually (setting 1990=1) to obtain the index $a$.

\footnotetext{
${ }^{32}$ Note that this derivation of the Solow residual is only correct if $\mu=0$. Efficient bargaining reduces $\mu$ below 0 , while monopoly-selling power raises it above 0 . Deriving an estimate for $\mu$ lies beyond the scope for this paper. However, if the difference between $\mu$ and 0 is small (for example, less than 0.2), then the alternative approach to computing the Solow residual in Rotemberg and Woodford (1999, equation (3.2)) should yield similar results: a country that has grown faster by 1 percentage point annually over 20 years relative to another country but had the same annual 1 percentage point growth in its standard Solow residual would, at the end of the 20 years, have accumulated $3-4$ percentage points less growth in the Solow residual which adjusts for $\mu=0.2$.
} 
59. The labor income share is calculated as follows:

$\alpha=($ WSSE $*$ ETB $) /($ GDPBV*PGDPB*1000); and ETB is obtained as (ULCB*GDPBV*10)/WSSE, where ULCB stands for the unit labor costs in the business sector.

60. The labor force participation rates (L/P) is calculated as (LF/POPT), where LF stands for the labor force and POPI for the working age population. Detailed information on the OECD data series can be found in the Economic Outlook Database Inventory on the OECD's website (http://www oecd org/eco/out).

\section{Regional data}

61. The sources for regional accounts data are ISTAT (1980-1995/96) and SVIMEZ (1995/96-98). ISTAT has interrupted the production of regional accounts but SVIMEZ produces estimates, which are consistent with the ISTAT data. The series are constructed in the same way as for the national data.

62. One data series, however, is constructed from scratch, namely the capital stock for the Center-North and the South. The reason is that reliable data for regional capital stocks do not exist. To obtain regional capital stocks, it is assumed that both regions had identical capitaloutput ratios in 1980 , identical scrap rates throughout $1980-98$, and that their gross capital grew each year by the amount of regional investment in machinery, equipment, and means of transport. Data on national capital-output ratios and scrap rates come from the OECD databases; data on regional investment come from ISTAT/SVIMEZ. An analogous capital stock is computed for Italy to facilitate regional-to-national comparisons. Using the estimated capital stock data to compute the annual growth rate of $a$ for Italy over 1980-98 reveals a number of 2.11 percent, rather than the 1.47 percent obtained with actual OECD capital stock data (the total increase of calculated $a$ over the entire period 1980-98 in the Center-North exceeded that in the South by 6.1 percentage points, amounting to some 46.5 percent). Note that growth of $a$ under these calculations is considerably higher than with actual capital stock data, as investment in nonresidential property is not included in the regional capital stocks, for lack of data. However, for as long as this type of investment has evolved similarly across Italy, the omission does not raise serious concerns. A further point to bear in mind is that wages and employment refer to the business sector, while the data on investment in machinery and equipment are for the entire economy. Accordingly, they incluode investment by the nonmarketable services sector (general government and social institutions) which should be small.

63. Data on regional unemployment rates were provided by the Bank of Italy. 
Deflators, $1980-98$

\begin{tabular}{|c|c|c|c|c|}
\hline & Finland & Italy & Netherlands & $\begin{array}{r}\text { United } \\
\text { Kingdom }\end{array}$ \\
\hline \multicolumn{5}{|c|}{ (Annual percentage change) } \\
\hline \multicolumn{5}{|c|}{ Business GDP deflator 1/ } \\
\hline $1980-89$ & 7.0 & 11.1 & 2.8 & 7.4 \\
\hline $1990-98$ & 1.6 & 4.2 & 1.7 & 3.5 \\
\hline \multicolumn{5}{|c|}{ GDP deflator } \\
\hline $1980-89$ & 7.2 & 11.9 & 2.3 & 7.5 \\
\hline $1990-98$ & 1.9 & 4.8 & 2.0 & 3.8 \\
\hline \multicolumn{5}{|c|}{ Government consumption deflator } \\
\hline $1980-89$ & 7.2 & 13.3 & 0.5 & 8.9 \\
\hline 1990-98 & 2.3 & 6.7 & 2.4 & 3.9 \\
\hline \multicolumn{5}{|c|}{ GDP deflator, excluding government consumption } \\
\hline $1980-89$ & 7.2 & 11.6 & 3.0 & 7.1 \\
\hline $1990-98$ & 1.8 & 4.4 & 1.9 & 3.7 \\
\hline \multirow{2}{*}{\multicolumn{5}{|c|}{$\begin{array}{l}\text { Memorandum item: } \\
\text { Business GDP deflator, 1981-96 }\end{array}$}} \\
\hline & & & & \\
\hline OECD $1 /$ & 7.8 & & & \\
\hline ISTAT $2 /$ & 7.7 & & & \\
\hline
\end{tabular}

Sources: OECD Economic Outlook database; and Fund staff calculations.

1/ Source: OECD Analytical Database, 1999.

2/ ISTAT, ESA79 National Accounts. 


\section{RETERENCES}

Akerlof, G. A. and J.L. Yellen, 1990, "The Fair Wage-Effort Hypothesis and Unemployment," Quarterly Journal of Economics, Vol. 105, No. 2, pp. 255-283.

Altimari, N., R. Rinaldi, S. Siviero, and D. Terlizzese, 1997, "I Canali di Trasmissione della Politica Monetaria nel Modello Econometrico Trimestriale della Banca d'Italia," Temi di Discussione, No. 316 (Bank of Italy).

Argyle, M., 1987, The Psychology of Happiness (Methuen, London).

Bertola, G. and A. Ichino, 1995, "Crossing the River: A Comparative Perspective on Italian Employment Dynamics," Economic Policy, pp. $361-419$.

Blanchard, O., 1998, "Revisiting European Unemployment, Capital Accumulation, and Factor Prices," mimeo (Cambridge, Massachusetts: MT Press).

- _. -and Katz, 1997, "What We Know and Do Not Know About the Natural Rate of Unemployment," Journal of Economic Perspectives, Vol. 11, No.1, pp. 51-72.

Blanchard, O., and J. Wolfers, 2000, "The Role of Shocks and Institutions in the Rise of European Unemployment: The Aggregate Evidence," The Economic Journal, No. 110 , pp. C1-C33

Blanchflower, D. and A. Oswald, 1995, "International Wage Curves," in Freeman and Katz eds., Differences and Changes in Wage Structures, (Chicago, Illinois: University of Chicago Press).

—_. 1994, The Wage Curve (Cambridge, Massachusetts: MIT Press).

Bodo, G. and P. Sestito, 1991, Le vie dello sviluppo: dall'analisis del dualismo territoriale una propsta per il Mezzogionno (Bologna: Il Mulino).

Brandolini, A and P. Sestito, 1999, "Wage Dispersion, Low-Paid Workers and Household Poverty in Italy, 1977-95," mimeo, Bank of Italy.

Brandolini, A., R. Cappriello, and P. Casadio, 2000, "Job Creation and Destruction in Italy: Evidence from a Representative Sample of Manufacturing Firms, 1984-98," mimeo, Bank of Italy.

Brunello, G., C. Lupi, and P. Ordine, 1999, "Widening Differences in Italian Regional Unemployment," mimeo, University of Padua.

2000, "Regional Disparities and the Italian NAIRU," Oxford Economic Papers, Vol. 52 , pp. $146-177$. 
Brunetta, $\mathrm{R}$ and L. Tronti, 1994, Capitale umono e mezzogiomo: i nuovi termini della questione meridionale (Bologna: Il Mulino).

Bureau of Labor Statistics, International Comparisons of Manufacturing Productivity and Unit Labor Cost Trends, 1998. Available via Intemet: http://stats.bis.gov.

- International Comparisons of Hourly Compensation Costs for Production Workers in Manufacturing, 1998. Available via Internet: http:/stats.bls.gov.

Casadio, P. and L. D'Aurizio, 1999, "Per Capita Working Hours, Flexibility and Productive Efficiency in the Italian Manufacturing Sector between 1985 and 1998," mimeo, Bank of Italy.

Casavola, P., P. Cipollone, and P. Sestito, 1999, "Determinants of Pay in the Italian Labor Market: Jobs and Workers," in The Creation and Analysis of Employer-Employee Matched Data, ed. by D. Haltiwanger and others (New York: North Holland Elsevier).

Casavola, P., A. Gavosto, and P. Sestito, 1995, "Salari e mercato del lavoro locale," Lavoroe Relazioni Industriali, No. 4.

Daveri, F. and G. Tabellini, 1997, "Unemployment, Growth, and Taxation in Industrial Countries," CEPR Working Paper, No. 1681 (London).

Decressin, J., 1999, "Regional Income Distribution and Risk Sharing: How Does Italy Compare in Europe?" IMF Working Paper 99/123 (Washington: International Monetary Fund).

Del Monte, A. and A. Giannola, 1978, 11 Mezzogiorno nell'economia italianá (Bologna: I1 Mulino).

Erickson, C. and A. Ichino, 1995, "Wage Differentials in Italy" in Differences and Changes in Wage Structures, ed. by Freeman and Katz (Chicago, Illinois: University of Chicago Press).

European Commission, 2000, Italy's Slow Growth in the 1990s (Brussels: Directorate General Economic and Financial Affairs).

Faini, R., 1983, "Cumulative Processes of Deindustrialization in an Open Region: The Case of Southem Italy, 1951-73," Journal of Development Economics, Vol. 12, No. 3 , pp. 277-301.

Freeman, R. and L. Katz, 1995, Differences and Changes in Wage Structures (Chicago, Illinois: University of Chicago Press).

Gavosto, A. and F. Rossi, 1997, La disoccupazione italiana (Bologna: Il Mulino). 
Graziani, A., 1979, L'economia italiana del 1945 ad oggi (Bologna, Il Mulino).

Katz, L.F., 1986b, "Efficiency Wage Theories: A Partial Evaluation," in NBER Macroeconomics Anmal, 1986, ed. by S. Fischer (Cambridge, Massachusetts: MIT Press).

Layard, R., S. Nickell S, and R. Jackman, 1991, Unemployment (London: Oxford University Press).

Lindbeck, A, 1996, "The West European Unemployment Problem," Welwirtschaftiches Archiv, Vol. 132, pp. 609-37.

Lutz, M., 1963, Italy: A Study in Economic Development (London: Oxford University Press).

Marino, M. and R. Rinaldi, 2000, "Tassazione e Costo del Lavoro nei Paesi Industriali," mimeo, Bank of Italy.

Mortensen, D. and C. Pissarides, 1999, "Job Reallocation, Employment Fluctuations, and Unemployment," in Handbook of Macroeconomics, ed. by J. Taylor and M. Woodford (New York: North Holland Elsevier).

Murphy, K. and R. Topel, 1997, "Unemployment and Non-employment," American Economic Review, Vol. 87, pp. 295-300.

Nickell, S., 1997, "Unemployment and Labor Market Rigidities: Europe versus North America," Journal of Economic Perspectives, Vol. 11, No. 3, pp. 54-74.

Nicoletti, G., S. Scarpetta, and O. Boylaud, 1999, "Summary Indicators of Product Market Regulation with an Extension to Employment Protection Legislation," Economics Department Working Papers, No. 226 (Paris: OECD).

OECD, 2000a, Economic Survey: Spain, (Paris: OECD).

$\longrightarrow$, 2000b, Economic Survey: Italy, (Paris: OECD).

— 1999a, Taxing Wages $1998-99$ (Paris: OECD).

$\longrightarrow, 1999 \mathrm{~b}$, Surveillance of Tax Policies (Paris: OECD).

$\longrightarrow, 1999 \mathrm{c}$, Employment Outlook (Paris: OECD).

$\longrightarrow, 1999 \mathrm{~d}$, Benefit Systems and Work Incentives (Paris: OECD).

- 1998, Education Indicators at a Glance (Paris: OECD).

Oxford Econorric Forecasting, 1996, The New Oxford World Model: An Overview 
Pissarides, 1997, "The Impact of Employment Tax Cuts on Unemployment and Wages: The Role of Unemployment Benefits and Tax Structure," CEP Discussion Paper, No. 361 (London: London School of Economics)

—, 1990, Equilibrium Unemployment Theory, (Oxford: Basil Blackwell).

Romer, D., 1996, Advanced Macroeconomics (New York: MeGraw-Hill).

Rotemberg and Woodford, 1999, "The Cyclical Behavior of Prices and Costs," in Hondbook of Macroeconomics, ed. by J. Taylor and M. Woodford (New York: North Holland Elsevier).

Schinasi, G. and M. Lutz, 1991, "Fiscal Impulse," IMF Working Paper 91/91 (Washington: International Monetary Fund).

Shapiro, C. and J.E. Stiglitz, "Equilibrium Unemployment as a Worker Discipline Device," American Economic Review, Vol. 74, No. 33, pp. 433-444.

Triglia, 1992, Sviluppo Senza Autonomia (Bologna: Il Mulino).

Tullio, G. and S. Quarella, 1998, "Economic Convergence of Italian Regions: The Role of Organized Crime and Public Expenditures, 1960-93," mimeo, University of Brescia.

van Lomwel, G., 2000, Part-time Work in General Equilibrium, mimeo, Georgetown University.

Watson, C., B. Bakker, J. Martijn, and I. Halikias, 1999, "The Netherlands: Transforming a Market Economy," Occasional Paper No. 181 (Washington: International Monetary Fund). 


\section{ITAlY's Ftscal Strategy IN a MEdim-Term Framework ${ }^{33}$}

64. Over the course of the $1990 \mathrm{~s}$, Italy has undergone a remarkable fiscal adjustment, which enabled it to become one of the founding members of European Economic and Monetary Union (EMU). The deficit of the consolidated general government, which in 1990 stood at 11 percent of GDP (equal to its average over 1981-90), had been biought below 3 percent of GDP by 1997 , the year when compliance with the Maastricht limits was formally assessed. Over the following two years the deficit declined further, to less than 2 percent of GDP in 1999. The fiscal consolidation has also allowed Italy to arrest the explosive upward trend in its debt-to-GDP ratio, which peaked in 1994 at 124 percent, and has since been reduced by 9 percentage points.

65. This remarkable fiscal adjustment has set the stage for shifting the focus away from immediate considerations and toward a comprehensive medium-term fiscal strategy. What is the appropriate fiscal position over the medium term? How quickdy should the debt-to-GDP ratio be lowered further? Should the size of government-as measured by the ratio of public revenues and expenditures to GDP-be reduced? What would be the implications for the rate of growth of economic activity?

66. In view of Italy's still high stock of public debt, and of the potentially sizable budgetary impact of the looming demographic shock, the appropriate medium-term fiscal strategy should be designed with an eye to longer-term developments. This chapter tries to highlight some key tradeoffs and constraints that emerge in designing a fiscal strategy for Italy over the medium and longer term.

\section{A. The Budgetary Costs of Aging}

67. Italy enters the new decade with two constraints that are, in important respects, more severe than in most industrial countries. First, the debt stock is still above 110 percent of GDP, leaving the budget exposed over the medium term to the risk of increases in interest rates-the improvement in the fiscal balance of the last few years owes much to a substantial decline in interest payments. Second, Italy faces one of the most adverse aging trends among OECD economies-the old-age dependency ratio is projected to jncrease from less than 30 percent in 2000 to 67 percent by $2050^{34}$ (the highest in the OECD)-with sizable budgetary implications. This section reviews the fiscal pressures that are likely to arise from the projected aging of the Italian population.

\footnotetext{
${ }_{33}$ Prepared by Marco Annunziata.

${ }^{34}$ Based on World Bank demographic projections. The old-age dependency ratio is defined as the ratio of the population aged 65 years and older to the population of working age (20-64).
} 
68. The budgetary impact of population aging is likely to be most pronounced on social spending. At present, Italy's overall level of social expenditures is not grossly out of line with that prevailing in other industrial countries, but its composition is heavily biased toward pension benefits. Overall social expenditures as a ratio to GDP are about 2 percentage points higher than the OECD average (although slightly lower than the European Union average). Within social expenditures, however, health expenditures are among the lowest in OECD economies, while pension expenditures, on the other hand, are the highest. ${ }^{35}$ An important reason behind the high level of pension outlays in ltaly is the significant role played by benefits which are not strictly old-age-related: early retirement schemes and disability pensions, for example, have often been used as social buffers.

\section{Pensions}

69. The most direct impact of population aging will of course be felt on the evolution of pension benefits. Italy's pension system, which at the beginning of the 1990 s was one of the most generous among OECD countries, underwent three major rounds of reforms over the last decade. ${ }^{36}$ These reforms have gone a long way toward limiting the projected future increase in the ratio of pension expenditures to GDP: the authorities estimate that, in the absence of such reforms, they would have reached a staggering 23 percent of GDP by 2035 , when the budgetary impact of the aging crisis will reach its peak - that is, nearly 9 percentage points of GDP above their current level. These reforms notwithstanding, pension expenditures are bound to increase over the next few decades starting from an already very high level.

70. Estimates of the likely increase in pension outlays vary significantly. Projections developed by the Italian Treasury point to an increase in the pension expenditure to GDP ratio by $1 \frac{1 / 2}{2}$ percent of GDP over the next thirty years. The OECD (2000) regards the Treasury's forecast as perhaps optimistic, as the underlying demographic projections elaborated by ISTAT seem likely to overestimate fertility rates and underestimate longevity. The Fund staff, in a background study to last year's consultation (SM/99/115, 5/20/99), estimated that pension expenditures as a ratio to GDP could increase by some 4 percentage points between 2000 and 2035 .

71. Long-term projections of pension expenditures are unavoidably subject to a high degree of uncertainty, and they are particularly sensitive to assumptions on demographic variables (fertility and mortality), on labor market variables (unemployment, migration, and labor force participation rates), and on other key variables such as labor productivity rates. The staff's simulations were carried out making use of the projection model developed by the

${ }^{35}$ In 1994, pension expenditures in Italy were 2 percent of GDP higher than in France and Sweden, and some 3 percent of GDP higher than in Germany. See World Bank (1994).

${ }^{36}$ See Chapter I of SM/99/115, 5/20/99, and references therein. 
Italian Treasury, and were based on the central ISTAT projections for demographic and labor market variables. In the baseline scenario, the staff assumed that labor productivity would grow at 1.2 percent per year-the same rate employed, for example, by the U.S. administration to study the implications of aging for the U. S. social security system. This rate was suggested by a catch-up model of labor productivity growth, indicating a tendency for labor productivity rates in Italy and other industrial countries to converge to the U. S. rates as the gap in labor productivity levels is eliminated. The staff's study also considered two altemative scenarios: a "high productivity growth" scenario, with labor productivity assumed to grow at 1.7 percent per year, and a "low productivity growth" scenario, with labor productivity assumed to grow at 0.7 percent per year. The OECD's Ad Hoc Experts Group on Public Finance Implications of Aging has recently decided to assume in its baseline scenario a labor productivity growth rate of $1^{3 / 4}$ percent per year for all EU countries. In the staff's simulations of the high productivity growth scenario this would still result in an increase in pension expenditures by 3 percent of GDP between 2000 and 2035 .

\section{Health care}

72. The second important source of aging-related budgetary pressures is medical care for the elderly, which has so far played only a secondary role in Italy's social safety net. This is in part a reflection of the heavy bias of Italian social spending toward pension benefits-as mentioned above, health care expenditures in Italy are among the lowest for OECD economies, whereas pension expenditures are among the highest. It also reflects the Italian social context, where care for the elderly has traditionally been provided mainly within the family.

73. The social context, however, is likely to undergo important changes in the future. In particular, the combination of lower fertility rates-which lead to a decline in the average family size-and higher rates of labor force participation by women will make it increasingly difficult for the family to continue as the chief provider of care for the elderly. Pressures will therefore inevitably arise for the public sector to play an increasing role in the supply of care services for the elderly. At the same time, the demand for such services is likely to accelerate-even in the absence of significant changes to the social context per capita medical costs would increase with population aging, as the elderly are more likely to need recourse to pharmaceuticals or hospital care. Moreover, the proportion of the very elderly is projected to increase substantially - between 2000 and 2050 the proportion of people aged 80 years and over in the total population is expected to rise from 3.7 percent to 11.7 percert, bringing their share in the 65 and over age group from 23 to 37 percent. $^{37}$

74. The budgetary implications may be substantial, and the exact impact on public expenditure will of course depend on the policy decision with respect to service levels. A

${ }^{37} \mathrm{OECD}(2000)$. 
study published by the Italian Treasury considered two different scenarios. ${ }^{38}$ In the first scenario, standardized per capita consumption of health care services is assumed to increase at the same rate as labor productivity. ${ }^{39}$ Under the baseline demographic projections (ISTAT) population aging would then cause an increase in health care expenditures by 1.7 percent of GDP between 1995 and 2045. In the second scenario, standardized per capita consumption of health care services is assumed to increase at the same rate as per capita income. As in a context of aging population per capita income would grow at a slower pace than labor productivity, the increase in health care expenditure would be limited to 1 percent of GDP. Simulations developed by the OECD -based on different demographic assumptions than those of the Italian authorities--indicate that health care expenditures may increase by $1 \frac{1}{2}$ $2 \frac{1}{2}$ percent of GDP between 2000 and 2030 .

75. The burden of the increased cost of health care services for the elderly could be limited by shifting a part to the elderly themselves through higher co-payments. The OECD estinates that the retirement age population in Italy has incomes in the range of 90-100 percent of average incomes, and that many households are likely to have built up assets prior to retirement. This picture may however change significantly as a higher proportion of the retired population will be accounted for by those who retire under the new, less generous pension regime. Moreover, special care should be taken to safeguard the needs of the retirement-age households with incomes close to the poverty line.

76. Overall, therefore, increased demand for health care services stemming from population aging seems bound to impose significant additional pressure on the budget over the coming decades, compounding the pressure created by rising pension expenditures.

\section{B. Economic Growth and the Size of Government}

77. The refative ease or difficulty with which the additional budgetary pressures generated by population aging can be accommodated will depend to an important extent on the rate of economic growth. Population aging itself will of course tend to depress the rate of real GDP growth through a decline in the overall level of employment. ${ }^{40}$ This direct effect could be partially offset by a combination of (i) a decline in the uneraployment rate; (ii) an increase in the overall participation rate for women; (iii) an increase in the participation rate for both men

\footnotetext{
${ }^{38}$ Italian Treasury (1997).
}

${ }^{39}$ Standardized per capita consumption is defined as the per capita consumption of health care services that would prevail keeping unchanged the gender and age structure of the population as well as the type of health services provided.

40 This would occur both because of the increase in the proportion of the population older than the statutory retirement age, and because of the lower participation rates prevailing in the older (but still below the retirement age) age brackets. 
and women in the older age brackets, through an increase in the average effective retirement age; and (iv) an increase in immigration. For these developments to materialize, however, further significant structural reforms would have to be implemented, in particular in the labor market.

78. The productive potential of the economy may also benefit from reducing the size of government, and in particular from lowering the fiscal burden. The relationship between taxes and economic growth has been the subject of intensive investigation. Economic theory points to several ways in which higher taxes can depress output growth. ${ }^{41}$ Higher taxes can reduce the supply of production factors, discouraging investment or labor participation; they can lower the factors' marginal productivity, by distorting the intersectoral allocation of investment and employment; and they can limit productivity growth by discouraging investment in research and development or the development of high-tech industries.

79. The potential impact on productivity growth also points to the possibility that tax policy may have a long-run impact on economic growth rates. Such a possibility does not arise in the context of the traditional neoclassical growth framework à la Solow. In the Solow growth model, the steady state rate of per capita real GDP growth is uniquely determined by the exogenous rate of productivity growth; the distortionary impact of taxes therefore has a permanent impact on the level of output, but only a temporary impact on the growth rate of real GDP. In endogenous growth models, instead, the long run rate of economic growth is determined by economic decisions such as the accumulation of human capital or investment in research and development, and can therefore be affected by tax policy. Empirical studies based on endogenous growth theory provide some evidence that tax policy may have a permanent effect on the rate of economic growth, although the estimates of the impact vary significantly. ${ }^{42}$ In the case of Italy, the weak growth performance of the past decade seems to be due in no small part to the marked increase in fiscal pressure over the period (see Chapter I).

80. The impact of tax policy on economic growth will crucially depend not just on the level of the tax burden itself, but also on its composition, which is key in determining the distortionary impact of the tax system. Income taxes, for example, create a stronger disincentive to save (and hence to invest) than consumption taxes. ${ }^{43}$ Daveri and Tabellini (1997) highlight the potential growth-reducing impact of labor taxes in the presence of a

\footnotetext{
${ }^{41}$ See, for example, Tanzi and Zee (1997), and Engen and Skinner (1996). Tanzi and Zee (1998) provide evidence of a strong negative impact of taxes (in particular income taxes) on household savings.
}

${ }^{42}$ See Engen and Skinner (1996) and the references cited therein.

${ }^{43}$ See the empirical work of Mendoza, Milesi-Ferretti, and Asea (1997). 
highly unionized labor market, and provide empirical evidence of a high negative correlation between tax rates on labor income and employment and growth in European countries.

81. It can of course be misleading to consider tax policy in isolation, as the impact of a given change in taxes on economic growth will depend on what changes are simultaneously affecting public expenditure and the overall public sector balance. As in the case of taxes, the composition of public expenditures plays a key role, as some categories of public spending are likely to have a positive impact on growth-for example, public spencing on education, and investment in communication and infrastructure. ${ }^{44}$

82. Several empirical studies have found a negative correlation between the size of government as measured by the ratio of public spending to GDP or by the aggregate tax burden-above a certain threshold level - and economic growth. The evidence is, however, not unequivocal. Easterly and Rebelo (1993), Barro and Lee (1994), Barro and Sala-i-Martin (1995), and Sala-i-Martin (1996) have found a negative correlation between growth and such variables as government consumption, government investment, government deficits, overall government expenditures, and taxes. Barro and Sala-i-Martin (1995), however, also found a significant positive impact on growth of public spending on education.

83. Estimates of the precise impact of changes in the size of government on the rate of growth vary. Engen and Skinner (1992) found that an increase in the tax revenue-to-GDP ratio by 2.5 percentage points would lower long-term output growth rates by 0.2 percentage points. In their cross-country studies Easterly and Rebelo (1993) estimate a coefficient of 0.24 for overall government expenditure, whereas both Barro and Lee (1994) and Sala-1-Martin (1996) estimate a coefficient of 0.2 for government consumption. In the case of France, Habermaier and Lenseigne (1998) estimated that a 1 percentage point increase in the revenue ratio would reduce the employment rate by $0.3-0.5$ percent. In their analysis-of the macroeconomic impact of rising age-related entitlement spending, they assumed a coefficient of $1 / 4$ on the employment rate, which in turn implied that a 1 percentage point increase in the revenue ratio would lower the level of real GDP by about 0.2 percent.

84. Some findings in the empirical literature suggest, therefore, that the impact of a reduction in the revenue ratio on real GDP growth may range between 0.1 percent and 0.5 percent. In the case of Italy, for the purposes of the simulations discussed below in Section $C$, this paper will adopt the relatively conservative assumption that a decrease in the revemue ratio by 1 percentage point leads to an increase in the real GDP level by 0.2 percentage points, phased over a five-year period. As mentioned above, some empirical

\footnotetext{
${ }^{44}$ See Tanzi and Zee (1997) for a review of the arguments and of the literature. Several studies also focus on the impact of income distribution on growth, through the redistribution role of fiscal policy - see for example Alesina and Rodrik (1994), Persson and Tabellini (1994), and Perotti (1992).
} 
evidence supports the hypothesis of a permanent impact of tax reform on the rate of growth of output-not just the output level-indicating that the growth benefit of reductions in fiscal pressure could be stronger than assumed in the simulations carried out below.

\section{Two Illustrative Fiscal Scenarios}

85. This section develops two scenarios that illustrate altemative fiscal strategies over the medium and longer term. Both scenarios span the period through 2045. The first scenario, which will be called a "baseline" scenario, is characterized by a moderate reduction in the revenue-to-GDP ratio in the coming years combined with cuts in primary expenditures, which ailow for a gradual reduction in the debt-to-GDP ratio. The second scenario, which will be called a "reform" scenario, is characterized by early ambitious reform measures on the expenditure side, which allow for a faster reduction in the debt stock combined with a more decisive reduction in the revenue ratio; the more decisive expenditure and tax cuts also are assumed to pay off in the form of a higher (transitional) rate of growth of real GDP than under the baseline scenario.

\section{Baseline scenario}

86. It should be noted at the outset that the baseline scenario is not a "current policies" scenario, as it incorporates the assumption of a further moderate intensification of reform effort. It outlines a strategy that entails a moderate reduction in the revenue ratio and in the debt-to-GDP ratio over the medium-term, broadly in line with Italy's Stability Program through 2003. On the expenditure side, some expenditure-reducing measures are assumed to be adopted in the education sector, to capitalize on the decline in the number of students, brought about by population aging.

\section{Macroeconomic assumption}

87. This scenario assumes that, after the current cyclical upturn has run its course, labor productivity remains at 1.2 percent per year-as assumed in the baseline pension projections scenario developed by the staff in last year's background studies. ${ }^{45}$ This is projected to result in average real GDP growth of 0.5 percent per year over $2006-45$, as population aging causes a declime in employmeit. Inflation, currently projected somewhat above 2 percent in 2000 , is assumed to decline to 1.5 percent by 2002 and remain constant thereafter. The real interest

${ }^{45}$ See Chapter I of SM/99/115, 5/20/99, for further details. 
rate, which is projected to increase to about $4 \frac{1}{2}$ percent by 2005 , is assumed to gradually decline thereafter and stabilize at $3 \frac{1 / 2}{\text { percent. }^{46}}$

88. As a result of population aging, pension and health expenditures are projected to increase markedly. Concerning pension outlays, the baseline scenario embodies the central projections in last year's background study, which entail an increase in pension outlays by some 4 percent of GDP between 2000 and 2035. As for health expenditures, they are assumed to increase by $2 \frac{1}{2}$ percent of GDP over the same period (along the lines discussed above).

\section{The fiscal strategy}

89. Table 1 summarizes the fiscal strategy under the baseline scenario. The primary surplus is maintained constant at its current level of about 5 percent of GDP until overall balance is reached in 2006. This path, which is broadly consistent with the authorities' medium-term strategy, ${ }^{47}$ corresponds to a gradual decline in the structural primary surplus from $61 / 2$ percent in 1999 to 5 percent in $2006 .^{48}$ Once overall balance is reached, the budget is kept in balance. On the revenue side, the baseline scenario assumes that the revenue-to-GDP ratio is allowed to decline gradually by 2 percentage points over a four-year period, from 46.9 percent in 1999 to 44.9 percent in 2003 , as envisaged under the authorities' medium-term strategy.

90. On the expenditure side, the decline in interest payments, which has facilitated the fiscal consolidation of recent years, continues, but at a much more moderate pace, as much of the benefits of EMU accession in terms of reduction of the risk premium have already been reaped. The path for the overall balance outlinect above allows interest payments to come down gradually from $6 \frac{1}{2}$ percent of GDP in 2000 to $41 / 2$ percent of GDP by 2010 , and to just over 2 percent of GDP by 2045. Capital expenditures would decline somewhat, from 4 percent of GDP in 2000 to $3 \frac{1}{2}$ percent of GDP by 2003 , as envisioned in the authorities' program.

91. By around 2010, the budgetary impact of population aging begins to be felt more decisively. Pension and health expenditures, which by 2010 are already higher by over 1 percent of GDP than in 2000 , are projected to increase by a further $2 \frac{t}{2}$ percent of GDP

\footnotetext{
${ }^{46}$ This is based on the assumption that real interest rates in Italy over the long run will be tied to the world interest rate, which has been estimated at around 3.5 percent since the early 1980s. For a discussion of the determinants of the world real interest rate see Ford and Laxton (1999).

${ }^{47}$ As outlined in Italy's Stability Program for 2000-03, which however envisages that approximate overall balance would be achieved by 2003 .

${ }^{48}$ As the output gap is projected to narrow from 3.1 percent in 1999 to 0.7 percent in 2003 and to be eliminated in 2005 .
} 
by 2020 , and by almost an additional 3 percent of GDP between 2020 and 2035 . This sharp increase in age-related entitlements, which quickly outpaces the yield of the endogenous decine in interest payments, poses a serious policy dilemma. Under this scenario, the stock of public debt is still some 80 percent of GDP in 2010 , thereby limiting the possibility of accommodating the increase in health and pension outlays through a relaxation in the fiscal position (see below) ${ }^{49}$ In this scenario, it is assumed that only a small fraction of this additional budgetary pressure is absorbed within the expenditure side itself, more precisely through a moderate reform of the education sector. The reduction in the number of students, which also ensues from population aging, should allow for a reduction in education expenditures (estimated to be about 1 percent of GDP between 2010 and 2035).

92. In order to maintain budget balance, therefore, revenues will need to increase in line with the portion of the rise in health and pension outlays that cannot be compensated by savings on interest and education expenditures. The required increase in the fiscal pressure would be sizable: by 2035 , the revenue-to-GDP ratio would be some $31 / 2$ percentage points above its 2005 level. Figure 1 shows the evolution of general government's expenditure, revenue, and overall balance over the period, and clearly highlights the sharp increase in the revenue-to-GDP ratio between 2005 and 2035 . It is important to note that this increase in the tax burden would take place as GDP growth slows down due to population aging-given the underlying decline in employment, the rise in the per capita tax burden on employed persons would be proportionately higher still than the increase in the revenue ratio.

\section{Higher deficit scenarios}

93. To what extent could the increase in revenues be limited by allowing the overall balance to deteriorate? The room for maneuver is circumscribed by the need-under the Stability and Growth Pact-to prevent the overall deficit from rising above 3 percent of GDP (including in case of a cyclical downturn) and to continue reducing the debt-to-GDP ratio at a satisfactory pace (until this ratio has fallen well below 60 percent). Figure 2 shows the time path of the debt-to-GDP ratio and the revenue ratio under different "constant deficit rules": Starting from 2006, the overalt balance is maintained at a constant level as in the baseline, but this constant level is alternatively a deficit of $1,1.5$, or 2 percent of GDP. The top panel of Figure 2 clearly shows that a deficit of 1.5 percent of GDP would already be deemed "excessive," as it would imply that the debt-to-GDP ratio would start rising again by around 2025, when the debt stock is still above 80 percent of GDP. The bottom panel of Figure 2, noreover, highlights an additional drawback of these alternatives: under any of these deficit ales, the eventual increase in the revenue ratio would be even higher than in the baseline. The reason is that maintaining a higher deficit over this long horizon would slow

\footnotetext{
${ }^{49}$ Under the Maastricht Treaty, a country's debt ratio should be "sufficiently diminishing and approaching the reference value at a satisfactory pace" as long as the ratio itself is higher than the reference value of 60 percent of GDP
} 
down debt reduction, and backfire in the form of higher interest payments, eventually requiring a rise in the revenue burden.

94. Moving to a higher deficit relatively early-by 2006 in the scenarios in Figure 2 -is clearly selfudefeating, as it would lead to an even slower decline in the debt ratio accompanied by an even higher increase in fiscal pressure. An altemative strategy would keep the budget in balance for a more extended period before the overall balance is allowed to deteriorate in response to the increase in expenditures. Given the constraints under the Stability and Growth Pact, however, a strategy of this kind would not be very effective in limiting the increase in the revenue ratio. ${ }^{50}$

\section{Reform scenario}

95. A second scenario outlines a significartly more ambitious reform strategy, entailing a faster reduction in both the stock of public debt and the fiscal pressure. This more ambitious strategy would yield more pronounced savings on interest payments; and, helped by a lower tax burden, a higher rate of real GDP growth. It requires, however, important expenditure measures-over and above those assumed in the baseine scenario-some of which would necessarily involve tackling key expenditure areas such as pensions, health, and public sector employment.

\section{Macroeconomic assumptions}

96. Real GDP growth is assumed to be the same as under the baseline scenario over the WEO projection horizon to 2003. Thereafter, economic growth is assumed to respond positively to the lower level of fiscal pressure compared to the baseline scenario. More precisely, it is assumed that a reduction in the revenue ratio by 1 percentage point compared to the baseline scenario would temporarily boost real GDP by 0.2 percentage points, with the effect phased gradually over a five-year period. This would result in an average annual real rate of growth of GDP that is 0.03 percentage points higher over 2006-2045 than under the baseline scenario. The assumptions for the real interest rate and the inflation rate are the same as in the baseline scenario. The underlying increase in pension and health outlays brought about by population aging is assumed to be the same as under the baseline scenario, but it is assumed to be partially offset by reform measures in both sectors (see below).

\section{The fiscal strategy}

97. The fiscal strategy underlying the reform scenario is summarized in Table 2, and the path for general government revenue, expenditure, and overall balance is shown in Figure 3 .

\footnotetext{
${ }^{\text {so }}$ For example, maintaining budget balance through 2015 and then allowing the overall balance to deteriorate up a maximum deficit of 1 percent of GDP would halt the decline in the debt ratio while limiting the increase in the revenue ratio by only $1 / 2$ percent of GDP.
} 
This scenario assumes that the structural primary surplus is maintained at the level projected for 2000 -that is, $61 / 4$ percent of GDP-throughout the present decade, leading to an overali surplus of $2 \frac{1}{2}$ percent of GDP by 2010 . The stronger fiscal position over the medium term allows for a faster decline in the stock of public debt, which would drop below 60 percent of GDP after 2010.

98. The faster decline in the debt ratio is mirrored in interest payments, which fall from $6 \frac{1}{2}$ percent of GDP in 2000 to $3 \frac{1}{2}$ percent of GDP in 2010 and to less than 2 percent of GDP in 2045. As in the baseline scenario, capital expenditures would decline somewhat, from 4 percent of GDP in 2000 to $3 \frac{1}{2}$ percent of GDP by 2003 , as envisioned in the authorities" program.

99. On the revenue side, over 2000-2003 the same strategy as under the baseline reform scenario is followed, with a reduction in the revenue ratio by 2 percent of GDP over the fouryear period. The reduction in the fiscal burden is, however, continued beyond 2003:

through 2010 , with priority being given to maintaining a sizable primary structural surplus, the reduction in the revenue ratio is limited to a further $3 / 4$ of 1 percent of GDP; after 2010 , once the debt-to-GDP ratio has been brought below 60 percent, the reduction in the fiscal burden is accelerated. By 2020, the revenue ratio is 5 percent of GDP lower than in 1999. This reduction in the revenue ratio should be brought about in a way that secures a structural improvement in the tax system, reducing its distortionary impact-in particular, given Italy's starting position, the focus should be on reducing the high tax burden on labor (see SM/88/00, $5 / 15 / 00)$.

100. As mentioned above, meeting the dual objective of a stronger fiscal position and a more decisive reduction in the fiscal burden requires up-front action on the expenditure side. It is therefore assumed that measures to contain expenditures are implemented at an early stage in key sectors, including pension and health care. ${ }^{11}$ Thanks to these reform measures, the increase in pension and health expenditures between 2000 and 2010 is limited to $3 / 4$ of 1 percent of GDP. Important cost-cutting measures are also assumed to be carried out in other sectors, with primary expenditures other than health and pensions declining by nearly 4 percent of GDP between 2000 and 2010 , compared to $1 \frac{1 / 4}{4}$ percent of GDP under the baseline scenario.

101. As under the baseline scenario, it is by 2010 that population aging begins to impose significant pressure on the budget, with pension and health outlays projected to increase by nearly 2 percent of GDP between 2010 and 2020 , and an additional $13 / 4$ percent of GDP between 2020 and 2035 . The cumulative increase is some $21 / 2$ percent of GDP less than under the baseline scenario, as up-front reform measures reduce the long-run costs of age-related

\footnotetext{
${ }^{51}$ Last year's Selected Issues paper (SM/99/115, 5/20/99) outlines key reform measures that could be implemented in the pension system.
} 
entitlements. Under the reform scenario, moreover, the economy is now characterized by a stronger initial fiscal position (an overall surplus of $2 \frac{1}{2}$ percent of GDP compared to budget balance under the baseline scenario), a lower stock of public debt ( 60 percent of GDP compared to 80 percent of GDP), and a lower level of public expenditures.

102. The more ambitious strategy would, therefore, have created sufficient room to accommodate the remaining budgetary pressure from age-related entitlements through a gradual weakening of the fiscal position. From a surplus of $2 \frac{1}{2}$ percent of GDP in 2010 , it is allowed to swing to a deficit of about 1 percent of GDP by 2035, when the aging crisis reaches its peak ${ }^{57}$ The stock of public debt would continue to decline through 2030 , when it reaches some 30 percent of GDP. Subsequently, it would rise by some 6 percent of GDP as the transitory aging shock is absorbed, before stabilizing at the end of the projection period.

\section{The impact of higher productivity growth}

103. Fiscal projections over such a long time frame tend to be especially sensitive to changes in the underlying assumptions. In particular, it is important to evaluate the sensitivity of the two scenarios to different real GDP growth assumptions. Figure 4 summarizes the behavior of the key fiscal variables under the assumption that labor productivity grows at an annual rate of $13 / 4$ percent, rather than 1.2 percent, resulting in average real GDP growth of 1 percent per year over 2006-45 (see Section II.A above for further details on the productivity assumptioni). The higher real GDP growth rate by itself eases the fiscal burden of population aging, in particular by limiting the increase in pension expenditures as a percent of GDP. Moreover, for a given real rate of interest, a higher real GDP growth rate allows for a faster decline in the debt-to-GDP ratio and, correspondingly, in interest payments.

104. Under the baseline scenario, assuming that the same fiscal strategy outlined above is maintained, the debt-to-GDP ratio would still be only marginally below 80 percent by 2010 . The increase in age-related entitlements, however, would be contained to $4 \frac{11 / 2}{2}$ percent between 2000 and 2035 . Together with the somewhat faster decline in interest payments, this would limit the rise in the revenue ratio necessary to maintain budget balance to $1 \frac{1}{2}$ percent of GDP between 2005 and 2035 .

105. Under the reform scenario, the dividenc from higher economic growth could be allocated to a more sizable reduction in fiscal pressure. Assuming, for example, that the path for the overall fiscal balance were the same as under the lower productivity growth

\footnotetext{
${ }^{32}$ The deficit would therefore always remain smaller than the limit ( $1 \frac{112}{2}$ percent of GDP) calculated by the European Commission as the level that would allow Italy to accommodate historically observed cyclical fluctuations without breaching the 3 percent of GDP Maastricht limit for the general government deficit.
} 
assumption, the revenue-to GDP ratio could be lowered by as much as $6 \frac{1}{2}$ percentage points compared to the 1999 level.

\section{Conclusions}

106. Under the baseline assumption for productivity growth a comparison between the reform and baseline policy scenarios underscores three key points. First, maintaining a stronger fiscal position over the medium term would later on allow to absorb the transitory shock of population aging through a temporary increase in the debt stock, rather than through a marked increase in fiscai pressure. Second, decisive and early reductions in primary expenditures, together with the lower interest payments stemming from a faster decline in the debt stock, would create the room for a steady decline in the fiscal burden, with a positive effect on the productive potential of the economy. Third, the reform strategy would reduce fiscal vulnerability more rapidly, notably as it relates to sustained increases in interest rates.

107. Figure 5 compares the paths of the debt-to-GDP ratio and the revenue ratio (as well as primary current expenditures as a percent of GDP) under the two scenarios. It should be noted that the effects of the required increase in the fiscal pressure under the baseline scenario would have to be borne by a shrinking working population-creating the risk that the disincentive effect of higher taxes would exacerbate the decline in the labor force brought about by population aging. A traditional tax smoothing argument would also lead to prefer the temporary increase in public debt under the reform scenario as a response to a temporary expenditure shock (see, e.g., Barro, 1979) -an option that is, under the baseline scenario, not viable within the constraints of the Stability and Growth Pact.

108. On the other hand, the pursuit of an ambitious reform strategy would not be costless and requites sizable reductions in primary expenditures. Some measures could be aimed at limiting the budgetary impact of population aging through reforms of the pension and health care system. In the case of pension reform, key measures that could be considered include shortening the transition to the new (Dini) regime, and increasing the effective retirement age. ${ }^{33}$ Issues periaining to the health care system are discussed in Chapter III.

109. Table 3 provides a more detailed picture of the expenditure compression required under the two scenarios over the first ten years of the projection period. For each scenario, the table first separates out the two expenditure categories that are most directly affected by

${ }^{33}$ Increasing the effective retirement age could be achieved in different ways, for example, through an increase in the statutory retirement age, through an accelerated and across-theboard tightening of the requirements for seniority pensions, through a decline in the number of disability pensions, and through a strengthening of disincentives to early retirement-including modifying the "transformation coefficient" used to compute the initial pension benefit at resirement. See SM/99/115, 5/20/99 for more details. 
population aging, pension and health. The remainder of primary current spending is then broken down into four major categories: education, wages and salaries, goods and services, and other. Since the table combines a functional classification with an economic classification, care must be taken to avoid double-counting. Outlays on wages and salaries, and goods and services, therefore, are defined to exclude education and health care. For each one of these expenditure categories, and under each scenario, the table provides the value in percent of GDP and the real percentage changes.

110. Although the reform scenario shows a slower increase in both pension and health care outlays, it would still require, relative to the baseline scenario, further compression in other expenditures. Under the reform scenario, primary current expenditures (other than on pensions and health care) would have to decline in real terms by $1 / 2$ of 1 percent per annum on average over $2000-05$, and remain broadly unchanged in real terms over the following five

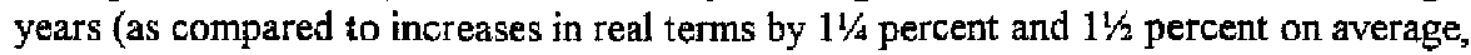
respectively, over the corresponding two five-year periods under the baseline scenario). 
Table 1. Italy: Fiscal Developments Under the Baseline Scenario

\begin{tabular}{lrrrrrrrrrr}
\hline & 1998 & 1999 & 2000 & 2003 & 2005 & 2010 & 2015 & 2025 & 2035 & 2045 \\
& & & & & & & & & & \\
\hline & 46.6 & 46.9 & 46.6 & 44.9 & 44.9 & 45.6 & 46.2 & 47.3 & 48.4 & 46.5 \\
Total revenues & 49.4 & 48.8 & 48.1 & 45.5 & 45.4 & 45.6 & 46.2 & 47.3 & 48.4 & 46.5 \\
Total expenditures & 8.1 & 6.8 & 6.6 & 5.5 & 5.3 & 4.5 & 3.6 & 3.0 & 2.6 & 2.2 \\
$\quad$ Interest payments & 41.3 & 42.0 & 41.5 & 40.0 & 40.1 & 41.1 & 42.6 & 44.3 & 45.9 & 44.4 \\
Primary expenditures & 3.8 & 3.9 & 4.0 & 3.5 & 3.5 & 3.5 & 3.5 & 3.5 & 3.5 & 3.5 \\
$\quad$ Capital expenditures & 37.5 & 38.0 & 37.5 & 36.5 & 36.6 & 37.6 & 39.1 & 40.8 & 42.4 & 40.9 \\
$\quad$ Primary current expenditures & 5.4 & 5.4 & 5.4 & 5.4 & 5.5 & 6.0 & 6.6 & 7.4 & 8.1 & 7.4 \\
$\quad$ Health & 14.2 & 14.3 & 14.4 & 14.4 & 14.5 & 15.2 & 16.2 & 17.5 & 18.6 & 17.5 \\
$\quad$ Pension & 17.9 & 18.3 & 17.8 & 16.7 & 16.7 & 16.5 & 16.2 & 15.9 & 15.6 & 15.9 \\
$\quad$ Nonhealth nonpension & & & & & & & & & & \\
& & & & & & & & & & \\
& -2.8 & -1.9 & -1.5 & -0.6 & -0.4 & 0.0 & 0.0 & 0.0 & 0.0 & 0.0 \\
Overali balance & 5.3 & 4.9 & 5.0 & 5.0 & 4.8 & 4.5 & 3.6 & 3.0 & 2.6 & 2.2 \\
Primary balance & & & & & & & & & & \\
& 116.3 & 114.9 & 110.7 & 99.6 & 94.1 & 80.8 & 71.7 & 58.7 & 50.4 & 42.4 \\
Publio debt & & & & & & & & & & \\
& & & & & & & &
\end{tabular}

Source: Fund Staff calculations. 
Table 2. Italy: Fiscal Developments Under the Reform Scenario

\begin{tabular}{|c|c|c|c|c|c|c|c|c|c|c|}
\hline & 1998 & 1999 & 2000 & 2003 & 2005 & 2010 & 2015 & 2025 & 2035 & 2045 \\
\hline Total revenues & 46.6 & 46.9 & 46.6 & 44.9 & 44.4 & 44.1 & 42.4 & 41.7 & 41.7 & 41.7 \\
\hline Total expenditures & 49.4 & 48.8 & 48.1 & 44.5 & 43.3 & 41.6 & 41.1 & 41.6 & 42.8 & 42.1 \\
\hline Interest payments & 8.1 & 6.8 & 6.6 & 5.5 & 5.1 & 3.7 & 2.3 & 1.6 & 1.6 & 1.8 \\
\hline Primary expenditures & 41.3 & 42.0 & 41.5 & 39.0 & 38.2 & 37.9 & 38.7 & 40.1 & 41.2 & 40.3 \\
\hline Capital expenditures & 3.8 & 3.9 & 4.0 & 3.5 & 3.5 & 3.5 & 3.5 & 3.5 & 3.5 & 3.5 \\
\hline Primary current expenditures & 37.5 & 38.0 & 37.5 & 35.5 & 34.7 & 34.4 & 35.2 & 36.5 & 37.7 & 36.8 \\
\hline Health & 5.4 & 5.4 & 5.4 & 5.3 & 5.3 & 5.8 & 6.4 & 7.0 & 7.6 & 7.2 \\
\hline Pension & 14.2 & 14.3 & 14.4 & 14.2 & 14.2 & 14.6 & 15.3 & 16.0 & 16.6 & 16.0 \\
\hline Nonhealth nompension & 17.9 & 18.3 & 17.8 & 16.0 & 15.2 & 13.9 & 13.5 & 13.5 & 13.5 & 13.5 \\
\hline Overall balance & -2.8 & -1.9 & -1.5 & 0.4 & 1.2 & 2.5 & 1.4 & 0.1 & -1.1 & -0.4 \\
\hline Primary balance & 5.3 & 4.9 & 5.1 & 5.9 & 6.3 & 6.3 & 3.7 & 1.6 & 0.5 & 1.4 \\
\hline Public debt & 116.3 & 114.9 & 110.7 & 98.2 & 88.8 & 53.8 & 45.7 & 31.1 & 31.7 & 35.2 \\
\hline
\end{tabular}

Source: Fund Staff calculations. 
Table 3. Italy: Frimary Current Expenditures Under the Two Scemarios

$200020012002 \quad 2003 \quad 200420052006 \quad 2007 \quad 2008 \quad 20092010 \quad \frac{\text { Averages }}{2001-05 \quad 006-10}$

Prodent Reform Scenario

Primary current expenditures

Health

Pension

Nonlezelth nonpension

Of which

Education

Wages and salaries if

Goods and services I/

Other
(In pereent of GDP)

$\begin{array}{rrrrrrrrrrrrr}37.5 & 36.8 & 36.6 & 36.5 & 36.5 & 36.6 & 36.7 & 36.8 & 37.0 & 37.3 & 37.6 & 36.6 & 37.1 \\ 3.4 & 3.4 & 5.4 & 5.4 & 3.4 & 5.5 & 5.5 & 5.6 & 5.7 & 5.8 & 6.0 & 5.4 & 5.7 \\ 14.4 & 14.4 & 14.4 & 14.4 & 14.4 & 14.5 & 14.5 & 14.6 & 14.7 & 14.9 & 15.2 & 14.4 & 14.8 \\ 17.8 & 17.0 & 16.9 & 16.7 & 16.7 & 16.7 & 16.7 & 16.6 & 16.6 & 16.6 & 16.5 & 16.8 & 16.5 \\ 0.0 & 0.0 & 0.0 & 0.0 & 0.0 & 0.0 & 0.0 & 0.0 & 0.0 & 0.0 & 0.0 & 0.0 & 0.0 \\ 4.7 & 4.7 & 4.7 & 4.7 & 4.7 & 4.7 & 4.6 & 4.6 & 4.6 & 4.5 & 4.5 & 4.7 & 4.5 \\ 6.1 & 6.1 & 6.1 & 6.1 & 6.1 & 6.1 & 6.1 & 6.1 & 6.1 & 6.1 & 6.1 & 6.1 & 6.1 \\ 3.7 & 3.4 & 3.4 & 3.4 & 3.4 & 3.4 & 3.4 & 3.4 & 3.4 & 3.4 & 3.4 & 3.4 & 3.4 \\ 3.3 & 2.8 & 2.7 & 2.5 & 2.5 & 2.5 & 2.5 & 2.5 & 2.5 & 2.5 & 2.5 & 2.6 & 2.5\end{array}$

(Real percentage change)

GDP

Primary current expenditures

Health

Pension

Nonhesith noupension

Of which

Education

Wages and salaries $1 /$

Goods and services J/

Other

$\begin{array}{rrrr}2.7 & 2.8 & 2.6 & 2.4 \\ 1.2 & 0.8 & 2.3 & 2.0 \\ 2.3 & 2.6 & 2.7 & 2.8 \\ 3.1 & 3.0 & 2.3 & 2.5 \\ -0.5 & -1.6 & 2.1 & 1.3 \\ 0.0 & 0.0 & 0.0 & 0.0 \\ 2.3 & 2.7 & 2.8 & 2.6 \\ 1.6 & 3.4 & 2.6 & 2.4 \\ 1.3 & -4.6 & 2.6 & 2.4 \\ -9.4 & -1.3 .5 & -1.1 & -5.1\end{array}$

2.4
2.5
3.0
2.4
2.4
0.0
2.2
2.4
2.4
2.4

2.
2.
3.
3.
2.
0.
1.
2.
2.
2

$\begin{array}{lll}2.2 & 2.0 & 1.8\end{array}$

$1.6 \quad 1.4$

1.2

2.5

$20-1.6$

$\begin{array}{llllll}3.0 & 3.2 & 3.3 & 3.4 & 3.5 & 3.7\end{array}$

$\begin{array}{llllll}3.0 & 2.4 & 2.4 & 2.5 & 2.9 & 2.9\end{array}$

$\begin{array}{llllll}2.1 & 1.9 & 1.7 & 1.4 & 1.1 & 0.9\end{array}$

$\begin{array}{llllll}0.0 & 0.0 & 0.0 & 0.0 & 0.0 & 0.0\end{array}$

$\begin{array}{llllll}1.9 & 1.6 & 1.4 & 0.9 & 0.3 & -0.1\end{array}$

$\begin{array}{llllll}2.2 & 2.0 & 1.8 & 1.6 & 1.4 & 1.2\end{array}$

$\begin{array}{llllll}2 & 2.0 & 1.8 & 1.6 & 14 & 1.2\end{array}$

(In percent of GDP)

Ambitious Reform Scenario

Primary currext expenditures

Health

Pension

Nonhealth nompension:

Of which

Education

Wages and salaries 1 t

Goopds and services $1 /$

Other

$\begin{array}{rrrrrrrrrrrrr}37.5 & 36.5 & 35.9 & 35.5 & 35.0 & 34.7 & 34.5 & 34.5 & \mathbf{3 4 . 5} & 34.4 & 34.4 & 35.5 & 34.5 \\ 3.4 & 5.3 & 5.3 & 5.3 & 5.3 & 5.3 & 5.4 & 5.5 & 5.6 & 5.7 & 5.8 & 5.3 & 5.6 \\ 14.4 & 14.2 & 14.2 & 14.2 & 14.1 & 14.1 & 14.2 & 14.2 & 14.3 & 14.4 & 14.6 & 14.1 & 14.3 \\ 17.8 & 17.0 & 16.4 & 16.0 & 15.6 & 15.2 & 15.0 & 14.9 & 14.6 & 14.4 & 13.9 & 16.1 & 14.6 \\ 0.0 & 0.0 & 0.0 & 0.0 & 0.0 & 0.0 & 0.0 & 0.0 & 0.0 & 0.0 & 0.0 & 0.0 & 0.0 \\ 4.7 & 4.6 & 4.5 & 4.4 & 4.2 & 4.1 & 3.8 & 3.6 & 3.5 & 3.3 & 3.2 & 4.3 & 3.5 \\ 6.0 & 6.0 & 5.9 & 5.8 & 5.8 & 5.8 & 5.8 & 5.8 & 5.8 & 5.8 & 5.8 & 5.8 & 5.8 \\ 3.7 & 3.4 & 3.4 & 3.4 & 3.4 & 3.4 & 3.4 & 3.4 & 3.4 & 3.4 & 3.4 & 3.4 & 3.4 \\ 3.3 & 3.0 & 2.6 & 2.4 & 2.2 & 1.9 & 2.0 & 2.0 & 1.9 & 1.8 & 1.5 & 2.5 & 1.8\end{array}$

(Real pereentige change)

$\begin{array}{rrrrrrrrrrrrr}2.7 & 2.8 & 2.6 & 2.4 & 2.4 & 2.3 & 2.1 & 3.9 & 1.7 & 1.5 & 1.3 & 2.5 & 1.7 \\ 1.3 & 0.1 & 0.9 & 1.3 & 1.0 & 1.3 & 1.7 & 1.8 & 1.6 & 1.3 & 1.1 & 0.9 & 1.5 \\ 2.0 & 2.1 & 2.2 & 2.4 & 2.6 & 2.7 & 2.9 & 3.2 & 3.8 & 3.8 & 3.9 & 2.4 & 3.5 \\ 3.1 & 1.5 & 2.5 & 2.5 & 1.7 & 2.7 & 2.3 & 2.2 & 2.2 & 2.3 & 2.8 & 2.2 & 2.3 \\ -0.4 & -1.6 & -0.9 & 0.0 & -0.2 & -0.4 & 0.7 & 0.9 & 0.2 & -0.5 & -1.7 & -0.5 & -0.1 \\ 0.0 & 0.0 & 0.0 & 0.0 & 0.0 & 0.0 & 0.0 & 0.0 & 0.0 & 0.0 & 0.0 & 0.0 & 0.0 \\ 2.3 & 0.5 & 0.6 & 0.3 & -2.4 & -0.6 & -3.5 & -3.9 & -2.0 & -3.0 & -3.6 & -0.3 & -3.2 \\ 1.6 & 1.7 & 0.9 & 0.7 & 2.4 & 2.3 & 2.1 & 1.9 & 1.7 & 1.5 & 1.3 & 1.6 & 1.7 \\ 1.3 & -.4 .6 & 2.6 & 2.4 & 2.4 & 2.3 & 2.1 & 1.9 & 1.7 & 1.5 & 1.3 & 1.0 & 1.7 \\ -8.8 & -7.1 & -10.5 & -5.5 & -6.1 & -10.9 & 2.6 & 5.4 & -2.9 & -5.3 & -13.2 & -8.0 & -2.7\end{array}$

Source: Fund Staff calculations.

1) Excluting health and thestion.

CInternational Monetary Fund. Not for Redistribution 
Figure 1. Italy: General Government Revenues, Expenditures, and Balance under the Baseline Scenario, 2000-2045 (In percent of GDP)

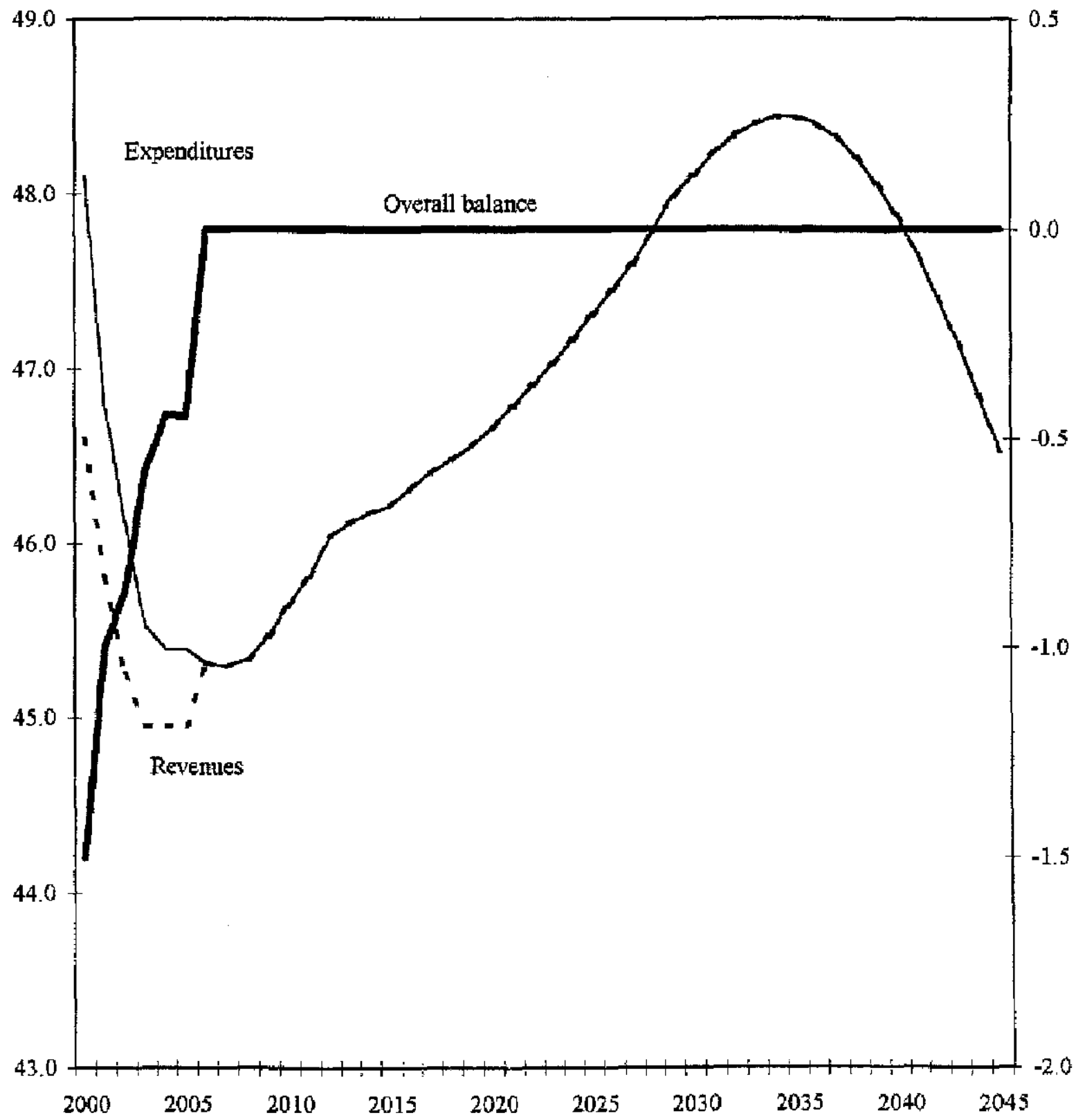

Source: Fund staff calculations. 
Figure 2. Italy: Debt and Revenue Dynamics under Different Deficit Rules in the Baseline Scenario, 2000-2045 (In percent of GDP)
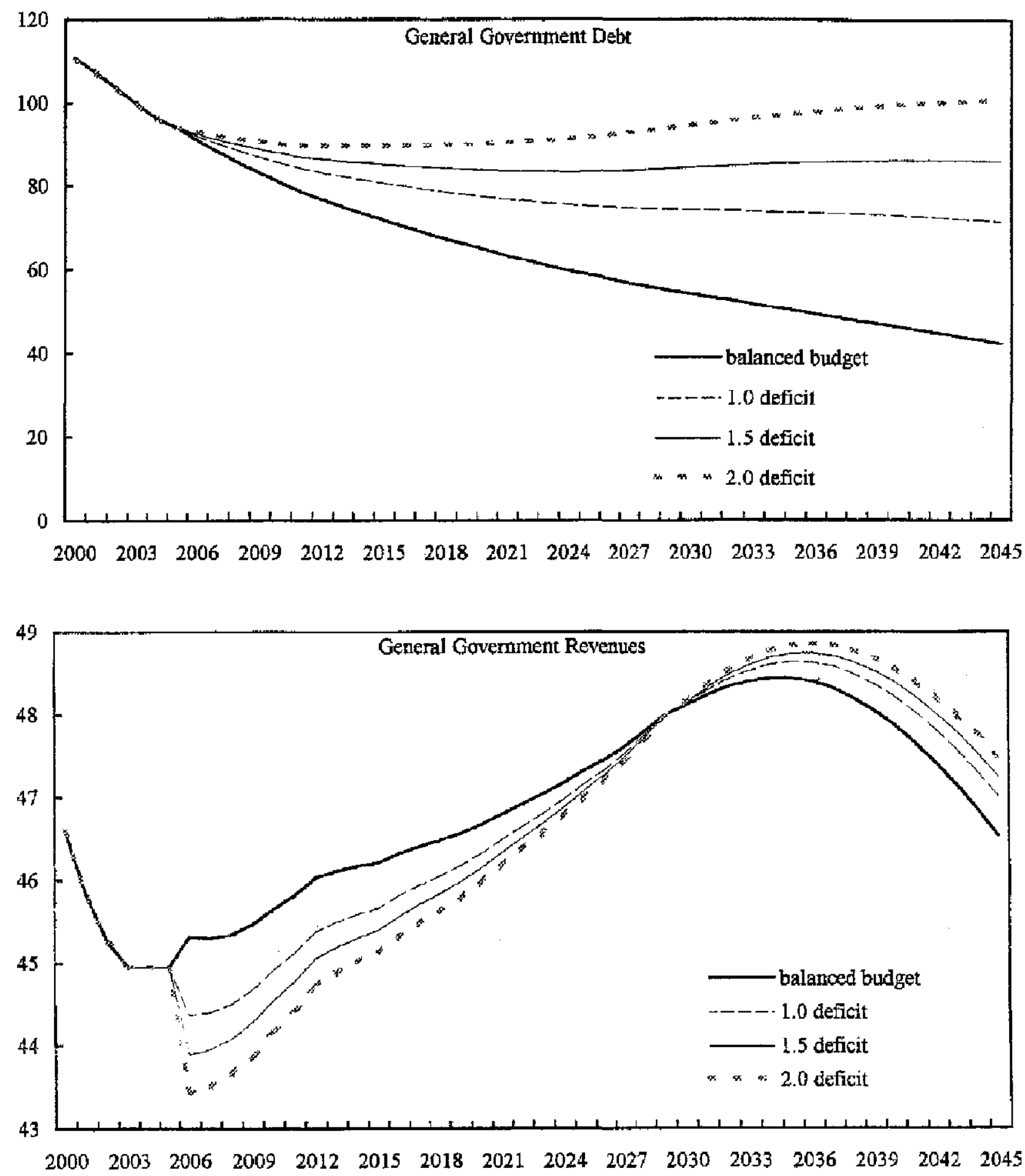

Source: Fund staff calculations. 
Figure 3. Italy: General Government Reventes, Expenditures, and Balance under the Reform Scenario, 2000-2045 (In percent of GDP)

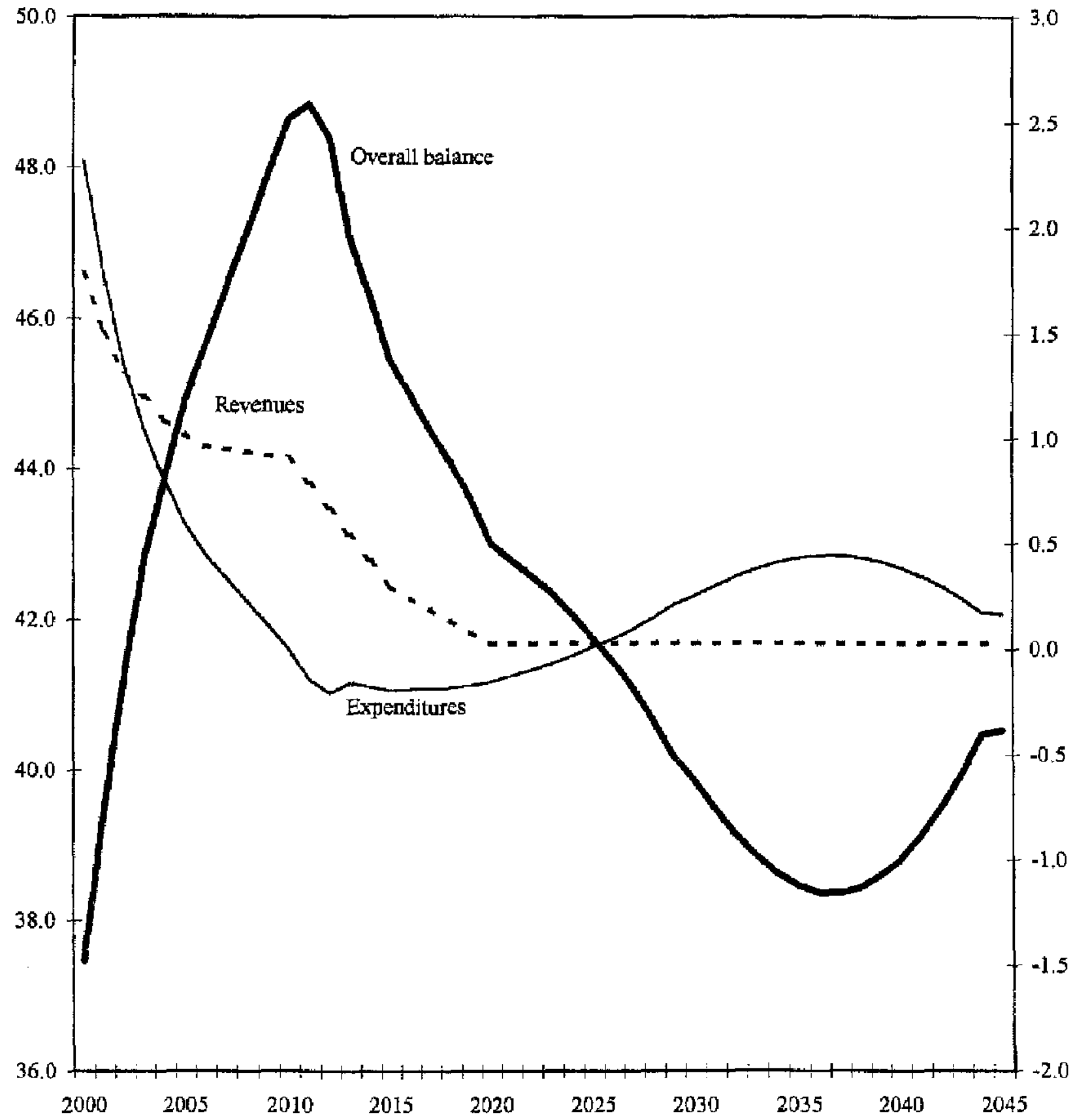

Source: Fund staff calculations. 
Figure 4, Italy: Revenues and Expenditures Under Different Scenarios and Productivity Growth Assumptions, 2000-2045
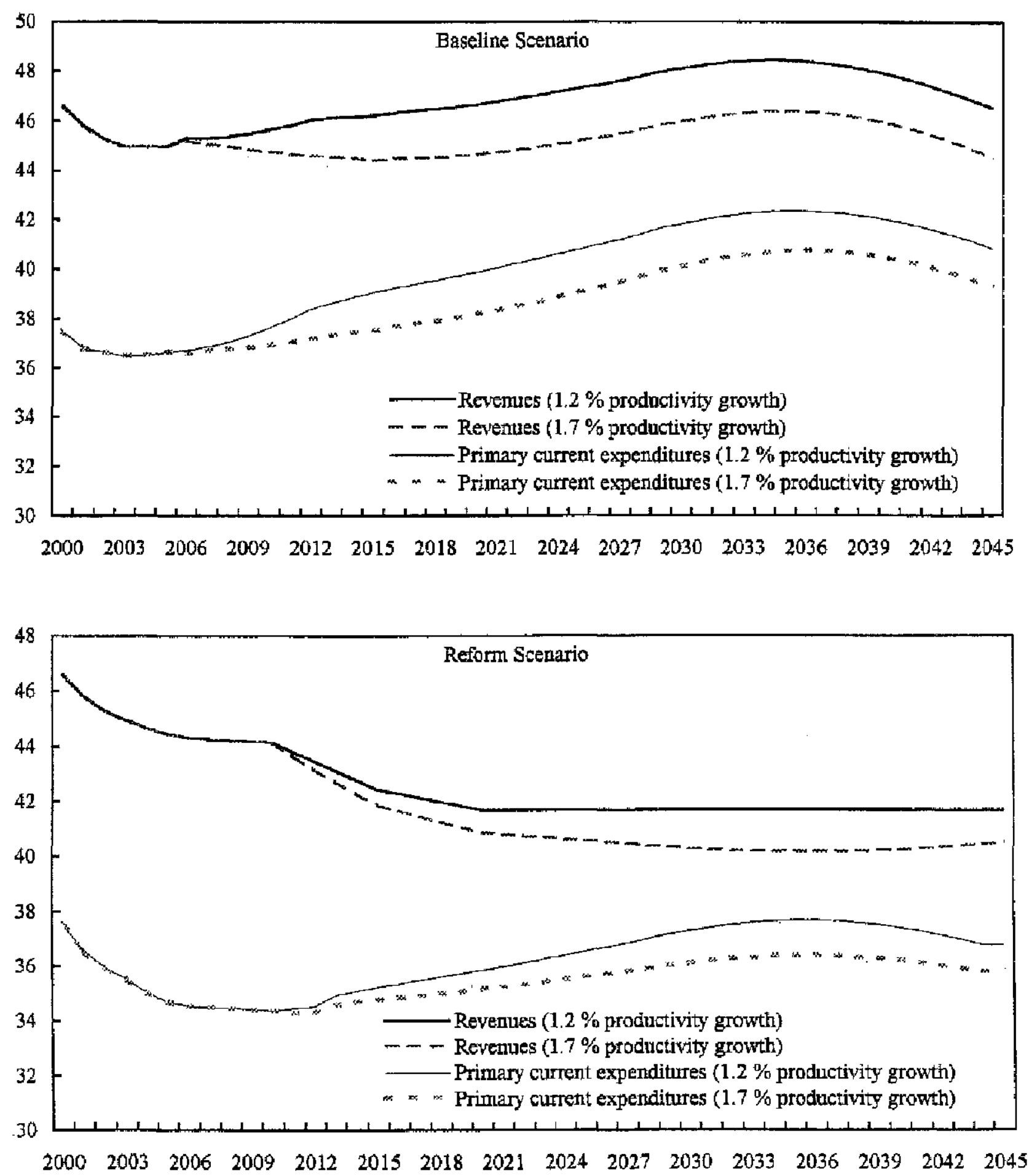

Source: Fund staff calculations. 
Figure 5. Italy: Public Debt, Revenues, and Primary Current Expenditures, 2000-2045

(In percent of GDP)
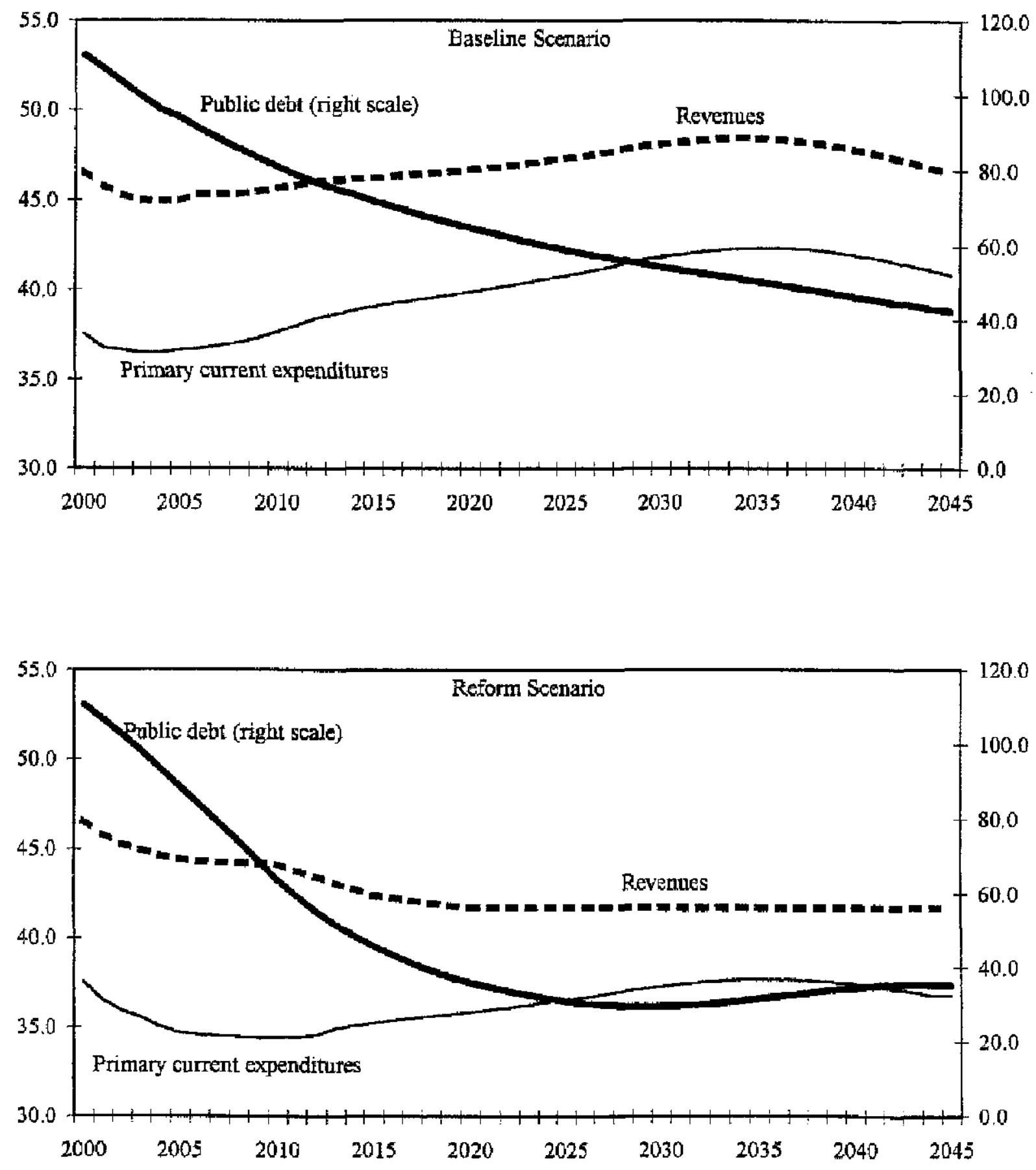

Source: Fund staff calculations. 


\section{REFERENCES}

Alesina, A. and D. Rodrik, 1994, "Distributive Politics and Economic Growth," Quarterly Journal of Economics, Vol. 109.

Barro, R., 1979, "On the Determination of the Public Debt," Jornal of Political Economy, Vol. 87.

and J. Lee, 1994, "Sources of Economic Growth," Carnegie-Rochester Conference Series on Public Policy.

Barro, R. and X. Sala-i-Martin, 1995, Economic Growth (New York: McGraw-Hill).

Daveri, F. and G. Tabellini, 1997, Unemployment, Growth and Taxation in Indtsstrial Countries.

Easterly, W. and S. Rebelo, 1993, "Fiscal Policy and Economic Growth: An Empirical Investigation," Journal of Monetary Economics: 32, pp. 417-458.

Engen, E. and J. Skinner, 1996, "Taxation and Economic Growth, NBER Working Paper No. 5826 (Cambridge, Massachusetts: National Bureau of Economic Research).

- 1992, "Fiscal Policy and Economic Growth, NBER Working Paper No. 4223 (Cambridge, Massachusetts: National Bureau of Economic Research).

Ford, R. and D. Laxton, 1999, "World Public Debt and Real Interest Rates, Oxford Review of Economic Policy: 15.

Habermeier, K., and F. Lenseigne, 1998, "French Public Finance: Modeling Long-Term Prospects and Reform Options," MMF Working Paper 98/12 (Washington: International Monetary Fund).

Italian Treasury, 1997, "Sanità, scuola e pensioni. Le nuove previsioni basate sugli scenari demografici ISTAT," Quaderno Monografico n. 13.

Mendoza, E., G. M. Milesi-Ferretti, and P. Asea, 1997, "On the Ineffectiveness of Tax Policy in Altering Long-Run Growth: Harberger's Superneutrality Conjecture," Journal of Public Economics: 66 (October).

OECD, 2000, 1999-2000 Annual Review-Italy (Paris).

Perotti, R, 1991, "Income Distribution, Politics, and Growth," American Economic Review, Papers and Proceedings, Vol. 82. 
Persson, T. and G. Tabellini, 1991, "Is Inequality Harmful for Growtb?" American Economic Review, Vol. 84.

Sala-i-Martin, X., 1996, "Transfers, Social Safety Nets, and Economic Growth, IMF Working Paper 96/40 (Washington: International Monetary Fund).

Tanzi, V., and H. Zee, 1998, "Taxation and the Household Saving Rate: Evidence from OECD Countries," IMF Working Paper 98/36 (Washington: International Monetary Fund).

_, 1997, "Fiscal Policy and Long-Run Growth, Staff Papers, International Monetary Fund, Vol. 44 (June).

World Bank, 1994, Averting the Old Age Crisis (Washington). 


\section{The Evolving Role of Regions In ITALy: The Financing aNd MaNa gement of Health CaRe Services ${ }^{54}$}

\section{A. Introduction}

11. The previous chapters argued that reducing the tax burden and improving public sector efficiency would have a central role to play in reinvigorating growth; and that these growth supporting fiscal policies called for reining in aging-related increases in public expenditure - a challenge far from unique, but particularly daunting for Italy in view of relatively adverse population aging trends. Following an assessment of the Italian pension system in last year's background studies (Chapter I in SM/99/115, 5/20/99), this chapter focuses on the second major expenditure area affected by population aging, health care.

112. Health care currently accounts for some 13 percent of general government primary expenditures in. Italy and could potentially increase by as much as $2 \frac{1}{2}$ percent of GDP as a result of the projected population aging. When the National Health Service (NHS) was established in 1978, the responsibility for providing public health care services was assigned to the regions; nonetheless, the NHS has in effect been centrally managed and financed. The recent reform of intergovernmental relations will bring about a major change in this regard, and increase the responsibility of regional governments in the managing, and their resources for financing, of the public health care system. This chapter focuses on the evolving role of regional governments, describes the recent reform of intergovernmental fiscal relations, and its implications for health care financing - assessing how these reform steps fit into the broader policy challenges outlined in the previous chapters. The discussion attempts to put Italy's experience in a broader cross-country perspective, by comparing the institutional setup and the expenditure trends to those prevailing in other industrialized countries.

113. The rest of the chapter is organized as follows. Section III.B gives a brief description of the regions in Italy and Section III. C describes their expenditure assignments. Section III.D concentrates on health care services, by far the most important expenditure assignment of the regions. Section III.E describes and assesses the tax assignment of regions and the future equalization mechanism. Section III,F gives a brief description of the rules limiting borrowing by regional governments, whose fiscal responsibilities are also covered by the Internal Stability Pact (Section III.G). Finally, Section III.H concludes.

\section{B. Key Characteristics of Italian Regions}

114. The principle of decentralization of powers was already established in Italy's Constitution of 1948 , which divided the Italian Republic into regions, provinces, and municipalities (Article 114). There are 20 regions (listed in Article 13!), 5 of which, namely Sicilia, Sardegna, Trentino Alto Adige, Frilli-Venezia Giulia, and Valle d'Aosta are special

\footnotetext{
${ }^{54}$ Prepared by Marco Annunziata and István Székely.
} 
statute regions, that is, regions that enjoy a higher degree of autonomy and whose statutes are approved with constitutional laws (Article 116). The remaining 15 are ordinary statute regions, and their statutes are approved with simple parliamentary laws.

\section{Geographic and demographic characteristics}

115. The 20 Italian regions form an extremely varied universe. They differ widely in size, ranging from the $25,000 \mathrm{sq} \mathrm{km}$ of Piemonte and Sicilia (each $81 / 2$ percent of the national territory) to the 3,000 sq km of Valle d'Aosta (1 percent of national territory). The population is also very unevenly distributed, with nearly 9 million people living in Lombardia ( $151 / 2$ percent of the total population) and less than $1 / 2$ of 1 million in Valle $d^{\prime}$ Aosta and Molise. Population density also varies considerably (see Table 1), and is on average 20 percent higher in the Center-North than in the South.

116. The regions also differ significantly in the age distribution of their population-an important determinant of future outlays on health benefits. The South is relatively "younger," with 15 percent of the population aged 65 and older compared to 19 percent in the CenterNorth (and to a nationwide average of $17 \%$ percent). Liguria is the "oldest" region, with onefourth of the population aged 65 and older, followed by Emilia-Romagna, Toscana, and Umbria with $21 \frac{1}{2}$ percent, whereas Campania is the "yourgest," with only 13 percent.

\section{Economic characteristics}

117. Recorded labor force participation rates are markedly higher for the Center-North (62 percent) than for the South (52 percent); Emilia-Romagna has the highest participation rate with 68 percent, whereas Puglia and Calabria are at the bottom, with participation rates barely above 50 percent, and Lazio is the only region in the Center-North with a participation rate below 60 percent (see Table 2). Perhaps the most dramatic difference between the Center-North and the South lies in the unemployment rate, which in 1999 averaged 22 percent for the South versus 7 percent for the Center-North.

118. Other economic disparities across regions are equally significant. The characterization of Italy as a "dual economy" can easily be understood by noting that 75 percent of Italy's GDP is produced in the Center-North (with Lombardia alone accounting for 20 percent) and only 25 percent in the South-this proportion has remained virtually unchanged over the last 20 years (Table 3 ).

119. Divergences in per capita GDP are equally stark. In 1996, when nationwide per capita income stood at Lit 32 million, four regions of the Center-North, that is, Valle d'Aosta, Lombardia, Trentino Alto Adige, and Emilia-Romagna, had a per capita income above Lit 40 million, while at the other end of the spectrum Calabria was the poorest region with just Lit 18 million, and Campania, Basilicata, and Sicilia were around Lit 20 million. Overall, the South had a per capita GDP of Lit 21 million, of only $2 / 3$ of the national average, whereas per capita income in the Center-North was 20 percent higher than the national average, at Lit 38 $1 / 2$ million (Table 4). 


\section{Expenditure Assignments of Regions}

\section{Expenditure responsibilities of regions}

\section{Historical perspective}

120. While the Constitution approved in 1948 already provided for the establishment of regions as autonomous entities and with directly elected regional governments, only special statute regions were quickly established. The first regional councils for ordinary statute regions were only elected in 1970, and two more years elapsed before the transfer of powers, personnel and funding necessary for these governments to operate took place. In 1977, the "616 decrees" transferred to the regions large portions of the state bureaucratic apparatus (with several thousands of employees being moved from the central administration to the regions), delegated to them legislative authority in important fields such as territorial planning and social agencies, and transferred to them almost full responsibility for provision of health care services. The regions thereby assumed responsibility for approximately one quarter of the national budget - in latge part as a consequence of the transfer of responsibility over the health care sector, which by 1989 already accounted for over one-half of regional spending. ${ }^{\text {ss }}$

121. The competencies and responsibilities of the ordinary statute regions are determined by Article 117; they include health services, social assistance, labor training and professional instruction, transports of regional importance, tourism, road maintenance and construction, public works, and agriculture. The areas of action of the special statute regions are broader and vary from case to case; in addition to those of the ordinary regions they often include partial responsibility for primary and secondary education, subsidies to industry, commerce and agriculture, and financial support for culture and the arts. The regions can in turn delegate some of their acministrative activities to the lower levels of governments, that is, provinces and municipalities (Article 118).

122. The regions are granted financial autonomy within the limits detemined by the national laws, which coordinate the regions' financial autonomy with that of the state, the provinces and the municipalities (Article 119). The regions are given (i) own revenues; and (ii) conditional and unconditional state transfers, in amounts sufficient for them to carry out their Jegular functions. Moreover, regions have their own patrimony. The state assigns by law special contributions to individual regions for specific purposes, in particular to foster development in the South and in the islands (Sicilia and Sardegna). Finally, regions are allowed to borrow to finance investment (see below).

\footnotetext{
${ }^{\text {ss }}$ Putnam (1993).
} 


\section{The Bassanini neform}

123. The recent reform of intergovernmental fiscal relations is part of an overall reform of the state in Italy, known as the Bassanini reform, ${ }^{56}$ comprising two framework laws, Laws 59 and 127 of 1997, and subsequent implementation decrees. The goal of the reform is to create a service-oriented state providing high quality services at the lowest cost (including compliance costs). The reform is to be carried out within the context of the existing constitution-though decentralization is a central part of the reform, the unitary nature of the Italian state will remain unchanged.

124. The basic idea behind the reform is to redefine the role of the state, divest noncore activities, and reallocate core activities across levels of govemment and different parts and agencies of the central government in order to achieve the above-stated goal. The reform involves decentralization of the retained functions of government, deregulation, simplification of administrative procedures, contracting out of government services, a new approach to human resource management, and a reform of the budget process.

125. Concerning decentralization, the first step has been to identify those functions that should stay with the central government. These include justice, national security, defense, international relations and trade, relations with international organizations and coordination of EU relations, macroeconomic policy, national energy policy, industry, telecommunication, transport, education, and research, as well as setting the national policy objectives and standards in areas such as agriculture, employment, public housing, public works, and consumer protection. The remaining core functions have been assigned to subnational governments according to the principle of subsidiarity. Trade and industrial development. policies have been devolved to the regions. The final step in the process of decentralization, which has been designed as a five-year process, will be the transfer of financial and human resources to the subnational governments. The modalities of the process will be agreed upon at the central state-tegions and the central state-municipalities conferences, established to foster cooperation between the different levels of government.

\section{Overall trends in public expenditure at the subnational level}

126. Expenditure responsibilities of subnational governments expanded substantially in the second half of the 1970s, when total expenditures of subnational governments came to account for about 10 percent of GDP, or roughly one-fourth of total expenditures of the general government (Figure 1). As the size of government expanded, so did the role played by subnational governments - within a few years their total expenditures increased to over 14 percent of GDP. Their share in total expenditures of the general government was close to

\footnotetext{
${ }^{56}$ For a detailed description of the Bassanini reform, see Presidenza Consiglio dei Ministri (2000). For an analytical assessment, see Pintus (2000).
} 
30 percent for much of the $1980 \mathrm{~s}$. As a percent of GDP, total expenditures of subnational governments declined over the following decade, from a peak of 15 percent in 1991 to about $13 \frac{1}{2}$ percent at the end of the 1990 s.

127. The decline in expenditures over the 1990 s reflected the contribution of subnational governments to Italy's fiscal consolidation effort in the run-up to stage three of EMU: the overall deficit of subnational governments dropped from an average of 1 percent of GDP over 1981-90 to an average of 0.2 percent of GDP over 1991-98 (as the deficit of the consolidated general government declined from an average of 11 percent of GDP to an average of 7 percent of GDP). In 1990, the general government deficit stood at 11 percent of GDP, and subnational governments recorded a deficit of 1.3 percent; by 1997 , the year when compliance with the criteria for EMU accession was assessed, the deficit of the general government had declined to 2.8 percent of GDP, and that of subnational governments to 0.3 percent (Figure 2)

128. The increase in total expenditures mentioned above was accompanied by a nearcoubling of revenues from $71 / 2$ percent of GDP in 1976 to $14 \% 2$ percent of GDP in $1991-92$ (see Table 5, which summarizes the consolidated budget of subnational governmentsregions, provinces, and municipalities-over the period 1976-98). Transfers from the state and other public institutions increased rapidly at the beginning of the period, from $41 / 2$ percent of GDP in 1976 to a peak of 10 percent in 1983; tax revenues increased steadily, from less than 1 percent of GDP in the late 1970 s-early 1980 s to $3-3 \frac{1}{2}$ percent of GDP in the mid-1990s, and then jumped to 51/2 percent of GDP in 1998 with the introduction of IRAP. On the expenditure side, wages and salaries quickly increased from $31 / 2$ percent of GDP in the late 1970 s to an average of $4 \frac{1}{2}$ percent of GDP over $1980-98$; social transfers, which accounted for only $1 / 3$ of 1 percent of GDP in the late 1970 s, increased to $2-21 / 2$ percent in the 1980 s and 1990 s; whereas capital expenditures, which between 1980 and 1991 had hovered at about 3 percent of GDP, thereafter declined to between 2 and $2 \frac{1}{2}$ percent for the remainder of the decade. The share of social transfers in total expenditures quickly increased from just 3 percent of total expenditures in the late 1970 s to about 15 percent on average over 1980-98 (Table 6).

129. Provision of health care services is currently by far the single most important function in the regions' budgets (Table 7). ${ }^{57}$ In 1999 , outlays on health care (both current and capital)

\footnotetext{
17 Besides those of the regions, the table also includes the accounts of the "autonomous" provinces of Trento and Bolzano, which share some of the responsibilities of regions, notably for the provision of health services.
} 
accounted for over 60 percent of regions' total cash expenditures. ${ }^{58}$ Almost the totality of the regions' expenditures on health care consist of transfers to local health units and hospitals.

\section{The Management and Financing of the Public Health Care System}

130. The Italian public health care system has been highly centralized and integrated-even though most of the responsibilities for providing health care services were assigned to the regions when the NHS was established in 1978. The central government (Ministry of Health) determined in detail the services all regions had to provide and the budget allocated earmarked resources based on the cost estimates of the Ministry of Health. The regions have enjoyed very little freedom in this respect, and consequently had very little incentive to contain costs. While this arrangement made the decentralization of the management of the NHS a notional one, it made it possible to maintain a highly uniform level of per capita expenditure across regions. This, however, did not ensure equal access to and quality of services, because the efficiency of local health units varied greatly across regions.

131. The system was also characterized by recurrent budgetary overruns on health outlays, often financed through accumulation of arrears to suppliers. The regions have argued that (i) expenditure overnuns were the unavoidable consequence of unrealistic budget allocations set by the central government; and that (ii) given that health services were largely mandated by the state, they had little or no control over the evolution of health expenditures. The constitutional court agreed on the latter point, and a large part of the responsibility for repaying the outstanding arrears has been borne by the central government. More recently, the central govemment and the regions have jointly agreed on what they consider a more realistic budgetary allocation for health expenditures-a move that the government hopes will increase "ownership" on the part of the regional authorities, at the same time as a major reform of health care expenditure is underway.

132. Previous reforms of intergovernmental fiscal relations concerned almost exclusively the revenue assignments of the regions. The reform being presently carried out on the basis of the 1997 framework law completes this process. However, the reform includes a new element which could fundamentally change the way the NFS is managed: starting in 2004, the regions will be free to allocate their revenues and a new system of centralized monitoring of health care services delivered by the local health units will be set up. Regions failing to meet the defined minimum standards can be sanctioned; the transfer they get from the equalization fund can be reduced.

\footnotetext{
${ }^{38}$ Heaith expenditures consist for about 60 percent of purchases of goods and services, and for about 40 percent of payments of wages and salaries.
} 
133. Within a cross-country framework, the remaining part of this section gives a brief analysis of public health care expenditure and financing in Italy. A detailed analysis of micro efficiency or incentive structures, even at the national level, is beyond the scope of the paper. ${ }^{59}$

\section{Macroefficiency}

134. The share of total health care expenditure in GDP in Italy grew rapidly (Figure 3), and reached the EU average by 1990 (Figure 4). During the 1990s, however, public health care expenditures in Italy slowed down compared to the rest of the EU. Driven by the need for fiscal consolidation, current public health care expenditure was reduced in real terms between 1990 and 1995 (Figure 5); as a result, the share of public health care expenditure in GDP fell by 1.2 percentage points between 1991 and 1995. Part of this reduction was offset by a rapid increase in private health care expenditure, a clear indication that the reduction was not demand driven. ${ }^{60}$ Besides the Scandinavian countries, no other country within the EU managed to reduce the share of health care expenditure in GDP during this periodbetween 1990 and 1995, it increased by 0.9 percentage point in the rest of the $\mathrm{EU}$, and by 1.7 percentage points in Germany. This would suggest that Italy was rather successful in containing health care costs, in particular given the rapid increase in the elderly as a proportion of the population (Figure 6). In the 1990s, population aging was one of the most important factors explaining the continued increase in the share of health care expenditure within the EU (Figure 7), in spite of numerous attempts to arrest this tendency (OECD, 1994).

135. However, a part of the reduction in public health care expenditure achieved in the first half of the 1990s may not have been sustainable. The share of public health care expenditure in GDP started to increase after 1995, offsetting one-fourth of the reduction achieved earlier. This increase was partly related to weak growth and the continued increase in the share of the elderly population, but also to the way the reduction in health care expenditure was achieved and, as described below, the way health care costs were budgeted and financed. In 1996 and 1997, the overnuns in public health care expenditure were sizable, ${ }^{61}$ mostly financed by unpaid obligations to private suppliers. As Table 8 shows, wage costs accelerated rapidly after 1995 , clearly indicating that earlier wage cost reduction was not achieved in a sustainable

${ }^{59}$ For a general description of the Italian health care system, see OECD (1994).

${ }^{60}$ The different trends in public and private health care expenditure between 1980 and 1985 also suggest that in periods of radical cuts in public health care expenditure the demand for private health care increases, partly offsetting the decline in public expenditure. The rapid increase in private health care expenditure in the first half of the 1990 s reflected importantly an increase in co-payments.

${ }^{61}$ Actual expenditures were 4.7 and 7 percent higher, respectively, than assumed in the budget. 
manner; the same was true for contracted services and pharmaceuticals. The rapid increase in the arrears of the local health units and in expenditure ${ }^{62}$ on contracted health care services during this period were also very closely related developments, again indicating that the way the earlier reductions were achieved was not sustainable. The experience of 1995-97 suggests that it is not possible to achieve sustained reduction in public health care expenditure without properly designed reforms aimed at increasing efficiency.

\section{Microefficiency and regional pattern of public health care expenditure}

136. A detailed analysis of microefficiency at the regional level is well beyond the scope of this paper. A partial analysis commissioned by the technical expert group on public expenditure of the Ministry of Treasury (CTSP, 1999) suggests that relatively uniform levels of public health care expenditure did not result in uniform levels of health services provided by the local health care units (output), or the same improvement in health outcome across the regions.

137. During 1980-97 regionally financed health care expenditure increased by 2.5 percent per year in real terms, considerably faster than real GDP. Correcting for population growth, which was faster in the South, and aging, which was more pronounced in the North, average growth in real expenditure was below average in the regions in the North East and the Center (Table 9). This reflected a catch-up process, as the levels of per capita health care expenditure in the regions with lower average growth rates were still above the national average in 1997 (Table 10).

138. The extent of regionat inequality in public health care expenditure in Italy is limited, in particular when adjustment is made for differences in age structure and for the expenditure on hospital care for nonresident patients (Figure 8 and Table 10 ). ${ }^{63}$ At least as far as expenditure on health care (input) is concerned, the NHS did achieve its stated goal of providing uniform level of assistance (Law 833/78).

139. A noteworthy fact is the rapid increase in health care expenditure in the northern special statute regions in the $1990 \mathrm{~s}^{64}$ Income levels in these regions are close to that in

${ }^{62}$ Expenditure numbers for public health care costs are on an accrual basis, thus they include arrears to suppliers. The part of total expenditure, which was not financed by the budget, reached 2.7 and 8.8 percent in 1996 and 1997 , respectively.

${ }^{63}$ As the comparison of nonadjusted and adjusted relative per capita expenditures for the different regions show, regions in the South are net beneficiaries of hospital care provided to their residents in the northern-central regions. The total size of this expenditure is rather large.

${ }^{64}$ For a discussion of the role of the special statute regions, see Chapter II in SM/99/115, $5 / 20 / 99$. 
Lombardia (the richest ordinary statute region), and other characteristics are also similar to those of the rich northern regions. These regions, however, enjoy a much higher level of expenditure autonomy and have much larger tax bases because of their special tax sharing arrangements with the central government. There are pronounced differences in cost structures across regions (Table 11). The share of expenditure on services directly provided by the local health units is lower in the South than in the North, with regions in Central Italy closer to the regions in the South. Within the services directly provided by the local health units, the share of personnel costs in the South is significantly higher than in the North, reflecting a rapid growth of health personnel since the establishment of the NHS which resulted in low productivity, rather than increasing output. (Expenditure on pharmaceuticals is also significantly higher in the South than in the other regions, reflecting a higher per capita expenditure in the South partly explained by a higher share of exempt prescriptions. $)^{65}$

140. More than half of the increase in NHS staff between 1981 and 1997 was attributable to the regions in the South, one -third of which to Sicity, where the increase was over 40 percent ${ }^{66}$ compared to a national average of 14 percent. ${ }^{67}$ At the same time, local health units in the South relied on contracted private hospital care and specialist services to a much larger extent than in the North, and patients from the regions in the South accounted for around 90 percent of outward hospital mobility (hospitalization of patients in other regions) ${ }^{68}$ While Southern regions had the lowest ratio of hospital beds to inhabitants, they had also the lowest bed-occupancy ratios. Empirical research (see Alesina and others, 1999) found a significantly lower incidence of recourse to certain public health care services ${ }^{69}$ and

\footnotetext{
${ }^{65}$ Per capita expenditure on pharmaceuticals dispensed by pharmacies was 56 percent higher in Campania than in Lombardia. In 1995-97, expenditure on pharmaceutical increased rapidly. Though the rapid increase was common to all regions, the increase in the South was significantly higher (see Corte dei Conti, 1999).
}

${ }^{66}$ Overstaffing in public services is a widespread phenomenon in the South. Recent empirical research (see Alesina and others, 1999) suggests that excessive public employment in the South was an important mechanism through which budgetary resources have been channeled to the South and through which the government tried to reduce unemployment.

${ }^{67}$ It is worth mentioning that the rate of increase in NHS personnel in the special statute regions in the North was in fact higher than in the South, and at present these regions have the highest per capita levels of public health care employment in Italy.

${ }^{68}$ The outflow of hospital patients from Southem regions has increased steadily in recent years.

${ }^{69}$ Medical tests taken in public laboratories and medical examinations carried out in public health care facilities (see Table 4 in Alesina and others, 1999). 
significantly lower rating of the quality of health care services by residents in the South. ${ }^{70}$ Improvements in health outcome were also significantly higher in the North.

\section{Financing of the NHS}

141. The financing of the NHS in Italy was until very recently characterized by deliberate ex ante underfunding (in the budget), large deficits, and frequent bailout operations.

Underfunding was seen as a means to put downward pressure on health care expenditure, as it was difficult to identify and measure the factors which determined the demand for and the cost of delivering health care services ${ }^{71}$ and local health units had little incentive to control costs. With the exception of 1995, actual health care expenditure exceeded projections in each year between 1993 and 1997 (see CTSP, Table 1.2). The ensuing arrears and debts of the local health units were periodically taken over by the central government (eight times during the period 1980-1997), balancing health care financing and expenditure in an ex post manner. Thus the periodic reduction (elimination) of the accumulated liabilities of the local health care units became a structural element of health care finance in Italy.

142. Table 12 shows the financing structure of the NHS for 1993-97. Until 1992, financing was exclusively from the central government budget through the national health fund (Fondo Sanitario Nazionale, FSN). To enhance fiscal responsibility at the regional level, the health care contributions were assigned to the regions in 1993 and regions were given the right to increase the rate of contribution-none of them actually exercised this right, however, even though all recorded a deficit. Moreover, co-payments (ticket) were introduced. As described above, these steps failed to strengthen fiscal discipline. The 1997 tax reform replaced health contributions (as well as other local and central business taxes) with a local business tax (IRAP), and introduced a regional personal income tax. The most recent reform replaces the budget transfer to the health care fund (FSN) with a share of VAT revenue assigned to the regions.

143. Prior to the most recent reform, the allocation of the (ex-ante) available financing to the regions was based on a formula, and was decided by the Interministerial Committee on Economic Planning (CIPE). The formula, however, was changed practically every year, and the set of relevant variables changed five times during the last two decades. Between 1992

\footnotetext{
${ }^{70}$ Survey results on the subjective evaluation of the quality of public services show a strongly significant difference between the South and the North (see Table 5 in Alesina and others, 1999), with public health care services rated as one of the lowest quality public services in the South.

${ }^{71}$ Reliable microlevel data, on which empirical analysis of these factors could have been (or could now be) based, were (and still are) not available, at least not to the experts outside the Ministry of Health care (see CTSP, 1999; Reviglio, 2000).
} 
and 1996 the financing was practically distributed on a pro-capita basis. In 1997 an index of demand for health care services, reflecting the age structure and health condition of the population was introduced.

144. The actual outcome of the allocation process was a very even distribution of per capita (ex ante) financing. However, the actual deficits were very unevenly distributed across regions. The bail-out operations distributed ex post finance more or less in proportion to the accumulated liabilities; thus the regions in the North-East and the Center effectively managed to finance their historically higher levels of health care spending. The amount of (ex post) financing channeled to the regions through the bailout operations was considerable (CTSP, 1999). This resulted in a loss of credibility for the allocation mechanism through which ex ante financing levels were determined and in a very nontransparent and unstable system of ex post health care financing (Reviglio, 2000)

\section{Potential problems of decentralization}

145. The decentralization of the management of the public health care services will imply a major change in the role of regional governments. The initial positions of individual regions will be rather different, as local health units in the South are less efficient than those in the North. Due to the existing labor market regulations, the degree of overstafting, and the size of the public sector wage premium ${ }^{72}$ in the South, it will be difficult to reduce employment and introduce more flexible labor contracts in order to lower unit labor cost. A weak local economy could make this process even slower.

146. Local health units in the South rely more on contracted private health care services and have to devote a higher share of expenditure to pharmaceuticals, cost items which tend to increase fast. Because of the large share and downward rigidity of wage costs, they will find it difficult to counterbalance this increase. As their capacity to rajse additional own revenue is very limited (see Section III.E), they will have to either (i) increase co-payments and/or reduce the level of public health care serrices, or (ii) ask for higher transfers. This will put increasing pressure on the central government to assign a higher share of tax revenue to the regions.

147. While more pronounced in the South, the inefficiency of local health units is by no means restricted to the South. Moreover, local health units in Central and North-Eastern Italy were the ones that exceeded their budget allocations by the widest margins. Thus, governments in these regions will also find it difficult to contain health care expenditure.

\footnotetext{
${ }^{72}$ Empirical research (Alesina and others, 1999) suggests that the public sector wage premium was above 26 percent in the South, compared to 19 percent at the national level, maitily explained by the rather uniform level of public sector wages throughout the country and the substantial difference in cost of living between the South and the Center-North.
} 
148. The reduction in the share of public health care expenditure in GDP achieved in the first half of the 1990s appears unsustainable without further reforms aimed at increasing the efficiency of local health units and containing the costs of purchased services and pharmaceuticals. It is not evident that regional governments are better placed to design and carry out such reforms than the central government-especially given the rather limited administrative capacity of some regional governments. Moreover, due to the highly centralized nature of the system so far, regional governments have accumulated very little experience with managing a health care system and they are likely to have less power to contain costs using administrative pressure. That is, while the transfer of this responsibility to regional governments may be expected to result in better and more cost efficient public health care services in the longer run, the transition is likely to be a difficult one.

\section{E. Revenues of Regional Governments}

149. Prior to the recent reform, intergovernmental fiscal relations in Italy had been characterized by a high degree of vertical imbalance, ambiguity over responsibility for financing expenditure, and lack of stability and transparency. ${ }^{73}$ Concerning the ordinary statute regions, the process started in the late 1970 s with the decentralization of the functions assigned to the regions in the constitution. This was however done without creating adequate tax bases for the regions, and their revenues, including transfers from the central government, were determined by ad hoc legislation.

150. Before 1992, ordinary regions had only low yielding own taxes amounting to less than 3 percent of their total revenue (Emiliani and others, 1997). Since then, several waves of $\operatorname{tax}$ reforms have gradually increased regional tax revenue (see Table 13). ${ }^{74}$ The first step was to attribute health care contributions and assign a motor vehicle tax and a surcharge tax on natural gas consumption to the regions in 1992. This was followed by the sharing of the excise on gasoline in 1995, and the assignment of a new regional business tax (IRAP) and a regional personal income tax (PIT) to the regions in 1997. By 1998, total tax revenue of the regions reached some 3.1 percent of GDP. Finally, the 1999 reform has introduced the sharing of VAT revenue, and increased the maximum regional PIT rate and the share of the gasoline excise revenue assigned to the regions.

151. In spite of the gradual increase in own tax revenue, however, the actual degree of fiscal autonomy enjoyed by the regions was very limited until recently. Health care contributions attributed to the regions, and later IRAP, were fully earmarked to finance health

\footnotetext{
${ }^{73}$ For a detailed discussion of intergovernmental fiscal relations prior to the recent reforms, see Emiliani and others (1997).

74 The table does not account for the different types of health care contributions, which were transferred to the regions in 1994, but were earmarked to finance health expenditure. In 1998, IRAP was also earmarked to finance health care expenditure.
} 
expenditure. Thus, regional governments had practically no power to decide on the allocation of the largest part of their revenue. Moreover, they enjoyed only a very limited degree of tax autonomy. The major change the recent reform will bring about in this respect will be the phasing out of earmarking of revenues and of the restrictions on the allocation of health care expenditure. The regions will be given an increased (though still rather limited) degree of tax autonomy and an almost complete freedom to allocate expenditure, provided they comply with minimum standards on health care services to be defined by the central government.

\section{Own revenues}

152. The information on the taxes of ordinary statute regions ${ }^{75}$ is summarized in Table 14 and the main regional taxes are described in the Appendix. IRAP, the regional business tax introduced in 1998 , is by far the most important source of own tax revenue for regional governments (Table 15). In 1998, it accounted for 74 percent of the total own tax revenue of the regions, or 2.2 percent of GDP.

153. In order to provide a cross-country perspective, Box 1 summarizes the current tax assignment arrangements for a selected group of EU countries.

154. Of some concern is that the tax base of TRAP is the most unequally distributed tax base across the regions (see Table 16 and Figure 9). The ratio between the region with the highest and lowest per capita IRAP revenue is higher than 3.5, reflecting the highly unequal distribution of productive activities covered by the tax net and also the significant differences in the regional structure of economic activity. ${ }^{76}$ The regional personal income tax was the third most important source of tax revenue for regions in 1998, amounting to some 6.5 percent of total own tax revenue, less than 10 percent of the revenue from IRAP. The distribution of per capita tax revenue from the regional PIT is much less unequal than that from IRAP, indicating the extent of income redistribution through the central govemment budget. Revenue from the motor vehicle tax and the shared excise on gasoline produced some 19.5 percent of total own tax revenues of the regions in 1998. Per capita tax revenues from these taxes are even less unequally distributed than the revenue from the regional PIT.

\footnotetext{
${ }^{75}$ In addition to the taxes shown in the table, there are a large number of minor regional taxes and rees, which are not discussed (such as for example, the fee on solid waste disposal, or the sharing of university enrollment fees). For a detailed list of taxes and fees collected by the individual regions, and for the revenue from these sources, see Corte dei Conti (1999), Volume II. Local health units collect a nonnegligible amount of coinsurance payment, which is basically a user fee for a service financed by the regional governments. Nonetheless, these payments are not recorded in the accounts of the regions.
}

${ }^{76}$ Agricultural businesses are subject to lower IRAP and the share of agriculture in GDP is significantly higher in the poorer regions. 


\section{The new system of equalization}

155. The 1999 framework law (Law 133/1999, Art. 10) abolished almost all previously existing state transfers to ordinary statute regions, inchuding the transfer from the FSN. The regions were fulty compensated with the tax measures described above, including the sharing of VAT. The law also introduced an equalization mechanism, which takes into account the existing differences among regions in fiscal capacity, need for health care services, and fiscal effort. At the beginning, the law allows only for the redistribution of the VAT revenue allocated to the regions, but in the future the shared excise may also be redistributed through the equalization fund. The law envisages a transition period, during which equalization will be (partly) based on historical levels of expenditure.

\section{B0x 1. Tax Assignments and Tax Autonomy at the Intermediate Level of Subnational Governments in Selected EU Countries}

No single rule can explain the existing tax assignments of internediate level subnational governments in the EU countries. They have been determined by a large number of social, political, and historical factors; moreover, they also depend on the expenditure responsibilities of subnational governments, which also greatly vary among EU countries. This Box summarizes the existing anangements in those EU countries where intermediste level subnational governments--states, regions, counties, or communities-have significant tax revenues or enjoy a considerable degree of tax autonomy.

Lander in Austria receives some 10 percent of general government tax revenue, almost exclusively through shared taxes. Sharing arrangements are fixed by federal laws for 4-5 years and changes to the arrangements are alweys negotiated between the federal government and the $\mathrm{L}$.ander. The major-shared taxes are VAT, wage tax, PIT, tax on interest (withheld), motor vehicle tax, and tax on mineral oil. Lunder in Germany obtain some 21.5 pereent of general government tax revenue mainly through shared taxes-PIT, CIT, and VAT-but also through own taxes, such as, taxes on wealth, estate, and transfer of title. They have no legal power to set tax rates or define tax bases, but have 8 strong influence on the law-making process due to their tepresentation in the upper house of the parliament. The tax assignments of the communities and regions in Belgium are derived from the constitution and constitutional laws. Cornmunities, the main responsibility of which is efucation, receive some 13 percent of general government tax reventue, almost entirely through shared taxes. The sharing arrangetnents can only be changed by a law. Regional governments, which have wide ranging economic policy responsibilities, recerve some 10 percent of general government tax revenue. The most important taxes they collect are a surcharge on the national PIT, an inheritance tax and transaction taxes.

In Denmark, counties obtain some 9 percent of general government tax revenue, dominantly through a county PIT, the tate of, which is set, each year depending on the level of outlays. The rest is from a property tax, the tax base and rate of which are determined by national legisiation. Counties in Sweden are in a ratzer similar position, they receive some 10.5 percent of general government tax revenus almost entirely through a flat rate county PIT with an average rate close to 10 percent. The tax rate is deternined by the local council, but the tax is collected by the central government and transferred to the counties

Spain has 17 autonomous regions and 2 autonomous cities that were formed on the basis of the new democratic constintion enacted in 1978. The constitution limits the tax antonomy of the regions. They receive some 5 percent of general govenment tax revenue, through ceded taxes-on wealth, inheritance, transfer of title, and dutiesgavemed by central govenment legislation which gives some tax autonony to the regions, and through shared taxes. The most important shared tax is the PIT, 15 percent of which is transferred as block grant. Another 15 percent of PIT is assigned to the regions, for which they can set the tax rate and can infroduce tax credits. The rules govening the sharing of other tax revenues may change depending on the transfer of new responsibilities to the regions. 
156. The actual amount of VAT revenue allocated to a region is determined by a formula which is the sum of four components. The first one is the share of the region in the total VAT revenue assigned to the regions according to the size of its population. The second one deducts 90 percent-the solidarity coefficient-of the difference between the potential own tax revenue of the region (excluding VAT) and the potential tax revenue the region would have if it had the average per capita potential own tax base. ${ }^{77}$ It is important to point out that the formula is based on the potential tax revenue and not the actual one-thus it sanctions lack of fiscal effort at the regional level. ${ }^{78}$ The third component adds the difference between the eligible health care expenditure of the region and the health care expenditure the region would have if it had the average eligible per capita health care expenditure. The Ministry of Health will determine the level of eligible expenditure by taking into account the defined uniform minimum standards, the regional need for health care services, and the acceptable costs of service delivery. This in principle should provide incentives for the regions to keep health care costs below the level determined as acceptable by the Ministry of Health. The last component adds 70 percent of the difference between the standardized nonhealth care cost of the region and the standardized nonhealth care cost the region would have if it had the average standardized cost. The standardization is based on a semi-logarithmic function fitted to historical per capita nonhealth care costs of the regions (as a function of population) and the formula uses the fitted value for the regions. This component is based on the empirical finding that there is a sizable economies of scale involved in the provision of nonhealth care public services in Italy. It does not reward the inefficiency of an individual region, as it uses the fitted values from a regression.

157. In 2001, the first year of the operation of the equalization fund, the actual amount of VAT revenue allocated to a region will be determined by its historical expenditure, that is, there will be no change in the financial situation of any of the regions. To put it differently, the amount of VAT revenue allocated to a region will be a weighted average of the amount determined on the basis of historical expenditure and the amount determined on the basis of the new formula, where the second component gets zero weight in the first year. Over the subsequent 12 years, the weight of the formula-based amount will gradually be increased, and by 2014 it will fully determine the amount of VAT allocated to a region.

\footnotetext{
${ }^{77}$ Average of the ordinary statute regions participating in the scheme.

${ }^{78}$ So far, this only applies to the motor vehicle tax, as the other taxes are collected by a contralized tax administration, but in the future, a larger role is envisaged for the regions in the collection of IRAP.
} 


\section{Potential problems}

\section{Tax assignment}

158. The conventional prescription of the public economics model (Bird, 1999) is less likely to produce sustainable results for Italy because regional governments have sizable expenditure responsibilities. Nonetheless, there are some well-established basic principles that tax assignments in Italy should follow (Bird, 1999 and Norregaard, 1997).

159. The new system of regional taxes in Italy meets the two basic criteria for subnational taxes. It makes the most affluent region practically fiscally autonomous, even if regional tax rates are set at the minimum levels stipulated in the law (Figure 10). Second, it imposes fiscal responsibility at the margin, at least on regions in the North. Nonetheless, there are several potential problems with this system.

160. In spite of its appealing technical features (Bird, 1999), IRAP does not seem an optimal choice as the main source of revenue for regional governments. As pointed out earlier, IRAP has the most unequally distributed tax base among the regional taxes. ${ }^{79}$ This creates a large built-in need for horizontal equalization, much larger than the existing degree of interregional income inequality would necessitate (Figure 11)-at the same time, the tax with the most equally distributed tax base, the VAT, is used for equalization. (Moreover, the fact that the equalization fund is limited to the shared VAT revenue effectively limits the extent to which vertical imbalances can be reduced.) Furthermore, the heavy reliance on a local business tax is somewhat questionable, as its share in total revenue of regional governments is clearly not in line with the share of regional expenditure benefiting local businesses. The benefit argument would clearly support a higher regional PIT (with a concomitant reduction in national PIT), ${ }^{80}$

161. On the other hand, IRAP has some appealing characteristics (Bird, 1999). Given its base, it is neutral with respect to factor mix and financing structure. Thus, it is not biased against employment and it is less subject to base erosion resulting from thin capitalization. It is less distortionary than some of the taxes it replaced (municipal business tax and local payroll taxes) and other forms of subriational business taxes common in other countries (such as, for example, nonresidential property tax). Its base is fairly wide, not only because it is an income-

${ }^{79}$ One of the newly established criteria for subnational taxes is that its tax base should be relatively evenly distributed (Norregaard, 1997).

${ }^{\text {B0 }}$ A higher regional PIT minimum rate had initially been considered. However, a significantly higher PIT rate would have resulted in a net increase in own revenue for Lombardia higher than the phased-out transfers. Given the principle of revenue neutrality, this would have resulted in a net transfer of budgetary resources from the central government to the regions, even though there was no change in the expenditure responsibilities of the regions. 
based value added tax, but also because it is paid by nonincorporated businesses as well. However, the present IRAP rate (range) appears rather high when compared to the rates on similar taxes in other countries.

162. The actual extent of fiscal autonomy is very limited in the poorer regions. Under the present legislation, regional governments can increase their total revenue (including the revenue from VAT) by some 16 percent on average by increasing the regional tax rates (for IRAP and the regional PIT) up to the allowed limits (Figure 12). This would seem to provide cotsiderable room for maneuver. However, due to the unequal distribution of regional tax bases, rich regions can increase their revenues by up to 23.5 percent (Lombardia), while poor regions by only around 8 percent.

163. It is not clear whether the new system can impose fiscal responsibility and/or preserve equal access to public health care services. An 8 percent increase in real expenditure would require the poor regions to fully exercise their right to increase the IRAP and the regional PIT rates, ${ }^{82}$ while rich regions could achieve the same increase by considerably lower rate increase. ${ }^{83}$ This would result in further distortions in business location and a further deterioration of the growth potential of the poor regions-the mobility of the tax base of IRAP may effectively limit tax rate increases in the poor regions. Given the uncertainties in projecting health care expenditure and the likely extent to which the growth of health care expenditure will exceed the growth of the regional tax base, poor regions may not be able to exercise fiscal responsibility. A continued sizable difference in growth performance among the regions would make this problem even more severe.

164. The administration of regional taxes is relatively easy. VAT and the excise on gasoline remain national taxes, thus they impose no extra administrative burden. IRAP is relatively easy to administer due to the subtraction method and can be administered centrally through the newly established single-tax return form. The regional PIT taxes the same base as the national PIT (IRPEF) and it is administered centrally, thus its collection involves limited additional administrative burden. With the exception of the motor vehicte tax, there is practically no additional compliance cost involved in paying local taxes. The fact that none of the regional taxes is deductible linits the potential for vertical spillovers.

${ }^{\mathrm{BL}}$ Calabria, the poorest ordinary statute region, by slightly more than 6 percent.

${ }^{82} \mathrm{By} /$ and 0.5 percentage point, to 5.25 and 1.4 percent, respectively. Calabria would not be able to reach such increase under the existing rules.

${ }^{83}$ If it is assumed that they increase IRAP and IRPEF revenue proportional to the tax base, the increase in IRAP and IRPEF surcharge rates would be 0.5 and 0.1 percentage point, respectively. 


\section{Horizontal equalization mechanism}

165. Figure 13 shows the total revenues that the regions will actually receive in 2001 (including VAT revenue), based on historical expenditure, and the total revenues that they would receive if the new formula was already in force. Both are highly equalized and the differences between the two do not seem large at first glance. Over time, however, some of the regions that will lose revenue because of the new formula may find it difficult to adjust, unless they reduce their expenditure. Veneto and Lazio have adequate own tax bases, thus even if they could not reduce expenditure it would be relatively easy for them to offset the loss of revenue due to the new formula by slightly increasing their IRAP and/or regional PIT rates. The same is not true for Campania and Calabria, which would have to increase their rates quite substantially. Over the next 13 years, therefore, these regions would need to either grow faster than the economy as a whole-thereby enlarging their tax base-or acquire the administrative capacity necessary to lower costs.

166. The new equalization mechanism has some appealing features. It links the total amount of money allocated to the equalization fund to the tax base of VAT, which is a rather elastic one. It effectively limits the extent of inequality in per capita total revenue across regions, due to the very high solidarity coefficient set by the law, and automatically redistributes resources when individual regions are subject to asymmetric shocks. ${ }^{84}$ It takes into account fiscal need and economies of scale in providing nonhealth care related public services, and promotes fiscal effort at the regional level.

167. However, its implementation requires the specification of a number of concepts defined in the law, which may give rise to technical difficulties and to disagreement between regions and central government. The potentially most contentious one is the definition of eligible health care expenditures, used to determine the average eligible cost and thus the distance from the average. Under the existing law on the national health service (legislative decree 502/92), this should be based on a uniform level of services to be provided across the country and an estimate for each region of the per capita cost of providing these services.

168. If the history of the allocation mechanism under the previous system ${ }^{85}$ is an indication, it will be extremely difficult to come to an agreement concerning this aspect of the equalization tnechanistm. The allocation formula between 1980 and 1997 changed practicalily every year, with five major changes that concerned the variables included in the formula and a change in the eoefficients in the other years. Such frequent changes clearly undermine the credibility of any formula-based redistribution of resources. The frequent changes are partly

\footnotetext{
${ }^{84}$ Simulation results (Gtarda, 2000) show that the equalization mechanism can cope with rather sizable negative and positive asymmetric shocks to individual regional economies.

${ }^{85}$ Which was based on transfers from the budget playing practically the same role as the redistributed VAT revenue
} 
explained by the scarcity of sound research results available on the basis of which such formula could be devised in Italy (CTSP, 1999). Thus, uniess the required empirical research is carried out soon, this component of the equalization formula is likely to be subject to frequent changes.

169. Significantly faster growth in the North for a longer period, a phenomenon observed during the last decade, would put some pressure on the mechanism, though in the coming decade this would require a change in the design orly if Lombardia grew significantly faster than the national average. The increase in regional tax rates that poorer regions would have to undertake in this case would however create further distortions in business location and would thus reduce their growth potentials.

170. The increase in health care expencitures that is projected to ensue from population aging could, however, pose a major threat to the sustainability of the system. A yeariy increase in real health care costs 1 percentage point higher than real GDP growth would create a sizable imbalance in the system within a decade ${ }^{86}$ While the affluent Northern regions could raise the required extra revenue by increasing their IRAP and regional PIT rates, none of the Southern regions would be able to do so. This thay lead to a continuous reform of the tax assignment and the equalization mechanism, which could reduce the credibility of the system and thus produce perverse incentives for the regions.

\section{F. Borrowing by Regions}

171. Regions can borrow from financial institutions, issue marketable securities, and borrow from the central government. Borrowing is allowed only to finance investments and total debt service cannot exceed 20 percent of own revenues. Historically, regions have borrowed from commercial banks and from the Cassa Depositi e Prestiti, a special government financial institution created to finance subnational governments and which refinances the extended loans issuing postal bonds in the retail market. In 1995, regions were allowed to issue bonds with a minimum maturity of five years-bonds can be denominated in foreign currency, but only if the exchange rate risk is fully hedged. The total amount of new bonds issued by the regions increased rapidly since then, reaching Lit 4 trillion in 1999 . At the end of 1999 , the total debt of the regions reached Lit 24.7 trillion, or 1.2 percent of GDP.

172. One of the central elements of the recent reforms of intergovernmental fiscal relations is the gradual replacement of government transfers with own revenues. This will substantially increase the borrowing capacity of regional governments. Given that the Internal Stability Pact limits the primary balance excluding investment spending (see below), this could leave room for a sizable fiscal expansion at the regional level.

\footnotetext{
${ }^{86}$ Results referred to here are from a simulation exercise which assumes the same GDP growth rate is the baseline scenario (for the period 2001-10) in the medium-term simulations presented in Chapter II.
} 


\section{G. The Internal Stability Pact}

173. Given the important role of subnational governments in determining the developments of Italian public finances, as well as their increasing degree of fiscal autonomy, it was natural for the government to attribute to them formal responsibility to contribute to meeting the fiscal discipline obligations undertaken by Italy in the context of EMU. This was done in 1998 by introducing, in the context of the medium-term economic and financial programming document (DPEF) for 1999-2001, the so-called Internal Stability Pact, and the Jelevant provisions were set out in Article 28 of Law 448 of December 23, 1998.

174. This section provides an assessment of the Italian Internal Stability Pact, and discusses the extent to which it can help reconcile the fiscal commitments under EMU with the increasing degree of fiscal decentralization. Box 2 briefly describes the equivalent arrangements prevailing in other selected EMU countries with a degree of fiscal decentralization comparable to Italy's - the cross-country comparison underscores the inherent tension between fiscal autonomy at the subnational level and the need to safeguard fiscal objectives at the general government level.

175. As originally formulated, the Internal Stability Pact applied to the three-year period 1999-2001, and stipulated that local governments should (i) improve their fiscal balance by Lit 2.2 trillion, or 0.1 percent of GDP in 1999; and (ii) maintain their balance at least at this improved level over 2000-01. The Lit 2.2 trillion improvement in the consolidated balance was distributed among the different levels of subnational governments-regions, provinces, and municipalities -in proportion to their respective levels of total expenditures. Within each level, individual subnational governments would have to contribute to the achievement of the objective in proportion to their level of primary current expenditure. The improvement in the fiscal balance was defined in reference to the overall balance projected on a current services (unchanged policies/legislation) basis, as estimated in the government's programming documents, and it implied an improvement of only some Lit 600 billion over the 1998 outturn. The fiscal balance was defined as in the Maastricht rules, except that it excluded investment spending. It should be pointed out that no sanctions were stipulated for cases of noncompliance, with one exception: should Italy incur the sanctions envisaged under the EC excessive deficit procedures, Law 448 states that these sanctions will be distributed across those general government entities which failed to fulfill their commitments.

176. During its first year of operation, 1999, the Internal Stability Pact is estimated to have yielded only half of the envisaged savings. Several modifications to the pact were therefore approved in late 1999, in the context of the new medium term plan for 2000-03 and the 2000 Budget Law. First of all, it was stipulated that subnational governments would improve their fiscal balance by Lit 3.3 trillion, or 0.15 percent of GDP in 2000, of which (i) Lit 1.1 trillion corresponding to the shortfall in savings for 1999; and (ii) Lit 2.2 trillion corresponding to a more ambitious target for 2000 than originally envisaged. The improvement achieved over 1999-2000 should then be maintained over the following three years (2001-03). Second, the revised Internal Stability Pact stipulates some changes to the relevant definition of the 
overall balance, including, importantly, that receipts from the sale of real estate assets should now be excluded from the definition of revenues. Third, following the revisions to the relevant definition of the overall balance, subnational governments are given a choice of three options under which their compliance with the Internal Stability Pact could be determined: (i) they could have their 1999 performance measured according to the old criteria, and the 2000 performance according to the new criteria; (ii) they could have their 1999 performance reassessed according to the new criteria; or (iii) they could have their performance assessed on a cumulated basis for the 1999-2000 period according to the new criteria.

\section{Box 2. Internal Stability Pacts in Selected EU Countries}

In most member states the fiscal target set ont in the Treaty on the European Union and the Stability and Growth Pact implies a sizable fiscal adjustment which is difficult to achieve without some form of coordination between the central and subnational governments. The actual form of the cocrdination, the way in which the fiscal targets for the diffierent levels of govenment are reached and documented, depend on a number of factors. In some countries it is a formal agreement between the central and subnational governments on how to distribute the burden of fiscal adjustment. The importance of such an agreement depends on the extent of the required adjustment and the size of subnational governments, while its legal form and technical details depend on the legel status of subnationel governments and the existing Jegal limitations on budget deficit and borrowing at the subnational level.

The first artangements between the national and regional govemnents in Spam were introduced in March I992 in the context of the convergence program. Though some of the details have been changed since ther, the arrangenents presently in force for the period 1997-2001 are very similar to the original ones. The arrangements are agreements between the central government and each subnational govenment, both at the regional and local level-there is no legal basis for their enforcement. The overall target for the consolidated fiscal position of the subnational governments, as well as individual targets in terms of overall deficits and debt, weje agreed upon through negotiations that took into account the evolving expenditure responsibilities and revenue assignments of the subnational governments involved. The agreements involve no sanctions or incentives, but debt issuance by subnational governments requires the approval of the central goverument, giving a leverage to the central government over those subnational govenments that do not comply. Despite the lack of a formalized enforcement mechanism and sanctions, subnational governments have met their targets in recent years.

Regions and commurities (so-called fedierated entities forming the intermediate level goverament) in Belgium are subject to the supervision of the High Finance Council, which issues an anmul report on the financial situation of each entity, examining its financial needs and recommending a maximum ceiling for its deficit. In its 1999 annual report, the High Finance Council set out recommendations for the overall balances of the federated entities for the period 2001-10. For entities in deficit (all regions and communities except the Flemish Community), a gradual move towards a balanced fiscal positions was recommended. In late 1999, at the regular consuitation of the federal government, the regions and the communities, these recommendations were accepted as policy targets for the period 2000-03. The agreement is only political in nature; legal sanctions can onily be imposed if the fiscal policy of an entity puts at risk the internal or extemal equilibrium of the national economy. Peer pressure among regions and communities is however an effective political mechanism through which agreements can be enforced. In addition, as mextioned above, regions and communities are subject to an annual examination by the High Financial Counoi?. Local governments (provinces and municipalitjes) are subject by law to a balanced budget constraint.

In Finland, though subnational governments enjoy a very high degree of fiscal alstonomy - their combined shares in general government revenue and expenditure are very high, and they face practically no restriction on borrowing-. there is no formal agreement setting out targets for the fiscal positions of subnational governments. The reason is that local governments (practically the only existing level of subnational government) have traditionally pursued very conservative fiscal policies, thus the need for such agreenent did not arise. 
177. No new sanctions for noncompliance have been approved, however. As an incentive to comply, on the other hand, it has been decided that subnational governments meeting the objectives of the Internal Stability Pact will be granted a reduction on the interest on their outstanding debts to the Cassa Depositi e Prestiti. Even this incentive, however, seems undermined by the recent decision to grant to all regions an unconditional reduction. Against the background of increased devolution of fiscal responsibility to local governments, the Internal Stability Pact seems still to be interpreted more as a framework to foster cooperation between central and local governments rather than as an instrument for the former to impose fiscal discipline on the latter.

178. The fairly rigid rules imposed by the Maastricht Treaty, relying on numerical parameters that have to be observed ex post, inevitably creates a tension with the flexibility involved in delegating fiscal responsibility to subnational governments. An important question is therefore to what extent the Internal Stability Pact can help Italy reconcile the fiscal commitments undertaken with membership in EMU with the increasing degree of fiscal decentralization. ${ }^{87}$ In this regard, the Internal Stability Pact in its current form is less than ideal in several respects. First and foremost, the lack of strong and credible sanctions leaves wide room for free riding by individual subnational governments. As was mentioned above, the pact stipulates that, should Italy incur in the financial penalties implied by the excessive deficit procedure, the subnational governments that failed to comply with the Internal Stability Pact would have to share the penalty in proportion to their degree of noncompliance. However, the reputation cost that would ensue from breaching the Maastricht deficit ceiling would be felt disproportionately by the central government. This could generate in subnational governments the expectation that any overshooting on their part would be compensated by the state. Even the financial penalty may not be credible in the case that few subnational governments were responsible for the breach, as their share of the penalty could be excessive. Moreover, to the extent that a breach of the Maastricht ceiling appears unlikely, the current system fails to provide any sanctions against free riders. A second shortcoming of the Internal Stability Pact lies in the fact that it targets a definition of the fiscal balance different from the Maastricht definition, which is the one that must ultimately be kept under control at the general government level. A third limitation of the pact is that it does not attempt to deal with the impact of the cycle on the budgets of subnational governments, just as new changes to the tax assignment framework make these budgets more cyclically sensitive than ever before. Finally, distributing the required effort across subnational governments in proportion to their levels of primary current expenditures appears questionable: not only does a government which is already running a surplus have to contribute to the effort, but if its level of current primary expenditures is high, it may be required a larger effort than a government running a (perhaps large) deficit.

\footnotetext{
${ }^{87}$ For a more detailed discussion of the interaction between international fiscal obligations and domestic intergovernmental fiscal relationships, see Balassone and Franco (1999).
} 


\section{H. Conclusions}

179. The reform of intergovernthental fiscal relations has so far concerned the tax assignment of the regions and the system of horizontal ecuualization. It has created a larger regional tax base and a transparent and, at least at the outset, adequately sized system of horizontal equalization. These steps could go some way towards strengthening transparency of intergovernmental relationships. However, the reform has not yet addressed the need for stemming the future expenditure demands related to population aging. Moreover, there are several elements of the new system of intergovernmental relations that may limit the positive impact of the reform.

180. The increased regional tax base is very unevenly distributed, because of the large share of IRAP in total own revenues of the regions, thus limiting the ability of poorer regions to raise additional revenues and forcing them to rely on the transfer from the equalization fund to a considerable extent. Given their initial expenditure structure, these regions will thus have very little real fiscal autonomy. At the same time, richer regions will be able to generate substantial amounts of additional revenue by exercising their tax autonomy, and will hence be able to provide better services, if their constituencies decide to do so. This could exacerbate the regional differences in provision of health care services--although the setting of minimum standards should still guarantee nationwide access to a set of core services.

181. The extent to which fiscal responsibility can be fostered in the poorer regions is also circumscribed by their limited capacity to finance an increase in expenditure. Continued slower growth in the South or a rapid increase in health care costs, two developments not unlikely to take place in the coming years, could further aggravate this problem. While in principle the system can cope with the consequences of continued slow growth in the South, the required regional tax rate increases would further reduce the growth potential of regions in the South and thus eventually undermine the stability of the system. Imposing fiscal responsibility upon the regions could be self-defeating in such a case.

182. Increasing the regional tax base or the size of the equalization fund to finance rising health-care costs could create two problems. First, it might reduce the credibility of the system. In order to foster fiscal responsibility at the regional level, the system has to establish hard budget constraints, that is, it has to limit the tax base assigned to the regions. An increase in the tax base may be justifiable only to the extent that the expenditure increase stems from factors beyond the regions' control, and it may be hard to identify this in a credible manner. Second, without a change in the design, it will be technically difficult to increase the resources available to the regions in a way that properly targets the regions in need of additional revenue. Changing the design would, however, also raise the issue of credibility.

183. Assigning the responsibility of financing and managing the health care system to the regions may increase the allocative efficiency and the productivity of the health care system but-similarly to the decentralization of other fiscal activities-only if certain conditions are met (Tanzi, 1995). Decentralization will lead to an improvement in public services only if 
subnational governments have the necessary administrative capacity to manage the provisioning of the services in an efficient manner. The initial situation in some of the regions may be far from this (Putnam, 1993 and Tanzi, 1995). In fact, it seems that institutional capacities will be needed most in regions where they are least available. The quality of public expenditure management at the regional level, a particularly important aspect of the quality of regional administrations, is also a factor that may limit the benefits from decentralization (Tanzi and others, 1994). Finally, it is questionable whether the spatial characteristics of health care services make the regions the right level of government to assign this responsibility to (in this respect, however, there is very little choice because the responsibility for providing health care services is assigned to the regions in the constitution).

184. Decentralization is deepening at a time when the capacity of the regional budgets to contain the increase in costs is likely to be critical. As argued above, due to the way the health care system has been managed so far, even regions with strong administrations have little experience with this, compared to the central government, and there is a risk that regions may be less able to exert administrative pressure on the health care system to contain costs.

185. Therefore, in order to make the recent reform successful and to fully utilize the sizable potential gain from decentralization, measures aimed at building the necessary institutional capacity at the regional level are urgently needed. A radical improvement of human resource management in the public sector is an important building block of the Bassanini reform; it is of great importance to ensure that such improvement takes place also at the regional level, especially it the regions in the South.

186. A comprehensive reform of the health care system, which will now be designed and carried out at the regional level, is also needed. The reform should create strong incentives for the local health units to reduce costs. It should also create mechanisms through which best practices can be transferred to regions where local health units are less efficient. This should result in a higher level of transparency concerning the performance of individual local health units, allowing regional administrations to rely on nationwide benchmarks when assessing the performances of local health units in their regions.

187. Finally, faster and more evenly distributed growth is perhaps the best way of making the reform of intergovernmental fiscal relations successful. Policy measures aimed at achieving this-discussed in the main report-appear even more important in this light. 
Table 1. Italy: Key Characteristics of Regions

\begin{tabular}{|c|c|c|c|c|c|c|c|}
\hline & \multicolumn{2}{|l|}{ Area } & \multicolumn{2}{|c|}{ Population } & \multirow{2}{*}{$\begin{array}{l}\text { Population } \\
\text { Dersity } 1 /\end{array}$} & \multicolumn{2}{|c|}{ Population Age 65 and Older } \\
\hline & Square Kilometers & Percent of Total & Total & Percent of Total & & Total & Percent of Total \\
\hline Piemonte & 25,399 & 8.4 & $4,291,441$ & 7.5 & 169 & 852,007 & 19.9 \\
\hline Valle d'Aosta & 3,263 & 1.1 & 119,610 & 0.2 & 37 & 21,771 & 18.2 \\
\hline Lombardia & 23,861 & 7.9 & $8,988,951$ & 15.6 & $377^{\circ}$ & $1,516,418$ & 16.9 \\
\hline Trentino Alto Adige & 13,607 & 4.5 & 924,281 & 1.6 & 68 & 152,298 & 16.5 \\
\hline Veneto & 18,391 & 6.1 & $4,469,156$ & 7.8 & 243 & 776,786 & 17.4 \\
\hline Friuli Venezia Giulia & 7,855 & 2.6 & $1,184,654$ & 2.1 & 151 & 247,552 & 20.9 \\
\hline Liguria & 5,421 & 1.8 & $1,641,835$ & 2.9 & 303 & 393,962 & 24.0 \\
\hline Emilia-Romagna & 22,124 & 7.3 & $3,947,102$ & 6.9 & 178 & 856,658 & 21.7 \\
\hline Toseana & 22,997 & 7.6 & $3,527,303$ & 6.1 & 153 & 757,735 & 21.5 \\
\hline Umbria & 8,456 & 2.8 & 831,714 & 1.4 & 98 & 179,748 & 21.6 \\
\hline Marche & 9,694 & 3.2 & $1,450,879$ & 2.5 & 150 & 302,498 & 20.8 \\
\hline Laxio & 17,207 & 5.7 & $5,242,709$ & 9.1 & 305 & 859,380 & 16.4 \\
\hline Abruszo & 10,798 & 3.6 & $1,276,040$ & 2.2 & 118 & 241,388 & 18.9 \\
\hline Motise & 4,438 & 1.5 & 329,894 & 0.6 & 74 & 64,565 & 19.6 \\
\hline Campania & 13,595 & 4.5 & $5,796,899$ & 10.1 & 426 & 750,457 & 12.9 \\
\hline Puglia & 19,363 & 6.4 & $4,090,068$ & $7_{-1}$ & 211 & 590,565 & 14.4 \\
\hline Basilicata & 9,992 & 3.3 & 610,330 & 1.1 & 61 & 102,189 & 16.7 \\
\hline Calabria & 15,080 & 5.0 & $2,070,992$ & 3.6 & 137 & 322,314 & 15.6 \\
\hline Sicilia & 25,710 & 8.5 & $5,108,067$ & 8.9 & 199 & 782,523 & 15.3 \\
\hline Sardegna & 24,090 & 8.0 & $1,661,429$ & 2.9 & 69 & 241,232 & 14.5 \\
\hline Italy & 301,341 & 100.0 & $57,563,354$ & 100.0 & 191 & $10,012,046$ & 17.4 \\
\hline Center-North & 178,275 & 592 & $36,619,635$ & 636 & 205 & $6,916,813$ & 18.9 \\
\hline South & 123,066 & 40.8 & $20,943,719$ & 36.4 & 170 & $3,095,233$ & 14.8 \\
\hline
\end{tabular}

Sowrce: ISTAT.

1/ Irhabitants for square kilometers.

(C)International Monetary Fund. Not for Redistribution 
Table 2. Italy: Regional Labor Market Indicators

\begin{tabular}{lrr}
\hline & $\begin{array}{r}\text { Participation } \\
\text { Rate }\end{array}$ & $\begin{array}{r}\text { Unemployment } \\
\text { Rate }\end{array}$ \\
& & \\
\hline Piemonte & 63.1 & 8.6 \\
Valle d'Aosta & 66.3 & 5.5 \\
Lombardia & 61.9 & 6.0 \\
Trentino Alto Adige & 65.1 & 2.5 \\
Veneto & 62.8 & 5.3 \\
Friuli Venezia Giubia & 62.1 & 6.8 \\
Liguria & 60.2 & 11.4 \\
Emilia-Romagna & 67.7 & 6.0 \\
Toscana & 62.5 & 8.5 \\
Umbria & 59.9 & 8.8 \\
Marche & 63.3 & 7.4 \\
Lazio & 57.0 & 12.5 \\
Abruzzo & 58.3 & 9.3 \\
Molise & 59.7 & 17.2 \\
Campania & 51.7 & 25.8 \\
Puglia & 50.4 & 19.2 \\
Basilicata & 52.5 & 19.3 \\
Calabria & 50.2 & 24.3 \\
Sicilia & 50.6 & 24.3 \\
Sardegna & 53.5 & 21.0 \\
& & \\
Italy & 58.4 & 12.3 \\
Center-North & 62.2 & 7.6 \\
South & 51.7 & 22.2 \\
& & \\
\hline & & \\
\hline
\end{tabular}

Source: ISTAT (1996).

CInternational Monetary Fund. Not for Redistribution 
Table 3. Italy; Regions' Contributions to GDP, 1980-96

\begin{tabular}{|c|c|c|c|c|c|c|c|c|c|c|c|c|c|c|c|c|c|}
\hline & 1980 & 1981 & 1982 & 1983 & 1984 & 1985 & 1986 & 1987 & 1988 & 1989 & $19 \%$ & 1591 & 1992 & 1993 & 1994 & 1995 & 1996 \\
\hline Fiemonte & 9.4 & 9.3 & 9.1 & 9.0 & 8.9 & B.9 & 8.9 & 8.9 & 89 & 8.9 & 8.8 & 8.6 & 8.5 & 8.4 & 8.5 & 8.6 & 8.6 \\
\hline Valle d'Aosta & 0.3 & 0.3 & 0.3 & 0.3 & 0.3 & 0.3 & 0.3 & 0.3 & 0.3 & 0.3 & 0.3 & 0.3 & 0.3 & 0.3 & 0.3 & 0.3 & 0.3 \\
\hline Lumbardia & 20.5 & 20.6 & 20.4 & 20.2 & 20.0 & 202 & 20.4 & 20.2 & 20.4 & 20.5 & 20.3 & 20.0 & 19.8 & 19.7 & 19,9 & 20.1 & 20.1 \\
\hline Treminn Alto Adige & 18 & 1.8 & 1.8 & 1.8 & 1.9 & 1.8 & 1.8 & 1.8 & 1.9 & 1.9 & 1.9 & 1.9 & 1.9 & 2.0 & 2.0 & 20 & 2.0 \\
\hline Venteto & 8.5 & 8.5 & 8.5 & 8.5 & 8.6 & B. 5 & 8.6 & 8.7 & 8.T & 8.8 & 8.7 & 8.7 & 8.9 & 9.1 & 9.1 & 9.3 & 9.4 \\
\hline Friuli Venezin Givlia & 2.5 & 2.5 & 2.4 & 2.4 & 24 & 24 & 2.4 & 2.4 & 2.4 & 2.4 & 2.4 & 2.4 & 2.4 & 2.4 & 2.5 & 2.6 & 2.5 \\
\hline Liguris & 3.6 & 3.5 & 3.5 & $\mathbf{3 . 4}$ & 3.5 & 3.5 & 3.5 & 3.4 & 3.4 & 3.4 & 3.4 & 3.4 & 34 & 3.4 & 3.4 & 3.4 & 3.4 \\
\hline Ermilia-Romagnt & 9.2 & 9.3 & 9.1 & 8.8 & 8.8 & R. 6 & 8.6 & 8.6 & 8.6 & 8.6 & 8.6 & 8.5 & 8.7 & 3.7 & 8.7 & 3.8 & 8.9 \\
\hline Tascana & 7.0 & 7.1 & 7.2 & 7.0 & 69 & 7.0 & 6.9 & 6.8 & 6.7 & 6.7 & 6.6 & 6.6 & 6.6 & 6.6 & 6.6 & 6.6 & 6.6 \\
\hline Umbria & 1.4 & 1.4 & 1.4 & 1.4 & 1.4 & 1.4 & 1.4 & 1.3 & 1.3 & 1.4 & 1.4 & 1.4 & 1.4 & 1,4 & 2.4 & IA & 1,4 \\
\hline Marche & 2.7 & 2.7 & 2.7 & 2.6 & 2.6 & 26 & 2.6 & 26 & 2.6 & 2.6 & 2.6 & 26 & 2.6 & 2.6 & 2.6 & 2.6 & 26 \\
\hline Lazio & 9.0 & 9.0 & 9.2 & 9.5 & 9.6 & 9.7 & 9.9 & 10.0 & 9.9 & 9.8 & 10.0 & 10.1 & 10.2 & 10.2 & 10.1 & 10.0 & 100 \\
\hline Abruza & 1.8 & 1,8 & 1.9 & 1.9 & 1.9 & 1.9 & 1.9 & 1.9 & 1.9 & 1.9 & 1.9 & 2.0 & 3.0 & 20 & 1.9 & 2.0 & 19 \\
\hline Molise & 0.4 & 0.4 & 0.4 & 0.4 & 0.4 & 0.4 & 0.4 & 0.4 & 0.4 & 0.4 & 0.4 & 0.4 & 0.4 & 0.4 & 0.4 & 0.4 & 0.4 \\
\hline Campenis & 6.4 & 6.4 & 6.7 & 6.8 & 6.8 & 6.8 & 6,6 & 6.7 & 5.7 & 6.7 & 6.8 & 6.7 & 67 & 6.7 & 6.6 & 6.4 & 6.5 \\
\hline Puglia & 4.9 & 4.7 & 4.7 & 49 & 49 & 4.9 & 4.9 & 4.9 & so & 5.0 & 5.0 & 5.1 & 5.0 & 49 & 5.0 & 49 & 4.9 \\
\hline Basilicata & 0.7 & 0,7 & 0.7 & 0.7 & 07 & 0.7 & 0.7 & 0.7 & 0.7 & 0.7 & 0.7 & 0.7 & 0.7 & 0.7 & 0.7 & 0.7 & 0.7 \\
\hline Calabria & 2.5 & 2.2 & 2.2 & 2.3 & 2.2 & 2.3 & 2.2 & 2.2 & 2.1 & 2.2 & 2.1 & 22 & 2.1 & 2.2 & 2.1 & 2.1 & 21 \\
\hline Sicilia & 5.7 & 5.7 & 5.8 & 6.1 & 6.1 & 5.9 & 6.0 & 6.1 & 5.9 & 5.8 & 5.9 & 6.1 & 6.0 & 6.1 & 5.9 & 5.8 & 5.7 \\
\hline Sardegna & 2.0 & 2.0 & 2.0 & 2.1 & 2.2 & 2.1 & 2.1 & 2.1 & 2.1 & 2.1 & 2.1 & 2.2 & 2.2 & 2.3 & 2.2 & 2.1 & 2.1 \\
\hline Italy & 100.0 & 100.0 & 100.0 & 1000 & 1000 & 1000.0 & 1000 & 1000 & 100.0 & 100.0 & 180.0 & 100.0 & 160.0 & 160.0 & 100.0 & 100.0 & 1000 \\
\hline Center-Worth & 75.9 & 76.0 & 75.7 & 75.0 & 74.9 & 75.0 & 75.2 & $75 . a$ & 75.1 & 75.2 & 75.0 & 747 & 74.8 & 74.8 & 75.1 & 75.6 & 75.7 \\
\hline South & 24.1 & 24.0 & 24.3 & 25.0 & 25.1 & 25.0 & 24.8 & 25.0 & 24.9 & 24.8 & 250 & 25.3 & 25.2 & 25.2 & 24.9 & 24.4 & 24.5 \\
\hline
\end{tabular}

Sourre: ISTAT 


\section{$-111-$}

Table 4. Italy: Regional Per Capita GDP, 1996

\begin{tabular}{lrr}
\hline & In millions of lire & $\begin{array}{r}\text { As Percent of } \\
\text { National Average }\end{array}$ \\
\hline Piemonte & & \\
Valle đ'Aosta & 36.9 & 115.2 \\
Lombardia & 42.3 & 132.1 \\
Trentino Aito Adige & 41.6 & 129.8 \\
Veneto & 41.1 & 128.3 \\
Frivili Venezia Giulia & 39.3 & 122.8 \\
Liguria & 39.8 & 124.1 \\
Emilia-Romagna & 37.3 & 116.3 \\
Toscana & 41.9 & 130.8 \\
Umbria & 34.9 & 108.8 \\
Marche & 30.6 & 95.4 \\
Lazio & 33.9 & 105.7 \\
Abruzzo & 35.7 & 111.3 \\
Molise & 28.0 & 87.5 \\
Campania & 24.1 & 75.4 \\
Puglia & 20.1 & 62.7 \\
Basiticata & 22.2 & 69.3 \\
Calabria & 20.9 & 65.3 \\
Sicilia & 18.1 & 56.6 \\
Sardegna & 20.0 & 62.3 \\
& 23.1 & 71.9 \\
Italy & & \\
Center-North & 32.0 & 100.0 \\
South & 38.5 & 120.1 \\
& 21.1 & 65.7 \\
\hline & & \\
\hline
\end{tabular}

Source: ISTAT 
(In butions of lire)

Total revernules:

Current tewentues

Ter revenues

Tzansfors Fons state and other public institutions Ober surrani reve

Frorn olher public institutions

$$
\text { other }
$$

Totel texpentitures

Wayes and sakri

Gonds and services

Thanslers to pubtic institution

Social taristers

Thoduction sabsitties

Other curnent

Capilal expenditures

Overall balusice

Total reventuess

Current reventues

Transfiers firom stots und other publia institutions Other cursent rcveruec

Capitad reverntes

Prost oller publie veretiations

Total expenditures

Current expenditiutes

Gookits end sevives

Transfers to public institution

Soxisil transfers

Mandertion sabsidies

Other aurent

Capian

Cappratl expenditines

Investinent subsities

Other

Chefat balante

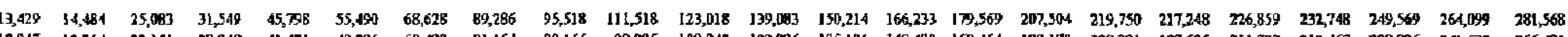

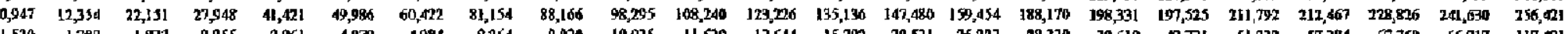

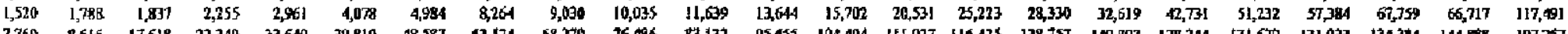

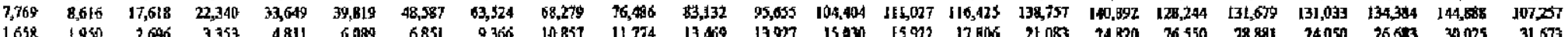

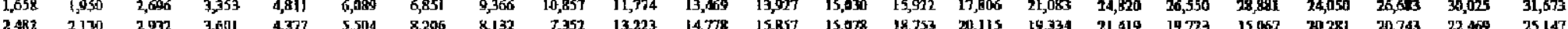

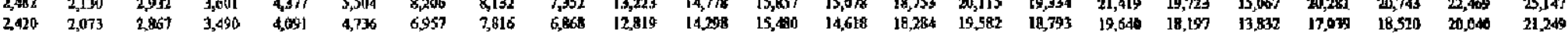

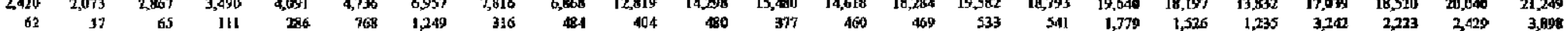

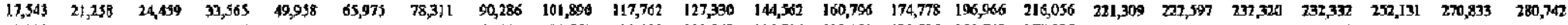

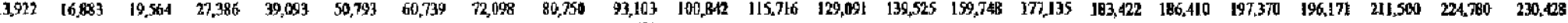

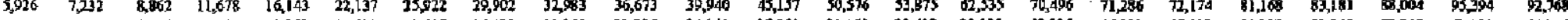

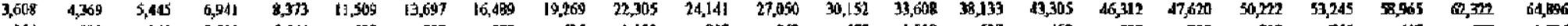

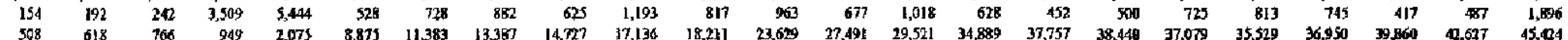

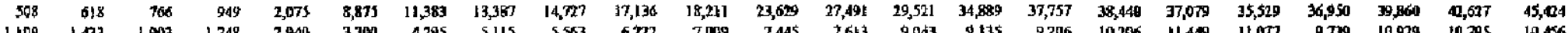

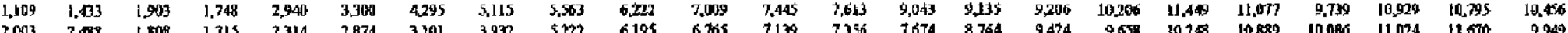

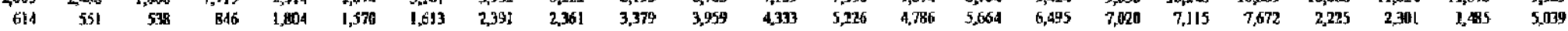

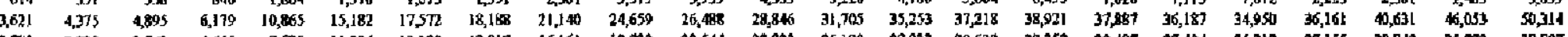
$\begin{array}{llllllllllllll}18,729 & 20,544 & 22,923 & 25,190 & 37,933 & 29,532 & 30,352 & 29,487 & 27,494 & 26,212 & 27,155 & 30,843 & 33,273 & 36,997\end{array}$

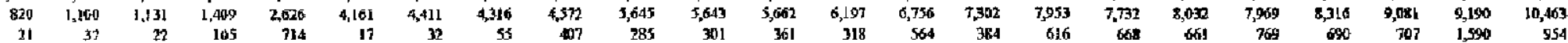

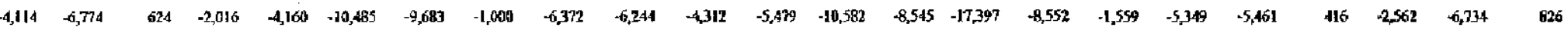

\section{(In pecest of GDP)}

\begin{tabular}{|c|c|c|c|c|c|c|c|c|c|c|c|c|c|c|c|c|c|c|c|c|c|c|}
\hline 17 & 6.7 & 9.9 & 10.2 & 11.IE & 6.9 & 126 & [4.] & 13.2 & 13.7 & 13.7 & 14.I & 137 & 13.9 & 13,6 & 14,4 & 14.5 & 139 & 23.7 & 13.0 & 13.1. & 133 & 13.6 \\
\hline 6.2 & 5.8 & 8.7 & 9.0 & 10.7 & 10.7 & 11.1 & 12.8 & 12.1 & 12.1 & 12.0 & 12.5 & 12.4 & 12.3 & 121 & 13.1. & 13.1 & 12.6 & 12.8 & 11.9 & 12.0 & 12.2 & 12.4 \\
\hline 0.9 & 0.8 & 0.9 & a. & 0.8 & 0.5 & 0.9 & 1.3 & 1.2 & 1.2 & 1.3 & 1.4 & 1.4 & 1.7 & 1.9 & 20 & 2.1 & 2.7 & 3.1 & 3.2 & 3.6 & 3.4 & 5.7 \\
\hline 44 & 9.0 & 5.9 & 7.2 & 8.7 & 8.6 & 8.0 & 10.0 & 9.4 & 9.4 & 9.2 & 9.7 & 9.6 & 9.3 & B.8 & 9.6 & 9.3 & 81 & 800 & 7.3 & 7.1 & 7.3 & 5.2 \\
\hline 0.9 & 0.9 & 11 & 31.1 & 1.2 & 1.3 & 1.3 & 1.5 & 1.5 & 1.4 & 1.5 & 1.4 & 1.4 & 1.3 & 13 & 1.5 & 1.6 & 1.7 & 1.7 & 1.3 & 1.4 & 1.5 & 1.5 \\
\hline 1.4 & 1.9 & 1.2 & 1.2 & i.t & 1.1 & 1.5 & 1.3 & 1.0 & 1.6 & 16 & 1.6 & $1 . A$ & 1,6 & 1,5 & 1.3 & 1.4 & 2.3 & 00 & 1.1 & 11 & 1.4 & 17 \\
\hline 1.4 & 1.0 & 1.1 & 31 & 1.1 & 1.0 & t. 3 & 1.3 & 0.9 & 1.6 & 1.6 & 1.6 & 1.3 & 1.5 & 1.5 & 1.3 & 1.3 & 1.2 & $\mathrm{OB}$ & 1.0 & 10 & i.D & 1.0 \\
\hline 0.0 & 0.0 & 0.0 & 0.0 & 0.1 & 0.2 & 0.2 & 0.0 & 0.1 & 0.0 & 0.1 & 0.0 & 0.0 & 0.0 & 0.6 & 0.0 & 0.1 & 0.1 & 0.1 & 0.2 & 0.1 & 0.1 & 0.2 \\
\hline 10.0 & 9.9 & 9.6 & 10.8 & 12,9 & 14,2 & 14.4 & 14.3 & 180 & 143 & $|4|$ & 14.7 & 14.7 & 14.6 & 14.9 & 13.0 & 14.5 & 14.2 & 14.1 & 13.0 & 193 & 19.7 & 13.6 \\
\hline 79 & 7.9 & 7.7 & 8.8 & 10.1 & 18.9 & 11.2 & 11.4 & 11.1 & 11.4 & 11.2 & 11.8 & 11.8 & 11.7 & 12.1 & 12.3 & 13.1 & 119 & 11.9 & 110 & 11.1 & 11.3 & ILI \\
\hline 3.4 & 3.4 & 3.5 & 3.8 & 4.2 & 4.8 & 4.8 & 4.7 & 4.5 & 4.5 & dit & 46 & 4.6 & 4.5 & 4.7 & 4.9 & 4.7 & 46 & 49 & 4.7 & 4.6 & 4.8 & 4.5 \\
\hline 2.1 & 20 & 2.1 & 2.2 & 22 & 2.5 & 2.5 & 1.6 & 2.7 & 2.7 & 27 & 27 & 2.8 & 2.8 & $\mathbf{3 , 9}$ & 3.0 & 3.1 & 30 & 3.0 & 30 & 3.1 & $3 \mathrm{II}$ & 3.1 \\
\hline 0.6 & 0.1 & 0.1 & 1.1 & 1.4 & 0.1 & 0.1 & 0.1 & 0.1 & 0.1 & $a_{1}$ & 0.1 & 0.1 & 0.1 & 0.0 & 0.0 & 0.9 & 0.0 & $0: 0$ & $\infty, 0$ & 0.0 & 0.0 & 0.1 \\
\hline 0,3 & $\mathbf{0 . 3}$ & $a .3$ & 03 & a.s & 1.9 & 2.1 & 2.1 & 2.0 & 2.1 & 20 & 24 & 2.5 & 2.5 & 2.6 & 2.6 & 2.5 & 2.4 & 2.1 & 21 & 2.1 & 25 & 21 \\
\hline 0.6 & 0.7 & 0.7 & 06 & t..8 & 0.7 & 0.8 & 0.8 & 0.8 & 0.8 & D.B & 0.8 & 0.7 & 0.8 & 0.7 & 0.6 & 0.7 & 0.7 & 0.7 & 0,5 & 0.6 & of & 0,5 \\
\hline l.t & 1.2 & 0.7 & 0.6 & 0.6 & 0,6 & 0.6 & 0.6 & 0.7 & 0.8 & 0.8 & a. & 0.7 & 0.6 & $0 . \tau$ & 0.7 & 0.6 & 0.7 & 0.7 & 16 & 0.6 & 0.6 & 85 \\
\hline 0.4 & 09 & 0.2 & 03 & 0.5 & 0.3 & 0.3 & 0.4 & 0.3 & 0.4 & 0.4 & 0.4 & 0.5 & 0.4 & 0.4 & 0.5 & 0.5 & 0.5 & 0.5 & .1 & 0.1 & 0.1 & 0.2 \\
\hline 2.1 & 2.0 & 1.9 & 20 & 28 & 3.3 & 3.2 & 29 & 29 & 3.0 & 29 & 29 & 2.9 & 2.9 & 2.8 & 2.7 & 2.5 & 1.3 & 2.1 & 20 & 2.1 & 23 & 2.4 \\
\hline 1.0 & 1.3 & 1.5 & 1.5 & 1.9 & 2.4 & 2.4 & 2.2 & 22 & 2.3 & 2.3 & 23 & 2.3 & 2.3 & 2.2 & 2.1 & 1.9 & 1.8 & 1.6 & 1.5 & 16 & 18 & 1.9 \\
\hline 0.5 & os & 0.4 & 0.5 & 0.7 & 0.9 & 0.8 & $\mathbf{p}^{\mathrm{T}} \mathrm{T}$ & 0,6 & 0.7 & 0.6 & 0.6 & 0.6 & 0.6 & 0.6 & 0.6 & 0.5 & 0.5 & 0.5 & 0.5 & 0.5 & 0.5 & 0.5 \\
\hline 0.0 & 0.0 & 0.0 & 0.0 & 0.2 & 0.0 & 0.0 & 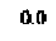 & H:1 & 0.0 & do & a.o & 0.0 & 0.0 & D.0. & 0.0 & 0.8 & 0.0 & 0.0 & 0.0 & 0.0 & 0.1 & 0.0 \\
\hline-2.3 & -32 & 0.2 & -0.6 & -1.1 & -2.3 & -1.8 & 0.2 & -1.9 & -0.8 & +0.5 & -0.6 & -1.0 & -0.7 & -1.3 & -0.6 & -0.1 & -63 & -0.3 & 0.0 & $\$ 1$ & 03 & 0.0 \\
\hline
\end{tabular}

Sources: Bank of telly, Relarione dururale, various issines. 
Table 6. Italy: Expenditures of Subnational Governments

(In percent of total)

\begin{tabular}{|c|c|c|c|c|c|c|c|c|c|c|c|c|c|c|c|c|c|c|c|c|c|c|c|}
\hline & 1976 & $19 \pi$ & 1978 & 1979 & 1980 & 1981 & 1982 & 1983 & 1984 & 1985 & 1986 & 1987 & 1988 & 1989 & 1990 & [99] & 1992 & 1993 & 1994 & 1995 & 1996 & 1997 & 1998 \\
\hline 'l'otal expendikures & 100.0 & 100.0 & 1000 & 100.0 & 100.0 & 100.0 & 1000 & 100.0 & 1000 & 100.0 & 1000 & 1000 & 100.0 & 100.0 & 100.0 & 100.0 & 100.0 & 180,0 & 100.0 & 100,0 & 1000 & 100.0 & 100.0 \\
\hline Clatent expendinares & 79.4 & 78.4 & $B 00$ & $\$ 1.6$ & 78.3 & 77.0 & 77.6 & 20.9 & 79.3 & 79.1 & 79.2 & 80.0 & 803 & 79.8 & 81.1 & 82.0 & 82,9 & 83,7 & 85.0 & 84.4 & 83.9 & 83.0 & $\$ 2.1$ \\
\hline Wages and salaries & 33.8 & 34,0 & 36.2 & 34.8 & 32.3 & 33.6 & 33.1 & 33.1 & 32.4 & 31.1 & 31.4 & 3t. 2 & 31,5 & 30.8 & 31.7 & 32.6 & 32,2 & 32.4 & 34.9 & 35.8 & 34.9 & 35.2 & 33.0 \\
\hline Goods and servicess & 20.6 & 20.6 & 22.3 & 20.7 & 16.8 & 17.4 & 17.5 & 18.3 & $1 \mathrm{~B} .9$ & 18.9 & 19.0 & 18.7 & 18.8 & 19.2 & 19.4 & 20.0 & 20.9 & 21.4 & 21.6 & 22.9 & 23.4 & 230 & 23.1 \\
\hline Transfers to public instilutions & 0.5 & 0.9 & 10 & 10.5 & 10.9 & 0.8 & 0.9 & 1.0 & 0.6 & 1.0 & 0.6 & 0.7 & 04 & 0.6 & 0.3 & 0.2 & 0.2 & 0.3 & 0.3 & 0.3 & 0.2 & 0.2 & 0.7 \\
\hline Social tranefers & 2.5 & 2.9 & 3.1 & 2.8 & 4.2 & 13.5 & $\$ 45$ & 14.8 & 14.5 & 14,6 & 14,3 & 16.3 & 17.1 & 16.9 & 17.7 & 17.5 & 17.4 & 16.7 & 15.3 & 15.9 & 15.8 & 15.7 & 16.2 \\
\hline Production subsidies & 6.3 & 6.7 & 7.8 & 5.2 & 5.9 & 5.0 & 5.5 & 5.7 & 5.5 & 5.3 & 5.5 & 5.2 & 4.7 & $\$ 2$ & 4.6 & 4.3 & 46 & 5.1 & 4.8 & 4.2 & 4,3 & 4.0 & 3.7 \\
\hline Interest payments & 30.4 & 137 & 7.4 & 5.1 & 4.6 & 4.4 & 4.0 & 4.4 & 5.1 & 5.3 & 5.3 & 49 & 4.6 & 4.4 & 4.4 & 4.4 & 4.4 & 4.6 & 4.7 & 4.3 & 4.4 & 4.3 & 3.5 \\
\hline Other surent & 3.5 & 2.6 & 22 & 2.5 & 3.6 & 2.4 & 2.1 & 2.6 & 2.3 & 2.9 & 3.1 & 3.0 & 3.3 & 2.7 & 25 & 3.0 & 3.2 & 3.2 & 3.3 & 1.0 & 0.9 & 0.5 & 1.8 \\
\hline Capital expenditures & 20.5 & 20.6 & 20.0 & 38.4 & 21.7 & 23.0 & 22.4 & 20.1 & 20.7 & 20.9 & 20.8 & 20.0 & 19.7 & 20.2 & 18.9 & 18.0 & 17.1 & 16.3 & 15.0 & 15.6 & 36.1 & 17.0 & 17.9 \\
\hline Gross-ixed invedinnents & 15.8 & 15.2 & 15.3 & 13.9 & 15.1 & 16.7 & 16.6 & 15.3 & 15.9 & 15.9 & 16.1 & 15.8 & 15.7 & 160 & 150 & 14.0 & 13.3 & 12.4 & 11.3 & 11.7 & 12.2 & 13.0 & 13.9 \\
\hline Investretent subsidites & 47 & 5.2 & 4.6 & 4.2 & 53 & 63 & 5.6 & 4.8 & 4.5 & 4.8 & 4.4 & 3.9 & 3.9 & 3.9 & 3.1 & 3.7 & 3.5 & 36 & 3.4 & 3.6 & 3.6 & 3.4 & 37 \\
\hline Other . & 0.1 & 0.2 & 0.1 & 0.3 & 3.4 & 0.0 & 0.0 & 0.1 & 0.4 & 0.2 & 0.2 & 0.2 & 0.2 & 0.3 & $0: 2$ & 0.3 & 0.3 & 0.3 & 0.3 & 6. 3 & 0.3 & 0,6 & 0.3 \\
\hline
\end{tabular}

Sources: Bank of Italy, Relorione Arnuale, various issues. 
Table 7. Italy: Expenditures of Regions, 1997-99 1/

\begin{tabular}{|c|c|c|c|c|c|c|}
\hline & 1997 & 1998 & 1999 & 1997 & 1998 & 1999 \\
\hline & \multicolumn{3}{|c|}{ (In billions of lire) } & \multicolumn{3}{|c|}{ (In percent of total) } \\
\hline Total Expenditures & 164,640 & 173,636 & 181,724 & 100.0 & 100.0 & 100.0 \\
\hline Current expenditures & 138,296 & 146,329 & 152,450 & 84,0 & 84.3 & 83.9 \\
\hline Wages and salaries & 7,051 & 7,539 & 7,619 & 4.3 & 4.3 & 4.2 \\
\hline Goods and services & 4,102 & 4,211 & 4,421 & 2.5 & 2.4 & 2,4 \\
\hline Transfers & 122,976 & 130,572 & 136,717 & 74.7 & 75.2 & 75.2 \\
\hline Health & 100,831 & 106,156 & 110,393 & 61.2 & 61.1 & 60.7 \\
\hline Provinces and municipalities & 5,327 & 8,255 & 8,971 & 3.2 & 4.8 & 4.9 \\
\hline Other public institutions & 2,308 & 2,195 & 2,475 & 1.4 & 1.3 & 1.4 \\
\hline Households & 4,994 & 4,703 & 5,033 & 3.0 & 2.7 & 2.8 \\
\hline Autonomous public agencies & 6,357 & 6,265 & 6,585 & 3.9 & 3.6 & 3.6 \\
\hline Firms & 2,749 & 2,764 & 3,006 & 1.7 & 1.6 & 1.7 \\
\hline Other & 410 & 234 & 254 & 0.2 & 0.1 & 0.1 \\
\hline Interest payments & 2,532 & 2,318 & 1,920 & 1.5 & 1.3 & 1.1 \\
\hline Other current & 1,635 & 1,689 & 1,773 & 1.0 & 1.0 & 1.0 \\
\hline Capital expenditures & 23,978 & 26,033 & 28,018 & 14.6 & 15.0 & 15.4 \\
\hline Fixed investment & 4,567 & 4,622 & 4,751 & 2.8 & 2.7 & 2.6 \\
\hline Capital transfers & 18,045 & 20,143 & 21,814 & 11.0 & 11.6 & 12,0 \\
\hline Health & 2,232 & 3,539 & $3,25]$ & 1.4 & 2.0 & 1.8 \\
\hline Frowinces and municipalities & 4,342 & 4,579 & 5,370 & 2.6 & 2.6 & 3.0 \\
\hline Other public institutions & 2,826 & 2,776 & 3,251 & 1.7 & 1.6 & 1.8 \\
\hline Households & 1,695 & 1,972 & 2,159 & 1.0 & 1.1 & 1.2 \\
\hline Autonomous public agencies & 799 & 839 & 958 & 0.5 & 0.5 & 0.5 \\
\hline Firms & 6,151 & 6,438 & 6,825 & 3.7 & 3.7 & 3.8 \\
\hline Other & 2,232 & 3,539 & 3,251 & 1.4 & 2.0 & 1.8 \\
\hline Other capital & 1,356 & 1.268 & $1,45 \pm$ & 0.8 & 0.7 & 0.8 \\
\hline Finnnoial outlays & 2,366 & 1.274 & 1,256 & 1.4 & 0.7 & 0.7 \\
\hline
\end{tabular}

Sounce: Ministry of the Treasury, Budget, and Ecenomic Planning, Relazione Trimestrale di Cassa.

1/ Datá are on a cash basis. 
Table 8. Italy: The Structure and Growth of Regional Current Health Care Expenditure

\begin{tabular}{|c|c|c|c|c|c|c|c|}
\hline & \multicolumn{5}{|c|}{ Share in Total Current Health Expenditure } & \multirow{2}{*}{\multicolumn{2}{|c|}{$\begin{array}{l}\text { Average Yearly Rate } \\
\text { of Change (nominal) } \\
1993-951995-1997\end{array}$}} \\
\hline & 1993 & 1994 & 1995 & 1996 & 1997 & & \\
\hline Personnel costs & 41.0 & 41.3 & 42.6 & 42.6 & 43.4 & 1.0 & 9.0 \\
\hline Goods and services & 18.8 & 19.7 & 19.5 & 19.2 & 18,1 & 1.0 & 4.1 \\
\hline Pharmaceuticals & 19.0 & 17.5 & 16.9 & 17.4 & 17.5 & -6.8 & 10.0 \\
\hline Contracted private hospital care & 10,8 & 11.1 & 11.1 & 10.8 & 10,9 & 0.4 & 7.2 \\
\hline Contracted specialists & 2.8 & 2.6 & 2.5 & 2.5 & 2.7 & -6.7 & 11.7 \\
\hline Other contracted services & 5.8 & 6.2 & 6.6 & 6.8 & 6.8 & 5.9 & 9.4 \\
\hline Other costs & 1.8 & 1.5 & 0.8 & 0.7 & 0.7 & -35.2 & 1.2 \\
\hline Total costs & 100.0 & 100.0 & 100.0 & 100.0 & 100.0 & -1.0 & 8.1 \\
\hline
\end{tabular}

Source: Corte dei Conti (1999). 
Table 9. Italy: Growth of Real Health Care Expenditure, 1980-97

\begin{tabular}{lccccc} 
& North West & North East & Center & South & Average \\
\hline $\begin{array}{l}\text { Average yearly growth rate (in percent) } \\
\quad \text { Of which attributable to }\end{array}$ & 2.54 & 2.21 & 2.03 & 2.41 & 2.32 \\
$\quad$ Population growth & -0.10 & 0.06 & 0.13 & 0.26 & 0.10 \\
$\quad$ Aging & 0.37 & 0.40 & 0.42 & 0.35 & 0.38 \\
$\quad$ Other factors & 2.26 & 1.74 & 1.48 & 1.79 & 1.84 \\
\hline
\end{tabular}

Source: Fund staff calculations based on data from CTSP (1999). 


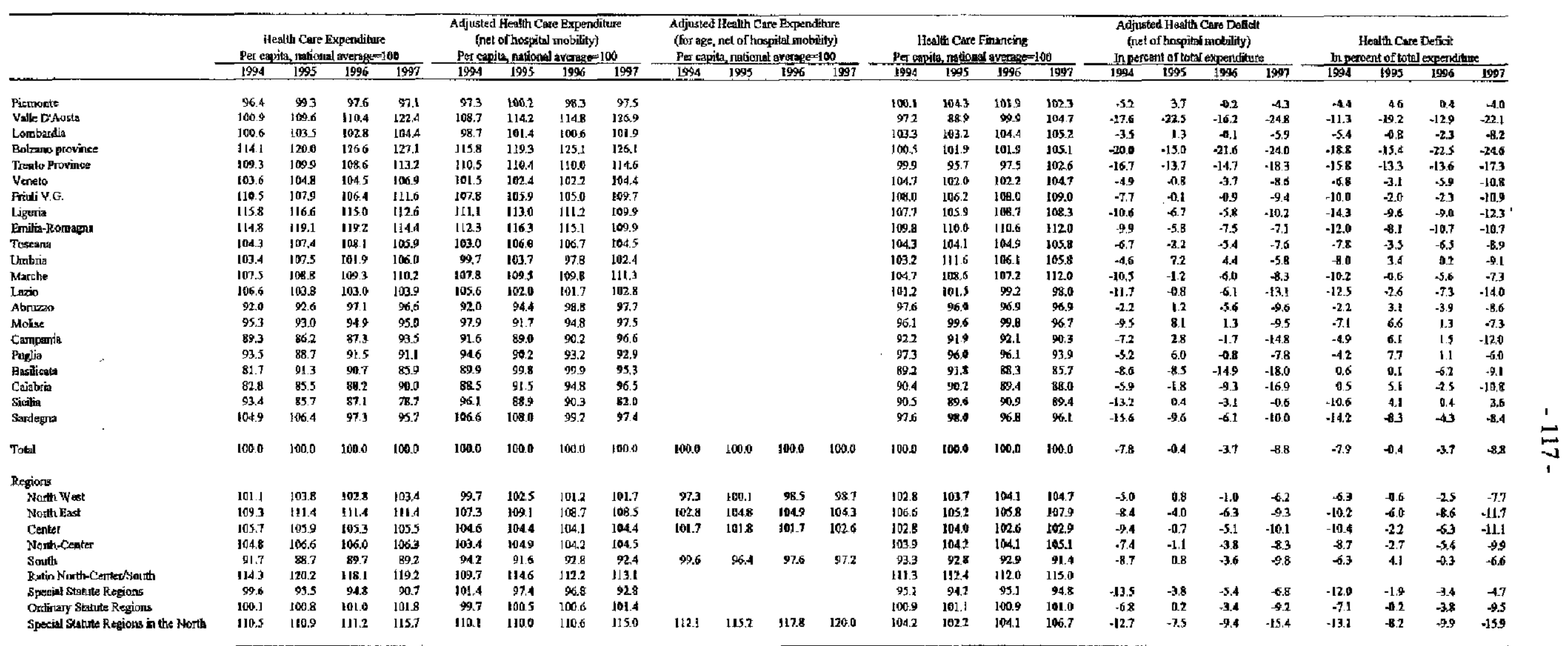

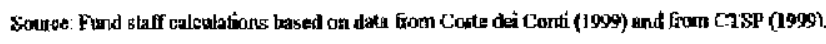


Table 11. Italy: Structure of Regional Health Care Expenditure in 1996

\begin{tabular}{lrrrrr}
\hline & North West & North East & Center & South & Average \\
\hline Total directly managed services & 61.1 & 65.0 & 57.7 & 55.9 & 59.4 \\
$\quad$ Of which & & & & & \\
$\quad$ Personnel costs & 69.8 & 68.3 & 72.5 & 77.1 & 72.3 \\
$\quad$ Goods and services & 30.2 & 31.7 & 27.5 & 22.9 & 27.7 \\
Pharmacentical & 17.2 & 14.2 & 17.1 & 20.2 & 17.6 \\
Contracted private hospital specialist services & 12.8 & 8.7 & 16.6 & 15.1 & 13.6 \\
Other contracied services & 5.2 & 8.5 & 6.1 & 6.6 & 6.5 \\
Other costs & 3.7 & 3.6 & 2.5 & 2.2 & 2.9 \\
& & & & & \\
Total & 100.0 & 100.0 & 100.0 & 100.0 & 100.0 \\
\hline
\end{tabular}

Source: CTSP (1999). 
Table 12. Italy: Sources of Health Care Finance, 1993-97

(Total Actual Expenditure $=100$ )

\begin{tabular}{lrrrrr}
\hline & 1993 & 1994 & 1995 & 1996 & 1997 \\
\hline Social security contributions & & & & & \\
Budget (National Heaitti Fund) & 42.0 & 46.2 & 49.2 & 49.3 & 48.2 \\
Other sources & 42.7 & 38.0 & 40.0 & 37.9 & 33.3 \\
Of which & 8.0 & 8.2 & 9.9 & 10.2 & 10.6 \\
$\quad$ Coitsurance & & & & & \\
$\quad$ Self-finance of local health units & 5.7 & 3.8 & 4.3 & 4.0 & 3.7 \\
$\quad$ Special statute regions contribution & 0.0 & 1.7 & 2.3 & 2.0 & 1.9 \\
Total finance & 2.3 & 2.7 & 3.3 & 4.2 & 5.0 \\
Total actual expenditure & 92.7 & 92.4 & 99.1 & 97.4 & 92.1 \\
Deficit. & 100.0 & 100.0 & 100.0 & 100.0 & 100.0 \\
& -7.3 & -7.6 & -0.9 & -2.6 & -7.9 \\
\hline
\end{tabular}

Source: CTSP (1999). 
Table 13. Italy: Own Revenues of Ordinary Statute Regions

\begin{tabular}{|c|c|c|c|c|c|c|c|c|}
\hline & \multicolumn{2}{|c|}{1995} & \multicolumn{2}{|c|}{1996} & \multicolumn{2}{|c|}{1997} & \multicolumn{2}{|c|}{1998} \\
\hline & $\begin{array}{l}\text { Share in } \\
\text { Total Own } \\
\text { Revenue }\end{array}$ & $\begin{array}{c}\text { Share in } \\
\text { GDP }\end{array}$ & $\begin{array}{c}\text { Share in } \\
\text { Total Own } \\
\text { Revenue }\end{array}$ & $\begin{array}{c}\text { Share in } \\
\text { GDP }\end{array}$ & $\begin{array}{l}\text { Shate int } \\
\text { Total Own } \\
\text { Revemue }\end{array}$ & $\begin{array}{l}\text { Share in } \\
\text { GDP }\end{array}$ & $\begin{array}{l}\text { Share in } \\
\text { Total Own } \\
\text { Revenue }\end{array}$ & $\begin{array}{l}\text { Share in } \\
\text { GDP }\end{array}$ \\
\hline Regional business tax (IRAP) & & & & & & & 72.8 & 2.2 \\
\hline Gasoline excise & & & 49.3 & 0.3 & 50.3 & 0.4 & 8.0 & 0.2 \\
\hline Surcharge on natural gas (ARISGAM) & 12.0 & 0.0 & 6.5 & 0.0 & 7.2 & 0.1 & 1.5 & 0.0 \\
\hline Tax on regional concessions & 2.8 & 0.0 & 1.5 & 0.0 & 1.7 & 0.0 & 0.4 & 0.0 \\
\hline Total & 100.0 & 0.4 & 100.0 & 0.7 & 100.0 & 0.7 & 100.0 & 3.1 \\
\hline
\end{tabular}

Source: Fund staff calculations besed on data received from the authorities. 


\begin{tabular}{|c|c|c|c|c|c|c|c|c|c|c|c|}
\hline & Tax Type & $\begin{array}{l}\text { Intro- } \\
\text { duced }\end{array}$ & Legislution & Tax Base & $\begin{array}{l}\text { Tax Rate/Rate of } \\
\text { Sharing }\end{array}$ & Who Sets the Tax Rate & $\begin{array}{c}\text { Who defines the } \\
\text { tax base }\end{array}$ & Earmarking & $\begin{array}{c}\text { Legislation } \\
\text { Defining } \\
\text { Distribution } \\
\text { Rule }\end{array}$ & Thistribition.Rule & $\begin{array}{l}\text { Tax Adminis- } \\
\text { tration }\end{array}$ \\
\hline \multicolumn{12}{|l|}{ Tares } \\
\hline $\begin{array}{l}\text { Regionat tax on business } \\
\text { activity } 1 /\end{array}$ & Own tax & 1998 & $\begin{array}{l}1998 \text { Budget } \\
\text { Law }\end{array}$ & $\begin{array}{l}\text { Value added, } \\
\text { net of depre- } \\
\text { ciation, } \\
\text { inchuding } \\
\text { interest paid }\end{array}$ & $\begin{array}{l}4,75 \% \text { special rates } \\
\text { for agriculture. } \\
\text { banking and } \\
\text { insurance which will } \\
\text { be phased out }\end{array}$ & $\begin{array}{l}\text { from } 2001 \text { regional } \\
\text { governments within a } \\
\text { rapge deteranined by } \\
\text { national legistation }\end{array}$ & $\begin{array}{l}\text { Tax base is } \\
\text { defined in } \\
\text { national } \\
\text { legistation } \\
\text { introdueing tax }\end{array}$ & & & & $\begin{array}{l}\text { Central } \\
\text { government, based } \\
\text { on contractual } \\
\text { agreement with } \\
\text { ach region }\end{array}$ \\
\hline $\begin{array}{l}\text { Regional personal income } \\
\text { tax } 2 /\end{array}$ & $\begin{array}{l}\text { Over- } \\
\text { lapping tax }\end{array}$ & 1998 & $\begin{array}{l}1998 \text { Budget } \\
\text { Law }\end{array}$ & $\begin{array}{l}\text { Same as } \\
\text { national } \\
\text { personal } \\
\text { income thx }\end{array}$ & $\begin{array}{l}\text { Until } 2001 \text { between } \\
\text { 0.5-1\%, from } 2001 \\
\text { between } 0.9-1.4 \%\end{array}$ & $\begin{array}{l}\text { regional governments } \\
\text { within a range } \\
\text { delesmied by legislative } \\
\text { decres }\end{array}$ & $\begin{array}{l}\text { Tax bast is } \\
\text { defined in } \\
\text { legeslation } \\
\text { istroducing tax }\end{array}$ & & & & $\begin{array}{l}\text { Central } \\
\text { govemuent, as } \\
\text { stipulated int } \\
\text { national } \\
\text { legisiation }\end{array}$ \\
\hline Excise on gasoline & Shared tax & 1995 & $\begin{array}{l}1995 \text { Law } \\
\text { No. } 549\end{array}$ & Excise tax & $\begin{array}{l}\text { until } 2001 \text {, Lit } 242 \text {, } \\
\text { fram } 2001 \text { lit } 250\end{array}$ & $\begin{array}{l}\text { Central government, } \\
\text { rogional governments } \\
\text { can increase it by op to } \\
\text { Lit } 50\end{array}$ & & & & & $\begin{array}{l}\text { Central } \\
\text { government }\end{array}$ \\
\hline $\begin{array}{l}\text { Surcharge tax on matural gas } \\
\text { consumption } 3 /\end{array}$ & $\begin{array}{l}\text { Over- } \\
\text { lapping tax }\end{array}$ & 1990 & $\begin{array}{l}1990 \text { Law } \\
\text { No. } 158\end{array}$ & & & & & & & & $\begin{array}{l}\text { Regional } \\
\text { govertiments }\end{array}$ \\
\hline Regional molorvethicle tax & Own tax & 1992 & & $\begin{array}{l}\text { Engine perfor- } \\
\text { mance of motor } \\
\text { vehicle }\end{array}$ & Lit $5,000 / \mathrm{Kw}$ & $\begin{array}{l}\text { Central government, } \\
\text { regional governments } \\
\text { can increase the rate by } \\
\text { up to } 10 \%\end{array}$ & & & & & $\begin{array}{l}\text { Regional } \\
\text { goveruments }\end{array}$ \\
\hline Tax on regional conoessions $4 /$ & Owntax & & & & & & & & & & $\begin{array}{l}\text { Regional } \\
\text { governments }\end{array}$ \\
\hline VAT & Shared tox & $200 \mathrm{I}$ & $\begin{array}{l}\text { Arlicle } 10 \text { of } \\
\text { Law No } 133 \\
1999\end{array}$ & VAT & $\begin{array}{l}25.7 \% \text { of tolal VAT } \\
\text { revemue }\end{array}$ & $\begin{array}{l}\text { Detemined by national } \\
\text { legislation }\end{array}$ & & $\begin{array}{l}\text { Fully } \\
\text { earmarked to } \\
\text { National } \\
\text { Equilization } \\
\text { Fund }\end{array}$ & & & $\begin{array}{l}\text { Central } \\
\text { goverrmment }\end{array}$ \\
\hline \multicolumn{12}{|l|}{ Transfers: } \\
\hline Equalization Fund & & $2(t) 1$ & $\begin{array}{l}\text { Article } 10 \text { of } \\
\text { Eaw No } 133 \\
1999\end{array}$ & & & & & & $\begin{array}{l}\text { Legislative } \\
\text { gowemment } \\
\text { deures }\end{array}$ & Formula-based 5 & $\begin{array}{l}\text { Central } \\
\text { goverament }\end{array}$ \\
\hline
\end{tabular}

1/IRAP-imposta regionale sulle attivita produttive.

2/ Addizionale segionale JRPEF.

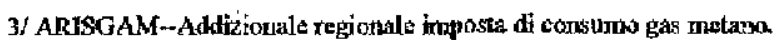

4/ Tasse sulle concessiout regionali.

5/ Taking inlo account population, relatjue size of potendial tax base, health care meeds of population, relative standardized cost of providing nonhelath care public services 
Table 15. Italy: Structure of Tax Revenues in 1998

\begin{tabular}{|c|c|c|c|c|c|}
\hline & $\mathbb{R A P}$ & $\begin{array}{l}\text { Gasoline } \\
\text { Excise }\end{array}$ & $\begin{array}{c}\text { Regional } \\
\text { Income } \\
\text { Tax }\end{array}$ & $\begin{array}{l}\text { Vehicle } \\
\text { Tax }\end{array}$ & Total \\
\hline Piemonte & 75.2 & 6.7 & 6.8 & 11.3 & 100.0 \\
\hline Lombardia & 78.0 & 6.0 & 6.2 & 9.9 & 100.0 \\
\hline Veneto & 74.0 & 7.7 & 6.2 & 12.1 & 100.0 \\
\hline Liguria & 71.1 & 8.8 & 8.2 & 11.9 & 100.0 \\
\hline Emilia-Romagna & 74.6 & 7.6 & 6.5 & 11.4 & 100.0 \\
\hline Toscana & 73.0 & 8.3 & 6.6 & 12.1 & 100.0 \\
\hline Marche & 71.7 & 8.9 & 6.3 & 13.1 & 100.0 \\
\hline Umbria & 67.2 & 9.9 & 6.8 & 16.1 & 100.0 \\
\hline Lazio & 76,5 & 7,5 & 5.9 & I0.1 & 100.0 \\
\hline Abruzzo & 67.5 & 10.3 & 6.6 & 15.6 & 100.0 \\
\hline Molise & 67.7 & 9.3 & 7.0 & 160 & 100.0 \\
\hline Camparia & 68.6 & 9.5 & 7.3 & 14,6 & 100,0 \\
\hline Basilicata & 68.3 & 8.2 & 6.6 & 16.9 & 100.0 \\
\hline Puglia & 63.8 & 12.1 & 7.2 & 16.9 & 100.0 \\
\hline Calabria & 63.9 & 12.4 & 7.1 & 16.7 & 100.0 \\
\hline Average & 74.0 & 7.7 & 6.5 & 11.8 & 100,0 \\
\hline North-Center & 75.4 & 7.2 & 6.4 & 11.1 & 100.0 \\
\hline South & 664 & 10.7 & 7.1 & 15.8 & 100.0 \\
\hline
\end{tabular}

Source: Fund staff calculations based on data in Bordignon and Emiliani (1999). 
Table 16. Italy: Per Capita Revenues of Regions in 1998

(Average of Regions $=100$ )

\begin{tabular}{|c|c|c|c|c|c|c|c|}
\hline & $\overline{\mathbb{R A P}}$ & $\begin{array}{l}\text { Gasoline } \\
\text { Excise }\end{array}$ & $\begin{array}{c}\text { Regional } \\
\text { Income } \\
\text { Tax }\end{array}$ & $\begin{array}{l}\text { Vehicle } \\
\text { Tax }\end{array}$ & $\begin{array}{c}\text { Total Own } \\
\text { Tax } \\
\text { Revenue }\end{array}$ & Transfers & $\begin{array}{c}\text { Total } \\
\text { Revenuse }\end{array}$ \\
\hline Piemonte & 114.7 & 97.9 & 118.2 & 108.3 & 112.9 & 79,8 & 99.5 \\
\hline Lombardia & 144.7 & 105.8 & 130.0 & 115.1 & 137,2 & 45.9 & 100.3 \\
\hline Veneto & 117.9 & 117.0 & 112.4 & 120.5 & 117.8 & 75.3 & 100.6 \\
\hline Liguria & 88.3 & 105.1 & 116.2 & 92.2 & 91.9 & 133.4 & 108,7 \\
\hline Emilia-Romagna & 129.0 & 125,3 & 127.3 & 123.3 & 128,0 & 77.1 & 107.4 \\
\hline Toscana & 104.2 & 112.8 & 107.9 & 108.4 & 105.6 & 98.0 & 102.5 \\
\hline Marche & 95.0 & 112.6 & 95.7 & 108.4 & 98.0 & 93.0 & 96.0 \\
\hline Umbria & 80.8 & 113.5 & 92.9 & 121.3 & 88.9 & 135.3 & 107.7 \\
\hline Lazio & 118.3 & 110.6 & 104.4 & 97.8 & 114.4 & 7.1 & 96.9 \\
\hline Abruzzo & 68.4 & 100.2 & 76.6 & 98.8 & 75.0 & 139.7 & 101.1 \\
\hline Molise & 55.8 & 73.6 & 65.7 & 82.3 & 60.9 & 186.5 & 111.7 \\
\hline Campania & 47.2 & 62.5 & 56.9 & 63.0 & 50.9 & 156.2 & 93.5 \\
\hline Basilicata & 52.0 & 59.9 & 57.4 & 80.5 & 56.3 & 183.1 & 107.6 \\
\hline Puglia & 47.6 & 86,3 & 61.4 & 79.0 & 55.2 & 156.4 & 96.1 \\
\hline Calabria & 40.6 & 75.4 & 51.3 & 66.3 & 47,0 & 183.6 & 102.2 \\
\hline Total & 100.0 & 100.0 & 100.0 & 100.0 & 100.0 & 100.0 & 100.0 \\
\hline North-Center & 121.2 & 110,4 & 116.8 & 111.3 & 118.9 & 75.0 & 101.2 \\
\hline South & 48.7 & 74.8 & 59.4 & 72.5 & $\$ 4.2$ & 160.6 & 97.2 \\
\hline Ratio North-Center/South & 249.0 & 147.5 & 196.7 & 153.5 & 219.3 & 46.7 & 104.0 \\
\hline
\end{tabular}

Source: Fund staff calculations based on data in Bordignon and Emiliani (1999). 
Figure 1. Italy: Public Expenditures, 1977-99

(In percent of GDP)

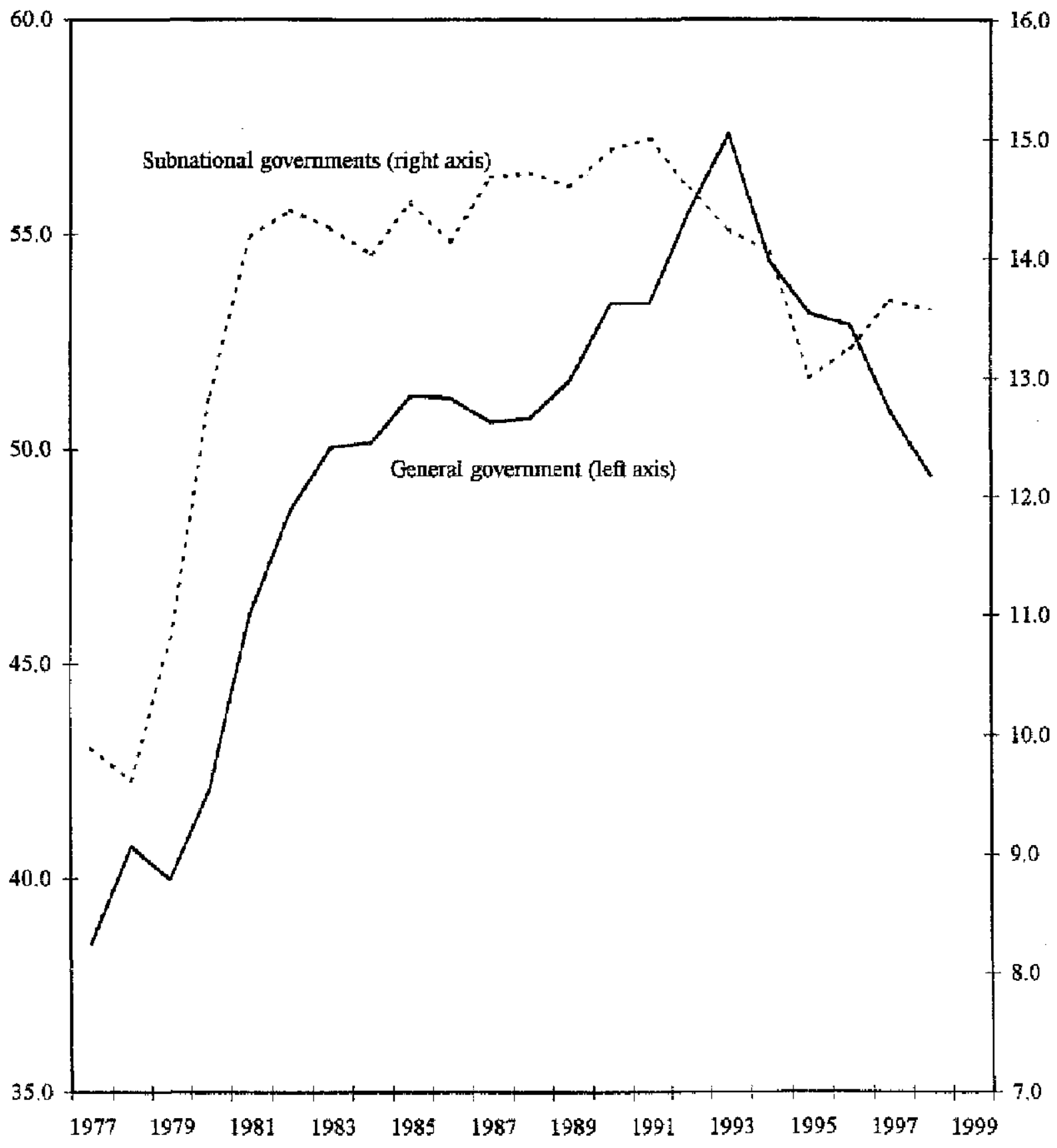

Source: Fund staff calculations. 
Figure 2. Italy: Composition of General Government Defictt, 1977-99 (In percent of GDP)

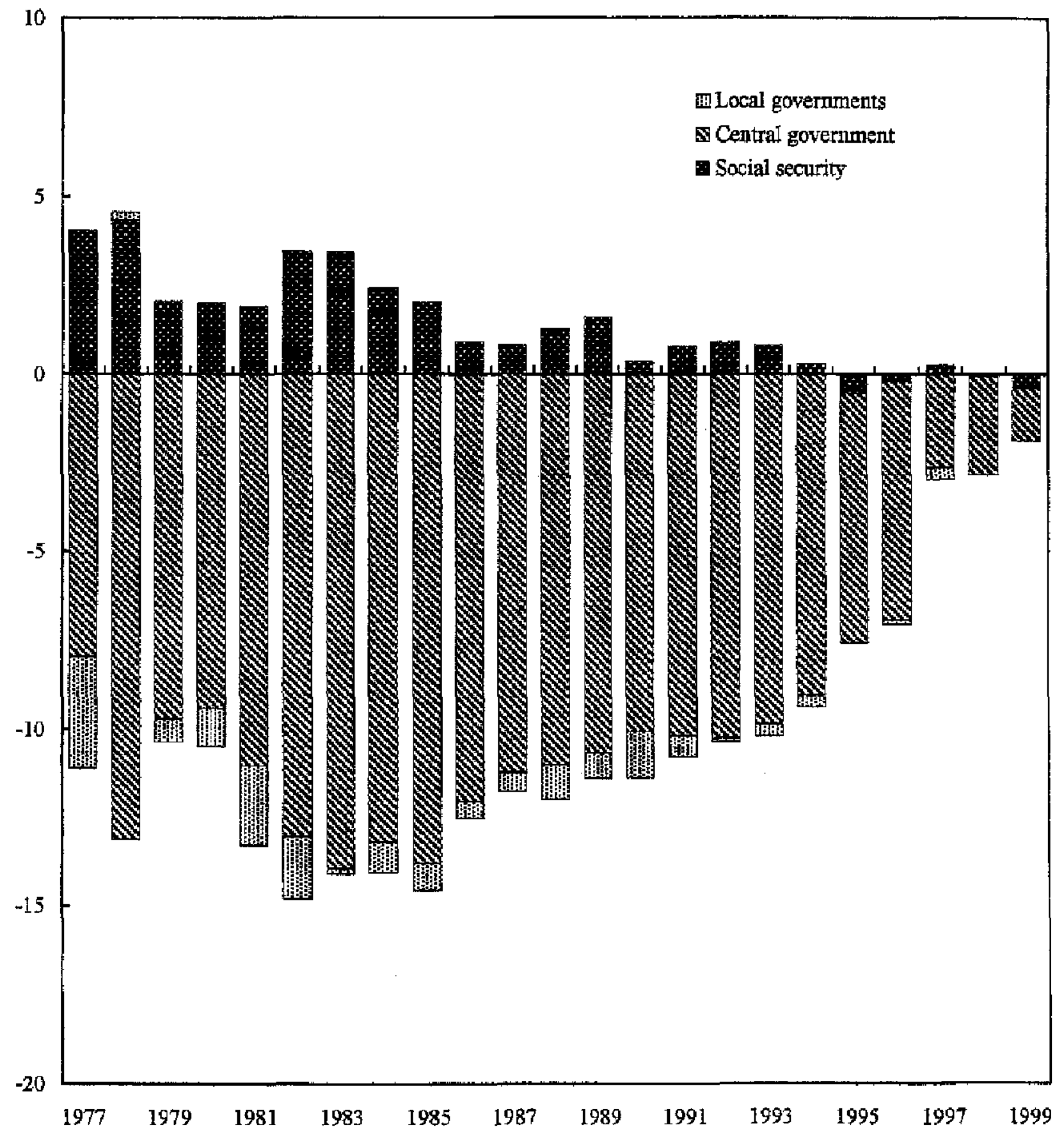

Source: Fund staff calculations. 
Figure 3. Italy: The Share of Health Care Expenditure in GDP, 1960-97

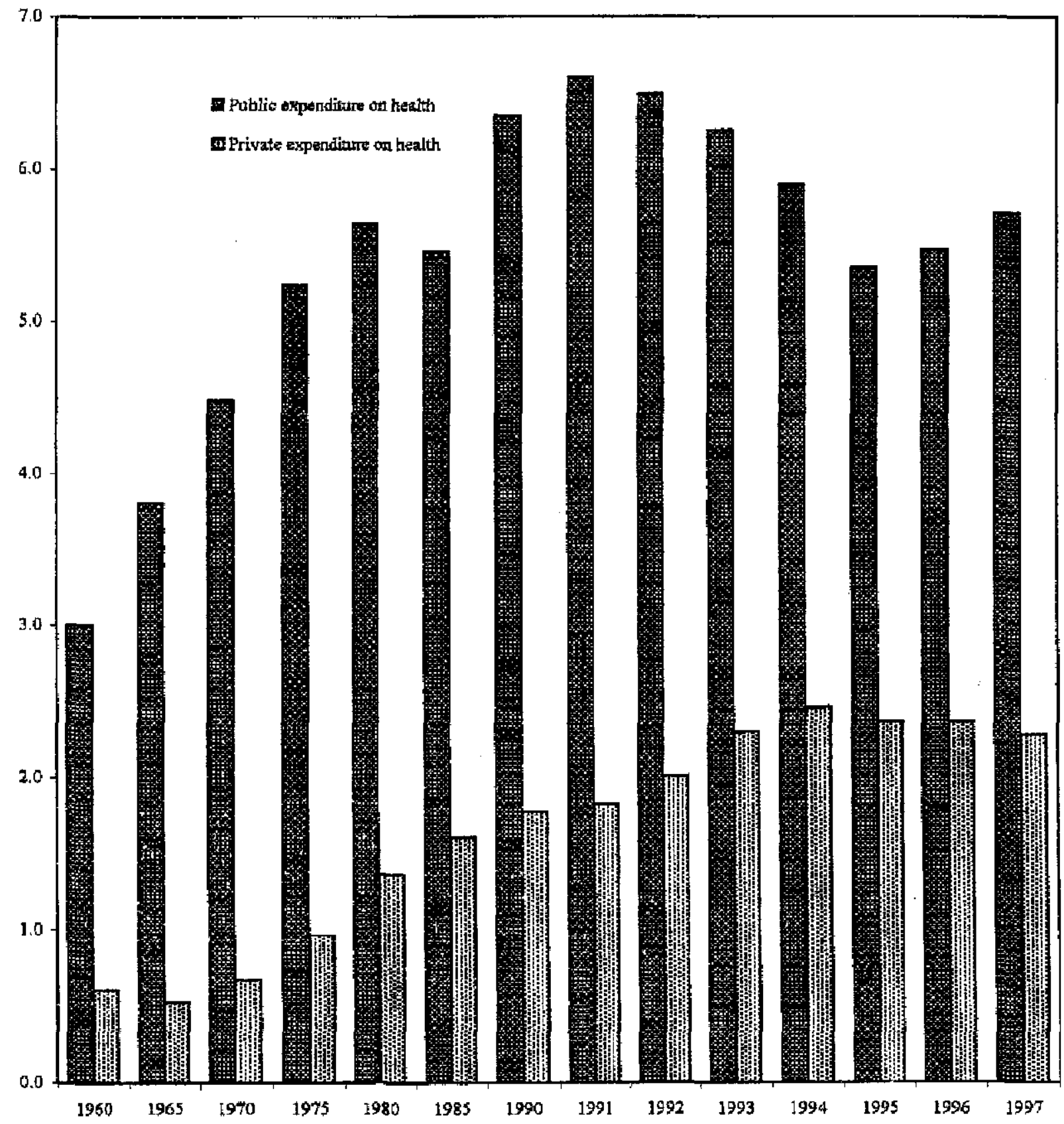

Source: Fund staff calculations. 
Figure 4, Italy: The Share of Total Health Care Expenditure in GDP, 1970-97

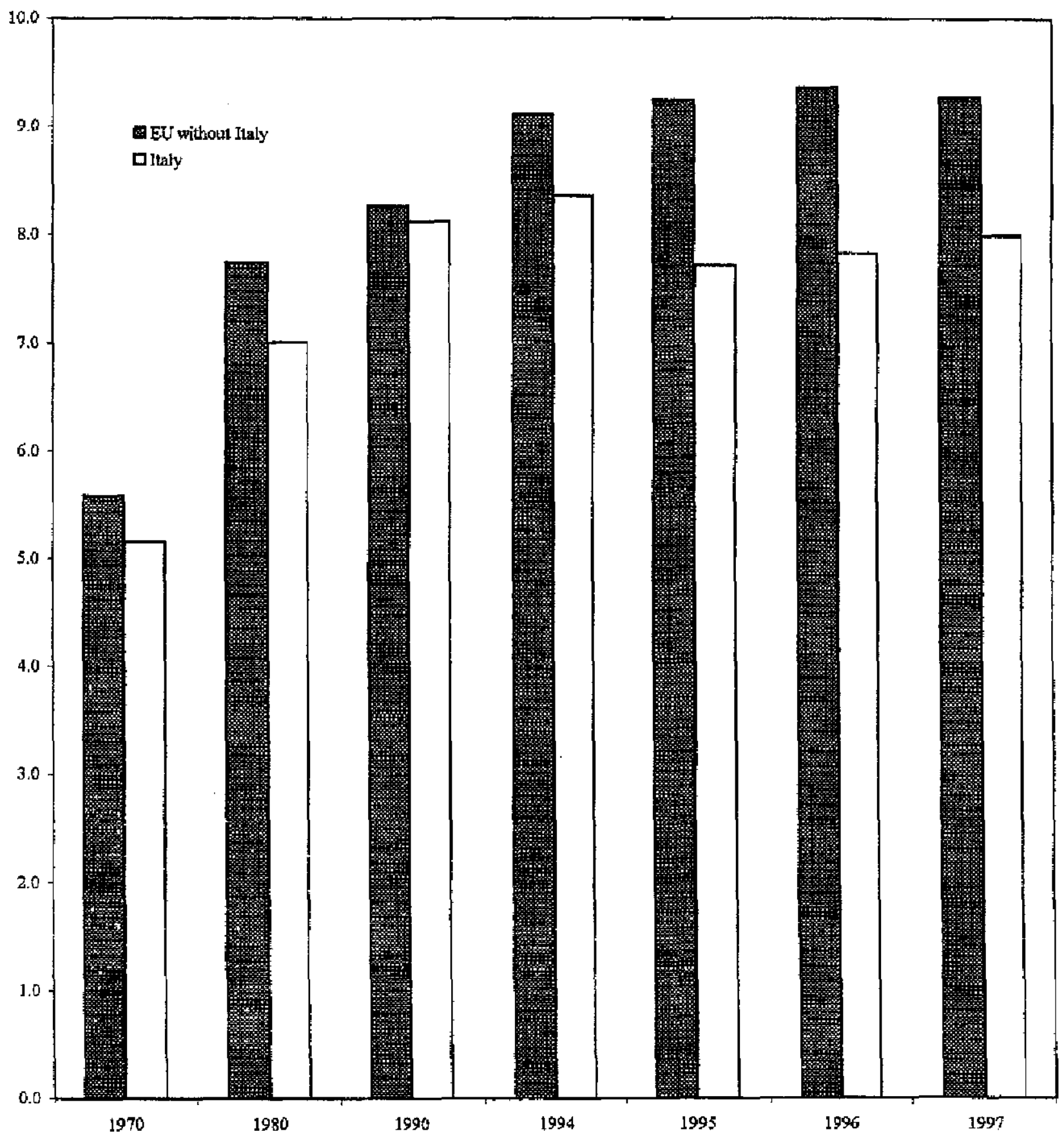

Source: Fund staff calculations. 
Figure 5. Italy: Average Arrual Growth Rates of Real Current Health Care Expenditure, 1961-95

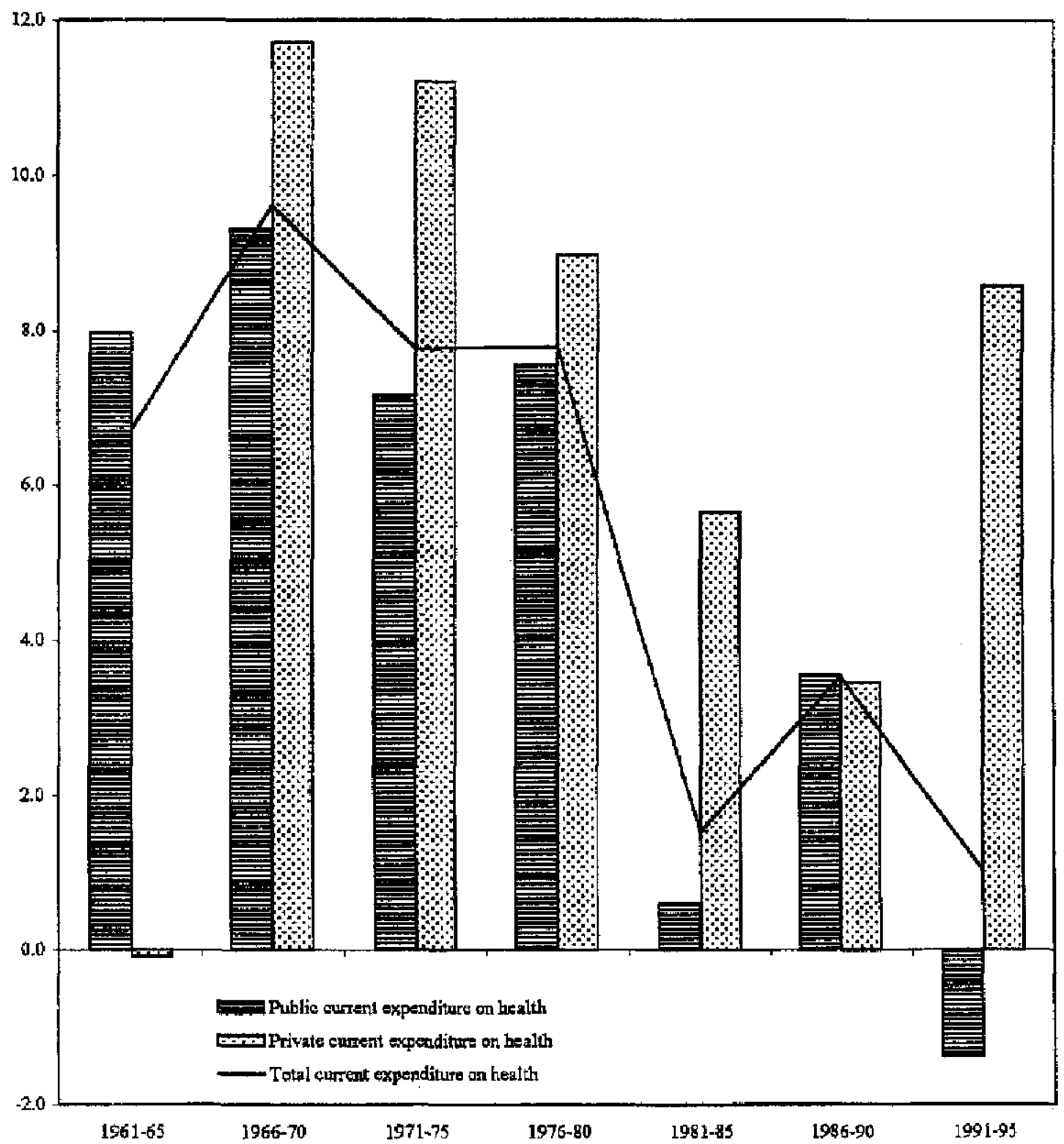

Source: Fund staff calculations. 
Figure 6. Italy: Health Care Expenditure and Aging, 1970-97

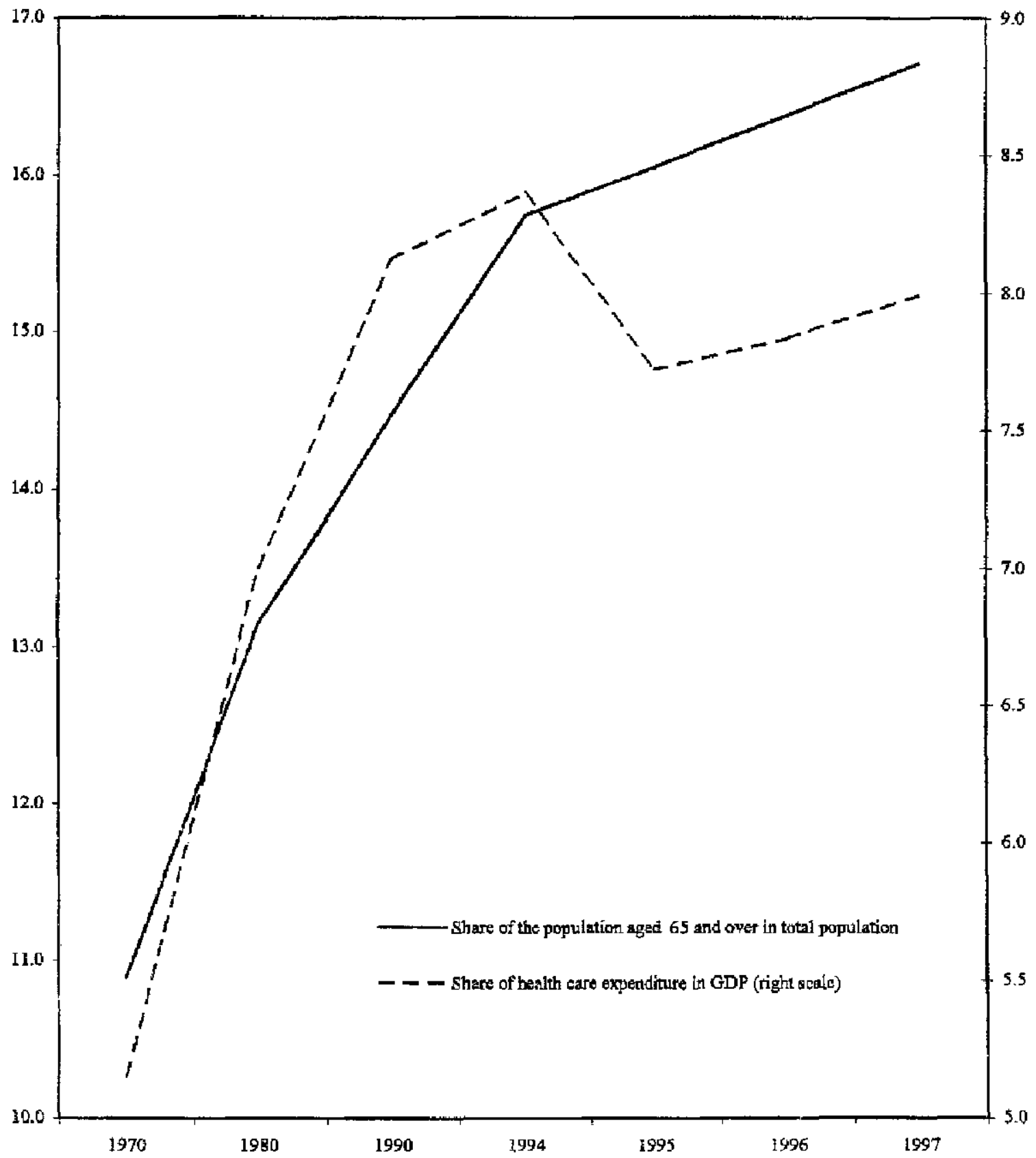

Source: Fund staff calculations. 
Figure 7. Italy: Health Care Expenditure and Aging in the Rest of the European Union, 1970-97

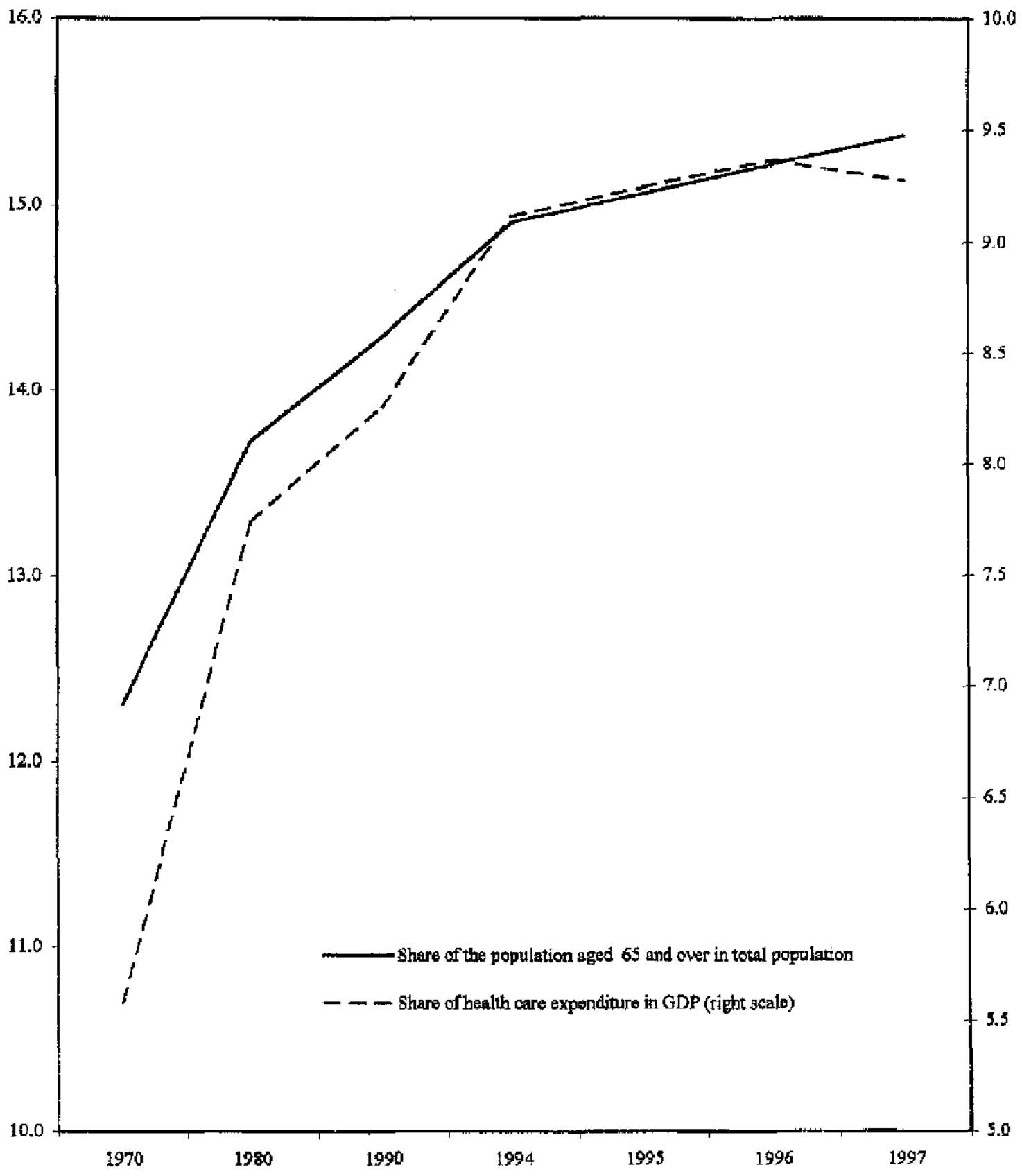

Source: Fund staff calculations. 
Figure 8. Italy: Inequality Among Regions in Income and Health Care Expenditure, 1997

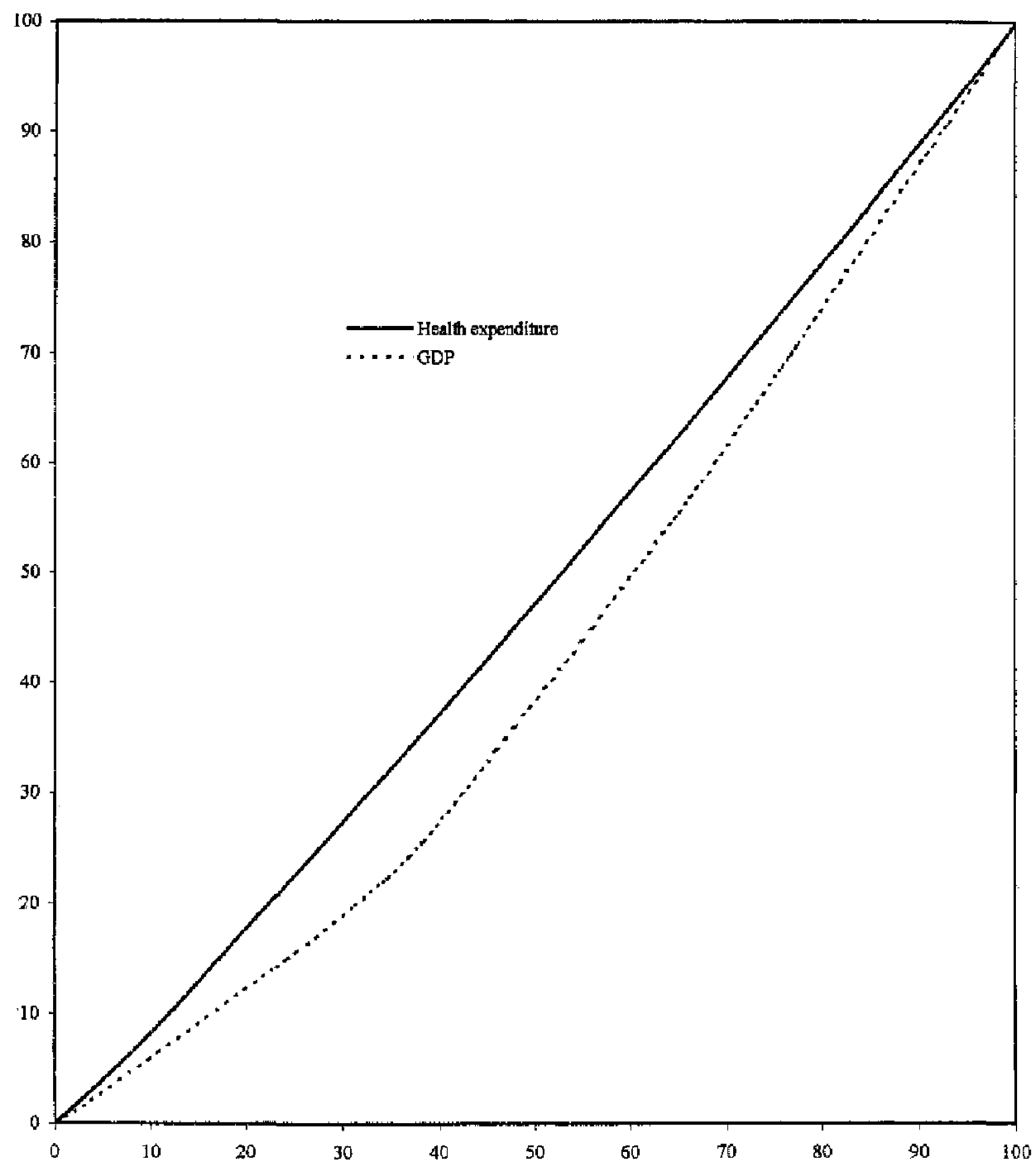

Source; Fund staff calculations. 
Figure 9. Italy; Interregional Inequality in Regional Tax Bases and Total Regional Budget Revenue, 1998

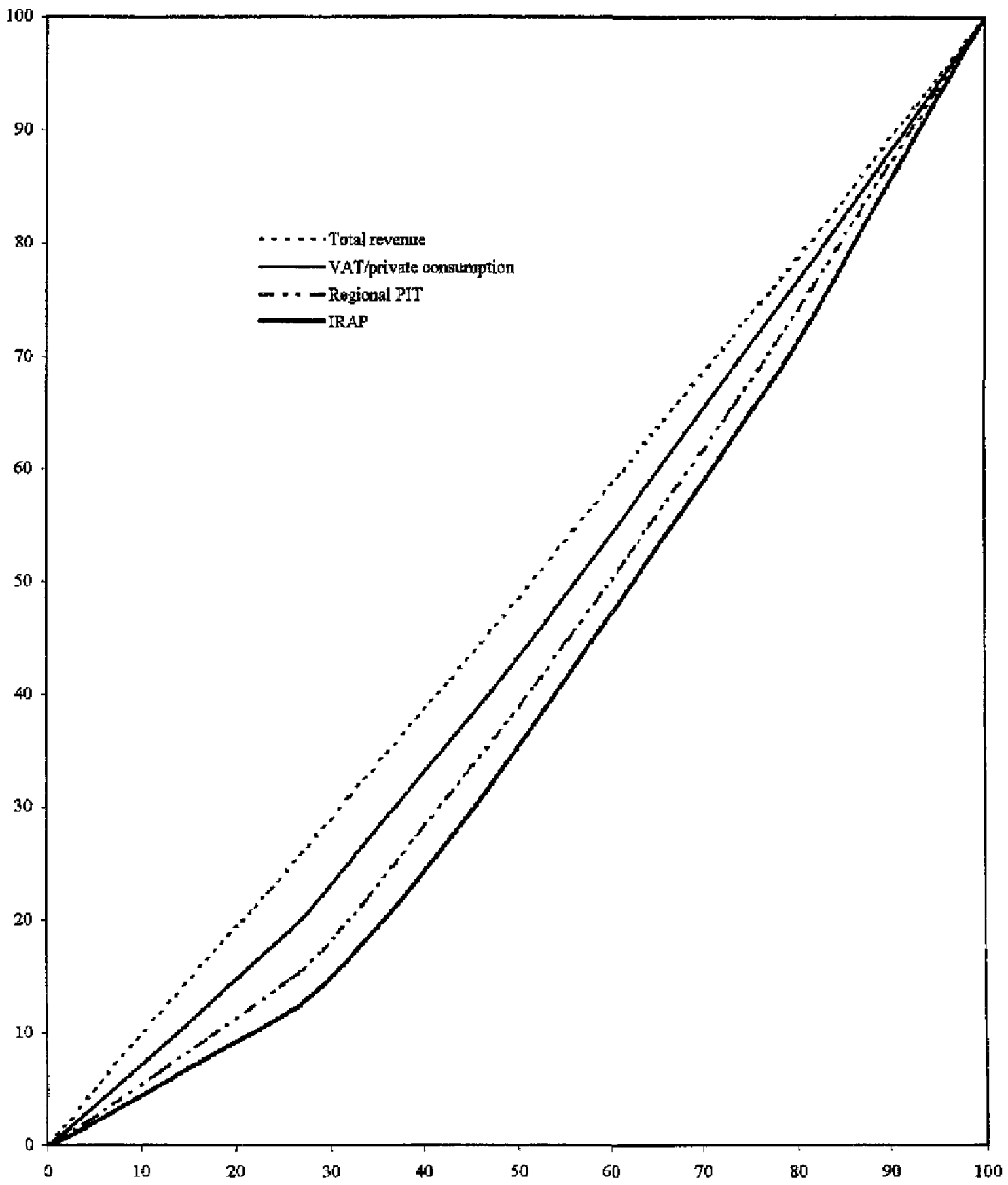

Sol:rce: Fund staff calculations. 
Figure 10. Italy: Projected Revenues of Regions in the First Year of the Transition

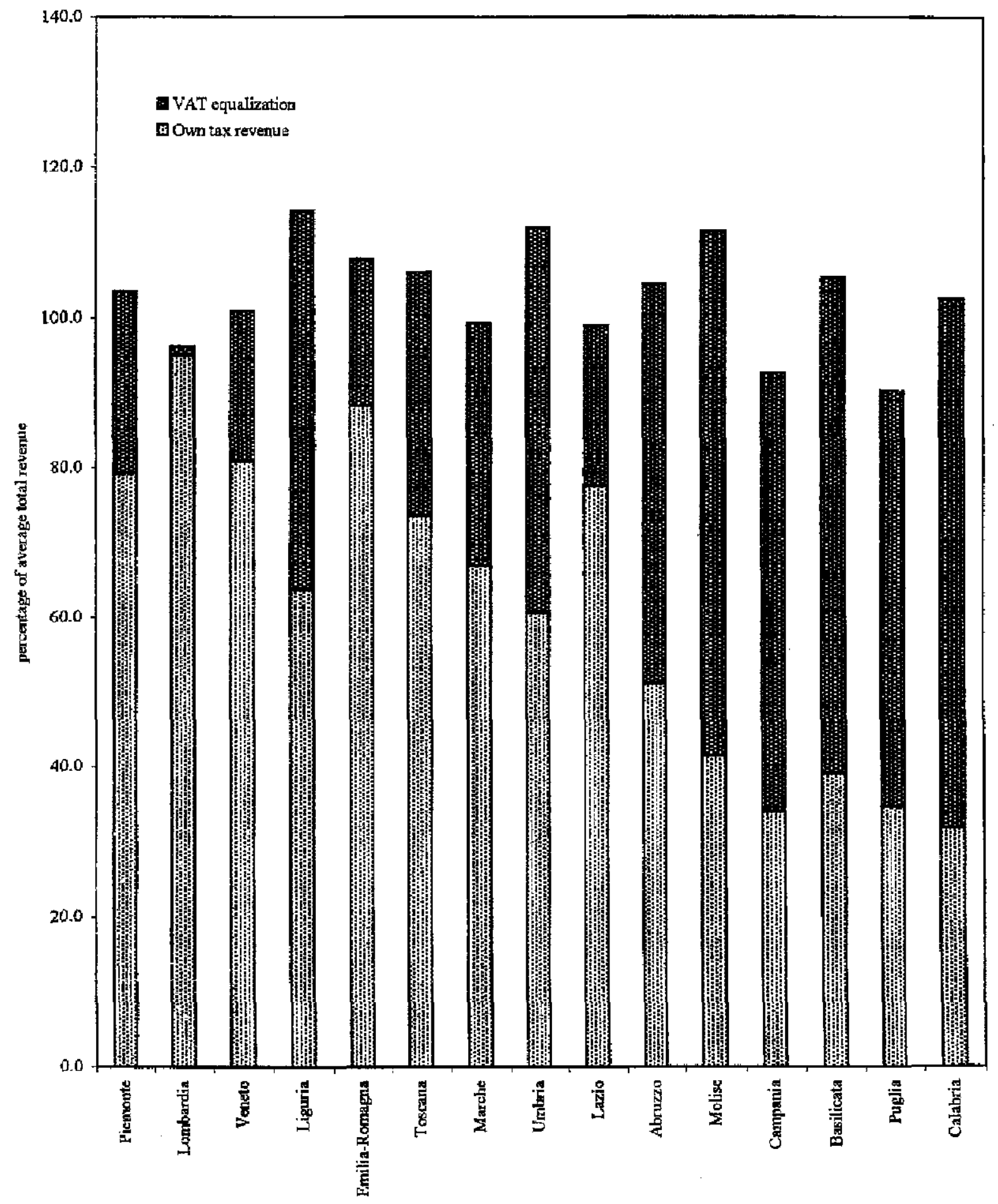

Source: Fund staff calculations. 
Figure 11. Italy: Interregional Inequality in Income and Bidget Revenue, 1998

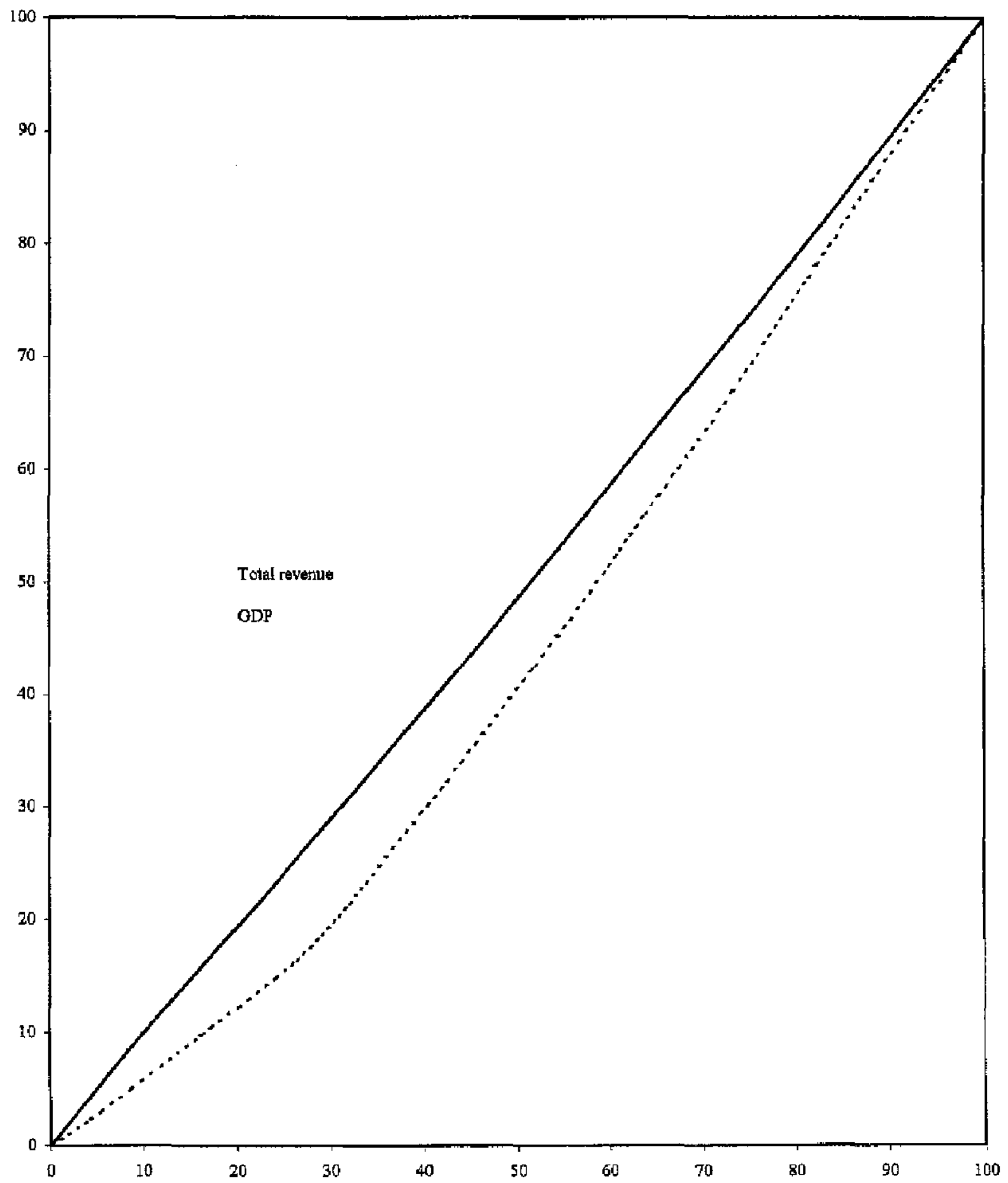

Source: Fund staff calculations. 
Figure 12. Italy: Capacity to Raise Additional Revenue from Regional Taxes by Increasing Tax Rate

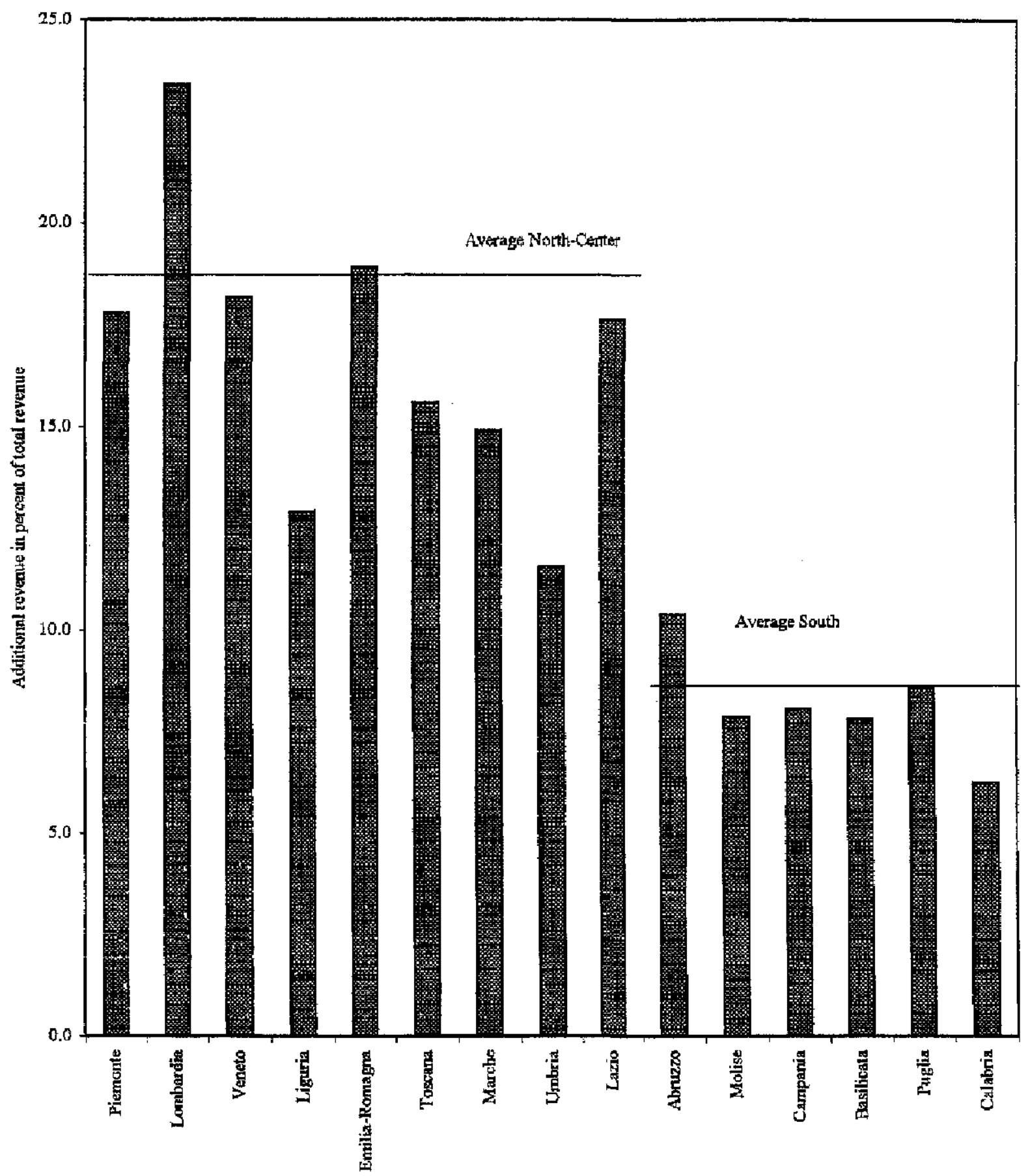

Source: Fund staff calculations. 
Figure 13. Italy: Projected Total Revenues of Regions in the First Year of Transition.

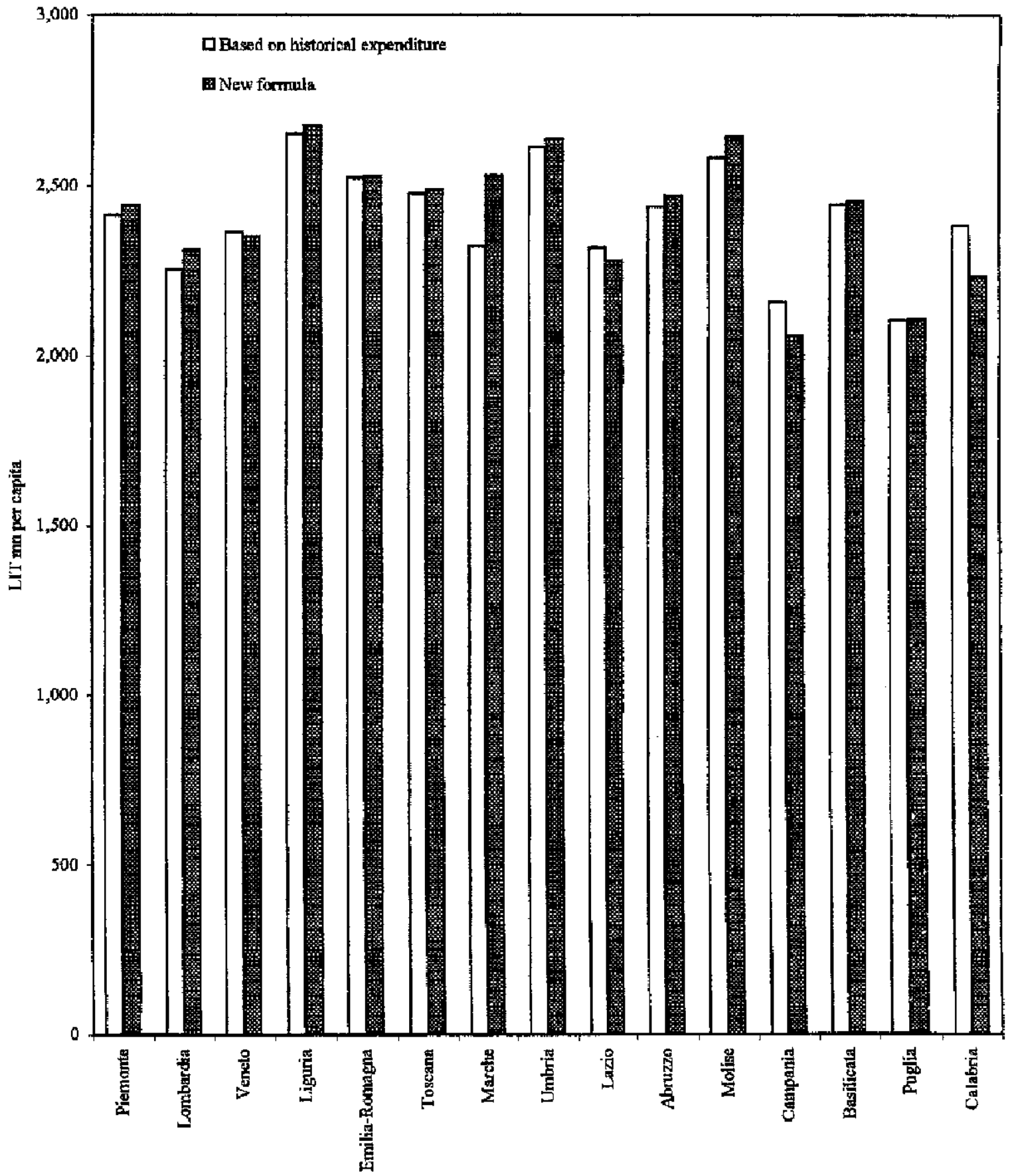

Source: Fund staff calculations. 


\section{The Matn Regional TaXes}

188. IRAP (imposta regionale sulle attivita produttive) is a regional tax on productive activities which was introduced in 1998 to replace a municipal business tax (ICIAP), a tax on dividend payments, a net worth tax, and a payroll health care contribution. It is levied on companies, partnerships and individuals carrying out business activity. Unlike the previously existing health care contributions, it is not deductible from the taxable base for the national corporate income tax (IRPEG). The tax base of IRAP is the value added (net of depreciation) produced in a region. In case a taxpayer carries out business activities in several regions, the value added is allocated according to the labor cost in each region. There are special rules for financial institutions. The uniform tax rate is 4.25 percent. Banks and insurance companies pay a higher rate, while agricultural businesses pay a preferential rate. Both nonstandard rates will be phased out gradually. Starting in 2001 regions will have the right to increase the rate of IRAP by up to 1 percentage point and also to establish differentiated tax rates for certain types of businesses.

189. The 1997 tax reform introduced a regional personal income tax (addizionale regionale $I R P E F$ ). The regional personal income tax (regional PIT) taxes the same base as the national progressive personal income tax (IRPEF), but at a flat rate which the regional governments could originally set between 0.5 and 0.9 percent. To create the room for the regional income tax, national income tax rates were reduced by 0.5 percentage point. The recent reform has increased the range to 0.9 to 1.4 percent, and reduced national rates accordingly (by 0.4 percentage points). The law gives the right to collect the regional income tax to the central government, which then transfers it to the regions, but tax payment withheld at source is directly transferred to the region. The regional PIT is not deductible under the national income tax.

190. Since 1995, the revenue from excise taxes on gasoline is shared between the central government and the regions. The framework law passed in 1999 allows for up to Lit 450 per liter to be allocated to the regions, but the government legislation implementing the law allocated only Lit 250 , Lit 8 more than previously. Regions have the right to increase excise tax on gasoline by up to Lit 50 per liter.

191. Regions levy a tax on motor vehicles registered and operated by resident companies and individuals (Tassa regionale di circolazione). The tax base is the engine performance of the car and the rate set by the central government can be increased by up to 10 percent by the regions. 


\section{REFERENCES}

Alesina, A., S. Danninger, and M. Rostagno, 1999, "Redistribution Through Public Employment: The Case of Italy," IMF Working Paper 99/177, (Washington: International Monetary Fund).

Balassone, F. and D. Franco, 1999, "Fiscal Federalism and the Stability and Growth Pact: A Difficult Union," Working Paper (Bank of Italy).

Bird, R. M., 1999, "Rethinking Tax Assignment: The Need for Better Subnational Taxes," mimeo.

Bordignon, M. and N. Emiliani, 1999, "Federalismo e perequazione in Italia, a proposito dell'articolo 10 della legge 133/1999," Rapporto preparato per il Consiglio Nazionale dell'Economia e del Lavoro, Roma, September 1999.

Corte dei Conti, 1999, Relazione sulla gestione finanziara delle regioni a statuto ordinario per l'anno 1997 (Roma).

CrSP, 1999, "L'Alliocazione delle Risorse nel Servizio Sanitario Nazionale," Commissione Tecnica per la Spesa Pubblica, Ministero del Tesoro, del Bilancio e della Programmazione Economica.

Emiliani, N., S. Lugaresi, and E. Ruggiero, 1997, "Italy," in Fiscal Federalism, ed. by T. TerMinassian, pp. 249-284.

Giarda, P., 2000, "Il federalismo fiscale in attuazione della legge n. 133/1999: aspetti tecnici. ragioni e problemi aperti," revised version, January 2, 2000.

Norregaard, J., 1997, "Tax assignment," in Fiscal Federalism, ed. by T. Ter-Minassian, pp. $49-72$.

OECD, 1994, "The Reform of Health Care Systems. A Review of Seventeen OECD Countries," Health Policy Studies No. 5 (OECD).

Pintus, E., 2000, "Government Reform in Italy," Working Papers (Joint Program IndesEuropean Union, Inter-American Development Bank).

Putnam, R. D., 1993, Making democracy Work: Civic Traditions in Modern Italy (Princeton: Princeton University Press).

Reviglio, F., 2000, "A System in Need of Reform: Health Care in Italy," mimeo, (Washington: International Monetary Fund). 
SVIMEZ, 2000, I Conti Economici delle Regioni Italiane dal 1970 al 1998 (I1 Mulino).

Tanzi, V., 1995, "Fiscal Federalism and Decentralization: A Review of Some Efficiency and Macroeconomic Aspects," Annual Bank Conference on Development Economics, The World Bank, Washington, D.C., May 1995.

Tanzi, V., A. Premchand, B. Potter, S. Lugaresi, and D. Demekas, 1994, "Italy: The Management of Public, Spending," IMF Fiscal Affairs Department.

Ter-Minassian, T., ed., 1997, Fiscal Federalism, (Washington: International Monetary Fund) 


\section{SOURCES OF DATA AND GENHRAL INFORMATION ON THE WORLD-WDE WEB}

A considerable amount of statistical and general information on Italy's economy athd legal as well as regulatory environment is available on the world-wide web. Listed below are key national and international sites. To the extent that data is not available directly on the sites, the sites provide references to additional publications.

\section{National Sources}

\section{Istituto Nazionale di Statistica}

hetp://www istatitit

Ministero del Tesoro, del Bilancio e della Programmazione Economica http:/Wwow tesoro it/

\section{Banca d'Italia}

http://www bancaditalia it

Commissione Nazionale per le Società e la Borsa

http / / whw consob.it/

Autorità Garante della Concorrenza e del Mercato

http:/Www agcm.it

Parlamento Italiano

http:/twrow.senato.it

2. International Sources

European Central Bank

http://wown eco int/

European Enion

http:/leuropa eu.int

Eurostat

http://europa.eu.int/en/comn/eurostat

International Monetary Fund

http//www.inforg/

http://dsbb,imforg/country/itacats.htm

Organisation for Economic Co-operation and Development http:/ orww oecd.org/ 